\title{
A degradation model for solid oxide fuel cell anodes due to impurities in coal syngas
}

\author{
Fatma Nihan Cayan \\ West Virginia University
}

Follow this and additional works at: https://researchrepository.wvu.edu/etd

\section{Recommended Citation}

Cayan, Fatma Nihan, "A degradation model for solid oxide fuel cell anodes due to impurities in coal syngas" (2010). Graduate Theses, Dissertations, and Problem Reports. 3001.

https://researchrepository.wvu.edu/etd/3001

This Dissertation is protected by copyright and/or related rights. It has been brought to you by the The Research Repository @ WVU with permission from the rights-holder(s). You are free to use this Dissertation in any way that is permitted by the copyright and related rights legislation that applies to your use. For other uses you must obtain permission from the rights-holder(s) directly, unless additional rights are indicated by a Creative Commons license in the record and/ or on the work itself. This Dissertation has been accepted for inclusion in WVU Graduate Theses, Dissertations, and Problem Reports collection by an authorized administrator of The Research Repository @ WVU.

For more information, please contact researchrepository@mail.wvu.edu. 


\title{
A DEGRADATION MODEL FOR SOLID OXIDE FUEL CELL ANODES DUE TO IMPURITIES IN COAL SYNGAS
}

\author{
Fatma Nihan Cayan \\ Dissertation submitted to the \\ College of Engineering and Mineral Resources \\ at West Virginia University \\ in partial fulfillment of the requirements \\ for the degree of \\ Doctor of Philosophy \\ in \\ Mechanical Engineering \\ Ismail Celik, Ph.D., Chair \\ Nigel Clark, Ph.D. \\ Harry Finklea, Ph.D. \\ Randall Gemmen, Ph.D. \\ Nianqiang $\mathbf{W u}$, Ph.D.
}

Department of Mechanical and Aerospace Engineering

\section{Morgantown, West Virginia \\ 2010}

Keywords: Solid Oxide Fuel Cells, Coal Syngas, Equilibrium, Degradation Modeling, Surface Reactions, Multi-Component Diffusion

Copyright 2010 Fatma Nihan Cayan 


\section{ABSTRACT}

\section{A DEGRADATION MODEL FOR SOLID OXIDE FUEL CELL ANODES DUE TO IMPURITIES IN COAL SYNGAS}

\section{Fatma Nihan Cayan}

Solid Oxide Fuel Cells (SOFCs) offer great promise as a clean and efficient alternative to conventional power generation technologies. A major advantage of SOFCs in comparison to other fuel cell types is that they can be operated directly on a wide variety of fuels including biogas, hydrocarbon fuels and coal-derived synthesis gas (syngas). SOFC operating on coal syngas is an especially attractive prospect given the abundant coal resources in the world. However, coal syngas usually contains various impurities such as phosphorus, arsenic, zinc, sulfur, mercury, selenium, and vanadium which affect the performance and durability of SOFCs. At low impurity concentrations, degradation rates are quite slow and long term experiments (more than $1000 \mathrm{~h}$ ) are required in order to determine the cell degradation rates accurately. Theoretical models that can predict the degradation behavior of SOFCs operating on syngas with very low levels of impurities could substantially reduce the time and effort involved in durability experiments.

In an attempt to predict the typical degradation patterns observed in Solid Oxide Fuel Cell (SOFC) anodes due to coal syngas contaminants such as arsenic (As) and phosphorous (P), a new phenomenological model is formulated. The model includes gas phase diffusion including Knudsen diffusion and surface diffusion within the anode and the adsorption reactions on the surface of the Ni-YSZ based anode. Model parameters such as reaction rate constants for the adsorption reactions are obtained through indirect calibration to match the degradation rates reported in the literature for arsine $\left(\mathrm{AsH}_{3}\right)$, phosphine $\left(\mathrm{PH}_{3}\right)$, hydrogen sulfide $\left(\mathrm{H}_{2} \mathrm{~S}\right)$ and hydrogen selenide $\left(\mathrm{H}_{2} \mathrm{Se}\right)$ under accelerated testing conditions. Current simulation results from implementation of the model demonstrated that the deposition of the impurity on the Ni catalyst starts near the fuel channel/anode interface and slowly moves toward the active anode/electrolyte interface which is in good agreement with the experimental data. Parametric studies performed at different impurity concentrations and operating temperatures showed that the coverage rate increases with increasing temperature and impurity concentration, as expected.

The calibrated model was then used for prediction of the performance curves at different impurity concentrations and operating temperatures. Encouraging agreement was obtained between the predicted results and the experimental data reported in the literature. Synergistic effect of various impurities including $\mathrm{AsH}_{3}, \mathrm{PH}_{3}$ and $\mathrm{H}_{2} \mathrm{~S}$ was also 
examined and it was concluded that the mixture of impurities leads to faster degradation and thus shorter lifetime of the cell when compared to that of a single impurity. 
To my only sunshine

Canım Oğlum’a 


\section{ACKNOWLEDGEMENTS}

First and foremost, I wish to express my deepest gratitude to my advisor, Dr. Ismail Celik for his guidance and encouragement throughout this study. I appreciate all his contributions of time, ideas and funding to make my Ph.D. experience productive and stimulating. His knowledge, wisdom and hard work have provided as an excellent example for me during these years. Special thanks are due to the other members in my graduate committee; Dr. Randall Gemmen, Dr. Harry Finklea, Dr. Nigel Clark and Dr. Nick $\mathrm{Wu}$ for taking time from their busy schedule to review my work and provide guidance with their insightful questions. I am also grateful to United States Department of Energy (USDOE), National Energy Technology Laboratory (NETL), West Virginia EPSCoR program and West Virginia University for funding this work. I want to thank my M.Sc. advisor Dr. Nevin Selcuk who has introduced me to the field of numerical modeling.

I also thank to the research team members for their friendship and support during my study: Dr. Raju Pakalapati, Dr. Jaggu Nanduri, Dr. Alejandro Posada, Yasemin Vural, Ertan Karaismail, Don Parsons, Francisco Elizalde, Fito Pino, John Redrow, Jose Escobar and Sergio Escobar for good times we had together. Special thanks to Raju for his outstanding help and patience to my never ending questions.

Special thanks to my parents Asuman and Omer Faruk Cayan and my sister Neval Cayan for their great support, encouragement and unshakable faith in me although they are thousands of miles away.

Lastly, I want to express my incommensurable love to my husband Ertan Karaismail, my soul mate, for his understanding, endless patience and encouragement when it was most required. And most of all, final thanks go to my son Dağhan Ali Karaismail, who made me a better person. 


\section{TABLE OF CONTENTS}

ABSTRACT ......................................................................................................... ii

ACKNOWLEDGEMENTS ................................................................................. v

TABLE OF CONTENTS ............................................................................... vi

LIST OF FIGURES ............................................................................. viii

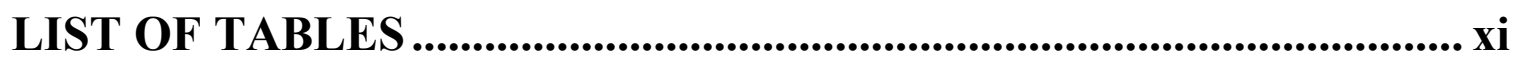

NOMENCLATURE.................................................................................... xii

CHAPTER 1- INTRODUCTION ............................................................ 1

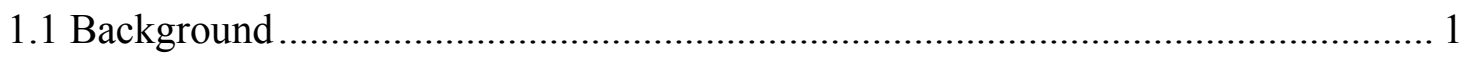

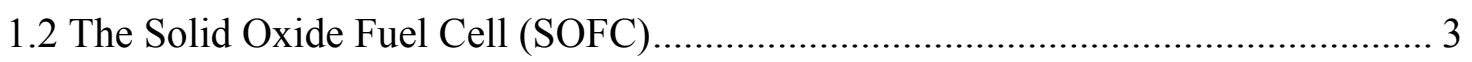

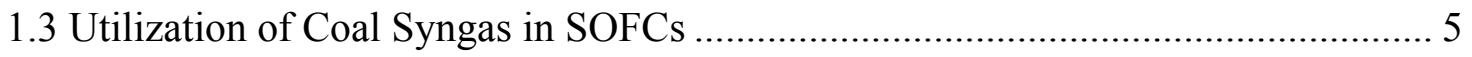

CHAPTER 2 - LITERATURE REVIEW ..................................................... 9

2.1 Effects of Coal Syngas Impurities on SOFCs........................................................... 9

2.2 Thermodynamic Equilibrium Calculations............................................................ 11

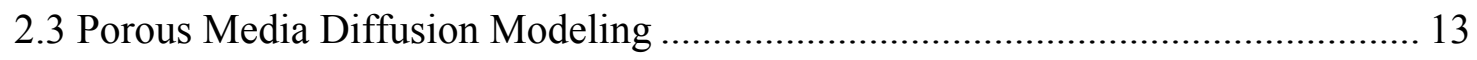

2.4 SOFC Anode Degradation Modeling.................................................................. 15

2.5 Objective and Goals ..................................................................................... 17

\section{CHAPTER 3- THERMODYNAMIC EQUILIBRIUM}

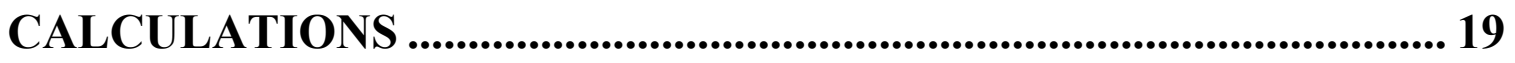

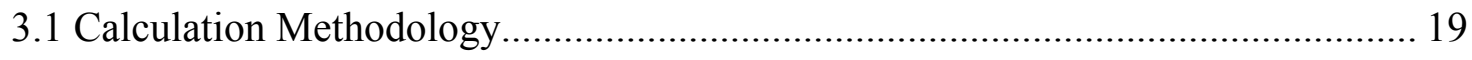

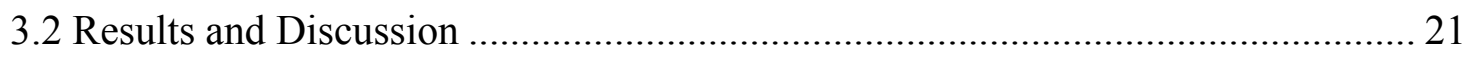

3.2.1 Gas Phase Equilibrium Calculations.......................................................... 21

3.2.2 Multiphase Equilibrium Calculations ............................................................ 25

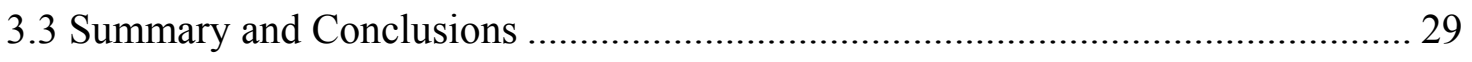

\section{CHAPTER 4- MULTI-COMPONENT DIFFUSION INSIDE POROUS}

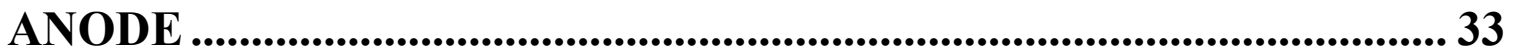

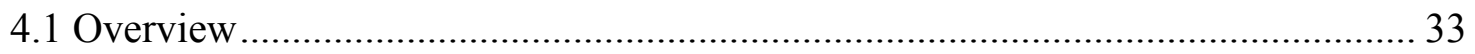




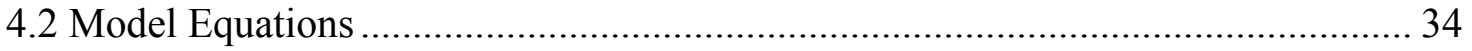

4.3 Numerical Solution Method.......................................................................... 38

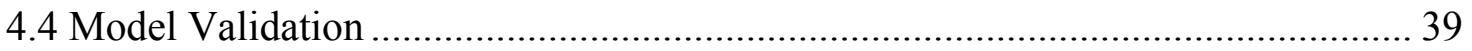

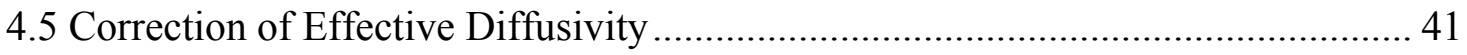

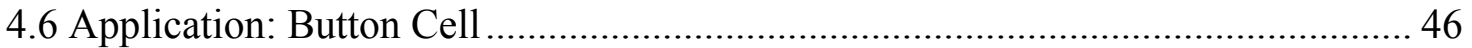

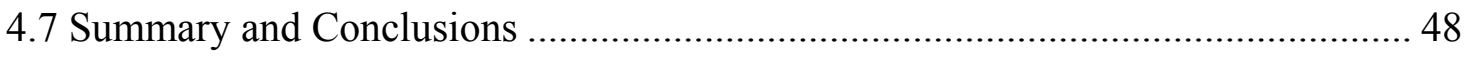

CHAPTER 5- IMPURITY DEGRADATION MODEL ......................... 49

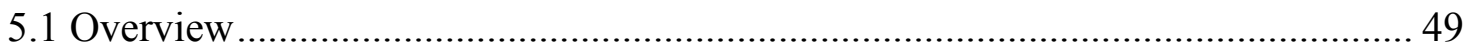

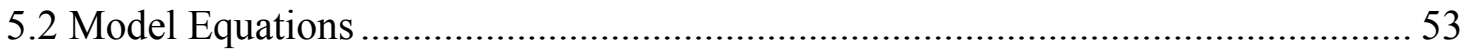

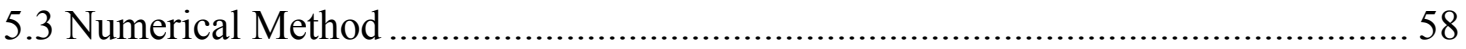

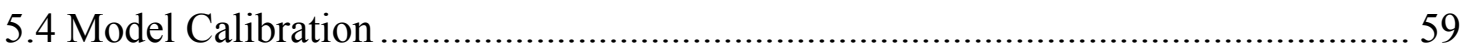

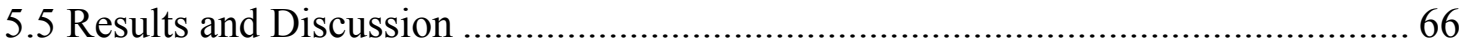

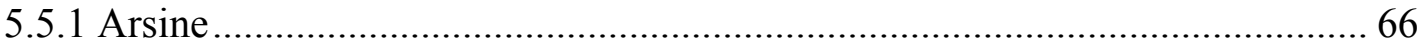

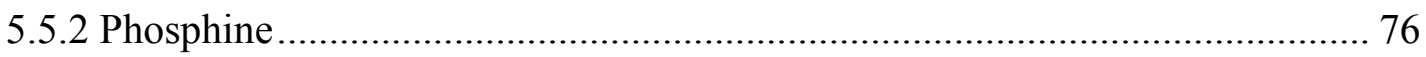

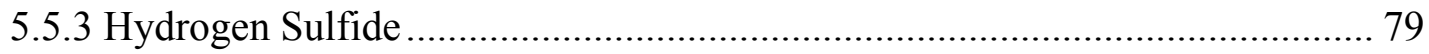

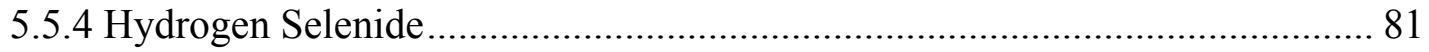

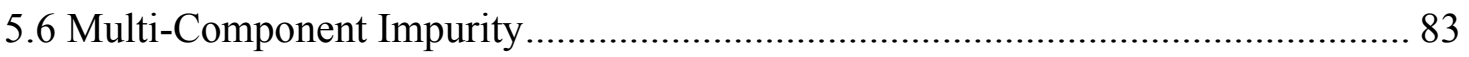

5.6.1 Arsine and Phosphine Mixture ................................................................... 85

5.6.2. Arsine and Hydrogen Sulfide Mixture......................................................... 88

5.6.3 Phosphine and Hydrogen Sulfide Mixture....................................................... 91

5.6.4 Arsine Phosphine and Hydrogen Sulfide Mixture ........................................... 93

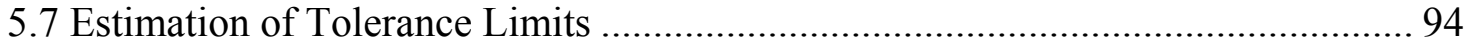

\section{CHAPTER 6- CONCLUSIONS AND RECOMMENDATIONS .......... 99}

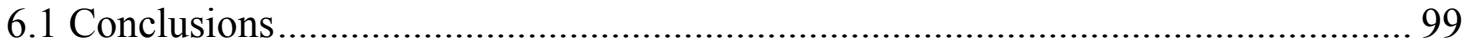

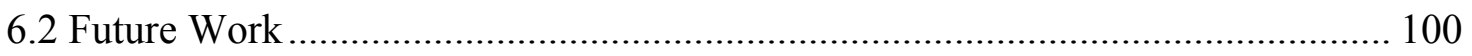

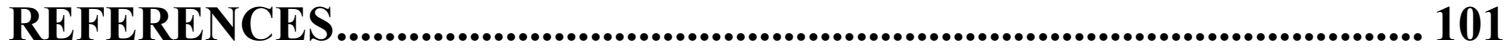

APPENDIX A

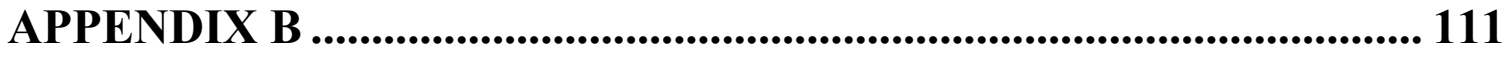




\section{LIST OF FIGURES}

Figure 1. 1: Common Fuel Cell types .............................................................................. 2

Figure 1. 2: Operation of solid oxide fuel cell ........................................................ 4

Figure 3. 1: Phase diagram showing the equilibrium concentration (ppm) of phosphorous containing species in coal syngas as a function of the initial $\mathrm{PH}_{3}$ concentration and the system temperatures for (a) without thermodynamic data of $\mathrm{HPO}_{2}$, (b) including thermodynamic data of $\mathrm{HPO}_{2}$

Figure 3. 2: Effect of pressure on nickel to nickel phosphide conversion at different initial $\mathrm{PH}_{3}$ concentrations at $750{ }^{\circ} \mathrm{C}$ and $0.5 \mathrm{amp}$..... 30

Figure 3. 3: Effect of current at different temperatures to nickel to nickel phosphide conversion for $15 \mathrm{ppm}$ initial concentration of $\mathrm{PH}_{3}$ at 1 atm 31

Figure 4. 1: Schematic representation of the SOFC anode

Figure 4. 2: Comparison between the molar rate of formation results of the present study and those of [35] 40

Figure 4. 3: Maximum percentage difference of Fick's model versus current density for (a) reactants, (b) products

Figure 4. 4: Concentration profiles along the anode thickness predicted by FM and SMM for (a)CO, (b) $\mathrm{H}_{2},(\mathrm{c}) \mathrm{CO}_{2}$ and $(\mathrm{d}) \mathrm{H}_{2} \mathrm{O}$ at $1 \mathrm{~A} / \mathrm{cm}^{2}$

Figure 4. 5: Concentration profiles along the anode thickness predicted by FM and SMM

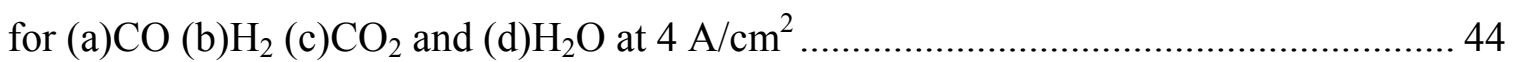

Figure 4. 6: Experimental and numerically simulated VI curves for the button cell

Figure 5. 1: Penetration thickness after $990 \mathrm{~h}$ with 1, 2, 5 and $10 \mathrm{ppm} \mathrm{of} \mathrm{PH}_{3}$ in coal syngas ([21], used with permission from PNNL)

Figure 5. 2: Typical degradation curve for $1 \mathrm{ppm} \mathrm{H}_{2} \mathrm{Se}$ in coal syngas at $700{ }^{\circ} \mathrm{C}[81] \ldots 51$

Figure 5. 3: Effect of Thiele modulus on the interface coverage for the impurity X. 61 
Figure 5. 4: Effect of Thiele modulus on the modified power density for the impurity $X$.

Figure 5. 5: Effect of Thiele modulus on the anode surface concentration of impurity $X 63$ Figure 5. 6: Effect of Thiele modulus on the impurity flux at the anode/fuel channel interface. 64

Figure 5. 7: Variation of performance degradation with model parameters (a) m, (b) n.. 65

Figure 5. 8: Calibration of modified power density against experimental data adopted from Coyle et al. [22] for $10 \mathrm{ppm} \mathrm{AsH}_{3}$ in coal syngas at $800{ }^{\circ} \mathrm{C}$ 67

Figure 5. 9: Time evolution of the interface coverage for $\mathrm{AsH}_{3}$ impurity........................ 68

Figure 5. 10: Coverage profile for $\mathrm{AsH}_{3}$ at different times ............................................ 69

Figure 5. 11: Porosity profile at different times.......................................................... 70

Figure 5. 12: Electrical conductivity profile at different times....................................... 70

Figure 5. 13: Time evolution of the exchange current density for $\mathrm{AsH}_{3}$ impurity ........... 71

Figure 5. 14: Effect of including cathode losses to performance degradation calculations

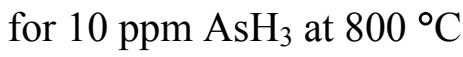
72

Figure 5. 15: Penetration thicknesses at $800{ }^{\circ} \mathrm{C}$ (a) for $10 \mathrm{ppm} \mathrm{AsH}_{3}$ in coal syngas after 2 h, $4 \mathrm{~h}, 6 \mathrm{~h}$ and $8 \mathrm{~h}$ of operation (b) after $10 \mathrm{~h}$ with 1, 5 and $10 \mathrm{ppm} \mathrm{AsH}_{3}$ in coal syngas 73 Figure 5. 16: Validation of the calibrated arsine degradation model for (a) concentration effect (b) temperature effect. 74

Figure 5. 17: Comparison between the modified power density predictions obtained by keeping the current constant at $0.05 \mathrm{~A} / \mathrm{cm}^{2}$ and keeping the current constant at $0.7 \mathrm{~V} \ldots 75$

Figure 5. 18: Calibration of modified power density against experimental data adopted from Marina et al. [23] for $5 \mathrm{ppm} \mathrm{PH}_{3}$ in coal syngas at $800{ }^{\circ} \mathrm{C}$...................................... 76

Figure 5. 19: Time evolution of the interface coverage for $\mathrm{PH}_{3}$ impurity ....................... 78 Figure 5. 20: Validation of the calibrated phosphine degradation model for concentration effect 79

Figure 5. 21: Calibration of modified power density against experimental data adopted from Xu [84] for $20 \mathrm{ppm} \mathrm{H}_{2} \mathrm{~S}$ in wet $\mathrm{H}_{2}$ at $800{ }^{\circ} \mathrm{C}$ 80

Figure 5. 22: Time evolution of the interface coverage for $\mathrm{H}_{2} \mathrm{~S}$ impurity 80

Figure 5. 23: Calibration of modified power density against experimental data adopted from Marina et al. [21] for $1.5 \mathrm{ppm} \mathrm{H}_{2} \mathrm{Se}$ in coal syngas at $800{ }^{\circ} \mathrm{C}$ 
Figure 5. 24: Time evolution of the interface coverage for $1.5 \mathrm{ppm} \mathrm{H}_{2} \mathrm{Se}$ impurity 83

Figure 5. 25: Comparison of performance loss for a mixture of $5 \mathrm{ppm} \mathrm{AsH}_{3}$ and $5 \mathrm{ppm}$

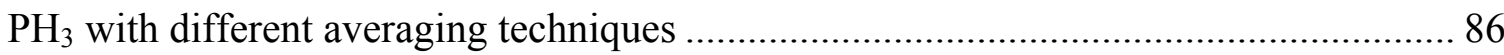

Figure 5. 26: Time evolution of interface coverages for 5 ppm $\mathrm{AsH}_{3}$ and 5 ppm $\mathrm{PH}_{3} \ldots 87$

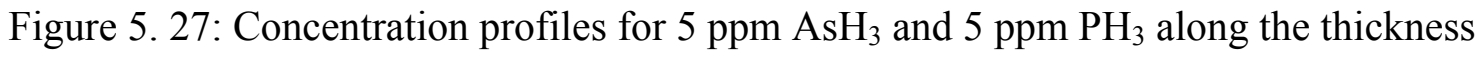
of the anode at $\mathrm{t}=20 \mathrm{~h}$ 88

Figure 5. 28: Comparison of performance loss for a mixture of $5 \mathrm{ppm} \mathrm{AsH}_{3}$ and $5 \mathrm{ppm}$ $\mathrm{H}_{2} \mathrm{~S}$ with different averaging techniques 89

Figure 5. 29: Time evolution of interface coverages for 5 ppm $\mathrm{AsH}_{3}$ and $5 \mathrm{ppm}_{2} \mathrm{~S} \ldots .90$

Figure 5. 30: Concentration profiles for $5 \mathrm{ppm} \mathrm{AsH}_{3}$ and $5 \mathrm{ppm}_{2} \mathrm{~S}$ along the thickness of the anode at $\mathrm{t}=20 \mathrm{~h}$ 90

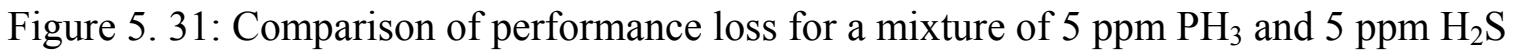

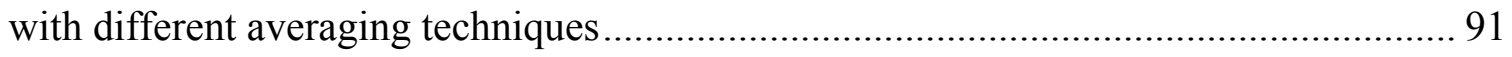

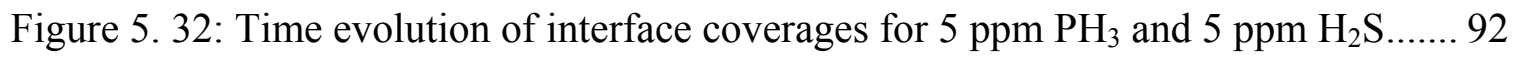

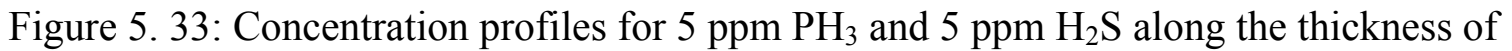
the anode at $\mathrm{t}=50 \mathrm{~h}$

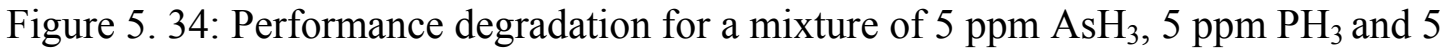
ppm $\mathrm{H}_{2} \mathrm{~S}$

Figure 5. 35: Time to cell failure for electrolyte-supported cells exposed to simulated coal syngas with varying concentrations of arsine at different operating temperatures. 95

Figure 5. 36: Time to cell cells exposed to simulated coal syngas with $10 \mathrm{ppm}$ of $\mathrm{AsH}_{3}$ coal syngas at $800^{\circ} \mathrm{C}$ with varying anode thicknesses

Figure 5. 37: Time to cell failure for electrolyte-supported cells exposed to simulated coal syngas with varying concentrations of phosphine at $800{ }^{\circ} \mathrm{C}$ 


\section{LIST OF TABLES}

Table 1. 1: Syngas compositions generated by different gasifiers (vol \%) [7] .................. 7

Table 1. 2: Trace impurities and their concentration in coal syngas [8] .......................... 8

Table 2. 1: Status of trace impurity species in a coal gas stream [32] .......................... 12

Table 3. 1: Coal syngas composition used for the equilibrium analysis under warm gas

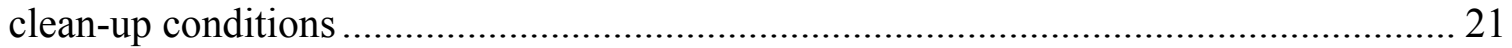

Table 3. 2: Trace species composition used for the equilibrium analysis under warm gas

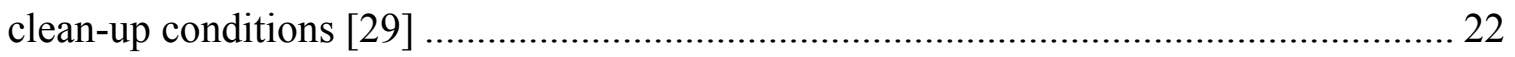

Table 3. 3: Possible forms of trace species in coal syngas at warm gas clean-up conditions (200-500 ${ }^{\circ} \mathrm{C}$ and $\left.1 \mathrm{~atm}\right)$

Table 3. 4: Equilibrium composition of phosphorus-containing species at $900^{\circ} \mathrm{C}$ and 1.0

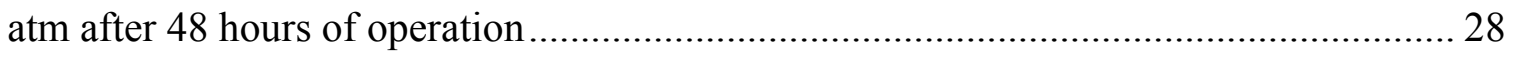

Table 4. 1: Parameters used for comparison ................................................................... 39

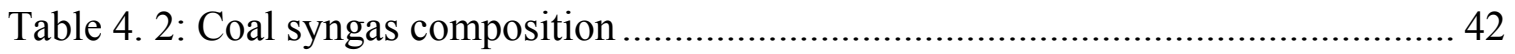

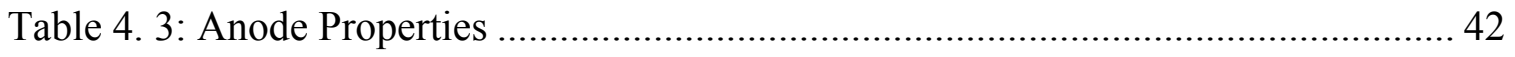

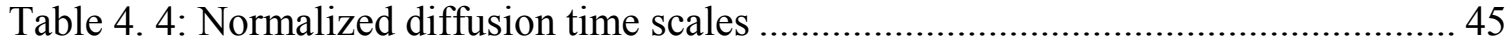

Table 4. 5: Normalized reaction time scales ................................................................. 45

Table 4. 6: Fuel composition supplied to the anode ................................................... 46

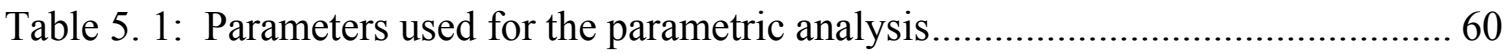

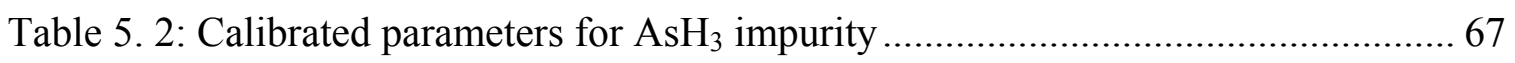

Table 5. 3: Calibrated parameters for $\mathrm{PH}_{3}$ impurity …............................................... 77

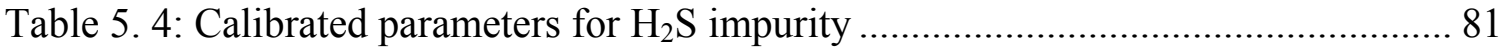

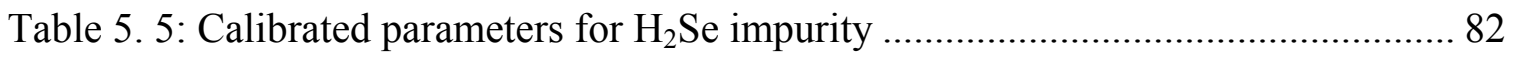




\section{NOMENCLATURE}

As

$\mathrm{a}_{\mathrm{s}}$

$\mathrm{Be}$

c

$\mathrm{Cd}$

$\mathrm{Cl}$

$\mathrm{Cr}$

$D_{\theta}$

$D_{i}^{k}$

$D_{i j}$

$D_{i}^{k^{*}}$

$D_{i j}^{*}$

$E_{a c t, i}$

$E_{N}$

F

G

$\mathrm{Hg}$

i

$i_{\text {ref }}$

$i_{o}$

K

$k_{r}^{+}$

$k_{r}^{-}$

$k_{s}^{+}, k_{s}^{-}$ arsenic

specific catalyst area, $\mathrm{m}^{-1}$

beryllium

diffusivity model parameter

cadmium

chlorine

chromium

transport coefficient, $\mathrm{m}^{2} \mathrm{~s}^{-1}$

Knudsen diffusivity, $\mathrm{m}^{2} \mathrm{~s}^{-1}$

binary diffusivity, $\mathrm{m}^{2} \mathrm{~s}^{-1}$

effective Knudsen diffusivity, $\mathrm{m}^{2} \mathrm{~s}^{-1}$

effective binary diffusivity, $\mathrm{m}^{2} \mathrm{~s}^{-1}$

activation energy barrier, $\mathrm{J}_{\text {mole }}{ }^{-1}$

Nernst potential, $\mathrm{V}$

Faraday's constant, $\mathrm{C}$ mole ${ }^{-1}$

Gibbs function, $\mathrm{J}_{\text {mole }}{ }^{-1}$

mercury

total current density, $\mathrm{A} \mathrm{m}^{-2}$

reference current density, $\mathrm{A} \mathrm{m}^{-2}$

exchange current density, $\mathrm{A} \mathrm{m}^{-2}$

potassium

forward reaction rate constant for methane steam reforming reaction, $\mathrm{mol} \mathrm{m}^{-3} \mathrm{~s}^{-1} \mathrm{~Pa}^{-2}$

backward reaction rate constant for methane steam reforming reaction, mol m $\mathrm{m}^{-3} \mathrm{~s}^{-1} \mathrm{~Pa}^{-4}$ forward and backward reaction rate constants for water gas shift reaction, $\mathrm{mol} \mathrm{m} \mathrm{m}^{-3} \mathrm{~s}^{-1} \mathrm{~Pa}^{-2}$ 


\begin{tabular}{|c|c|}
\hline$k_{f, H}, k_{b, H}$ & $\begin{array}{l}\text { forward and backward reaction rate constants } \\
\text { for hydrogen adsorption, } \mathrm{s}^{-1}\end{array}$ \\
\hline$k_{f, X}, k_{b, X}$ & $\begin{array}{l}\text { forward and backward reaction rate constants } \\
\text { for contaminant } X \text { adsorption, } \mathrm{s}^{-1}\end{array}$ \\
\hline$k_{m}$ & mass transfer coefficient, $\mathrm{m} \mathrm{s}^{-1}$ \\
\hline$M_{i}$ & molecular weight of, $\mathrm{g} \mathrm{mole}^{-1}$ \\
\hline$M_{a v g}$ & average molecular weight, $\mathrm{g} \mathrm{mole}^{-1}$ \\
\hline $\mathrm{m}$ & degradation model parameter \\
\hline$n$ & diffusivity model parameter \\
\hline $\mathrm{n}$ & degradation model parameter \\
\hline $\mathbf{n}$ & vector of mole fractions \\
\hline$N_{i}$ & molar flux, mole $\mathrm{m}^{-2} \mathrm{~s}^{-1}$ \\
\hline $\mathbf{N}$ & stoichiometric matrix \\
\hline $\mathrm{Na}$ & sodium \\
\hline$P$ & pressure of the system, $\mathrm{Pa}$ \\
\hline D & phosphorous \\
\hline$P$ & power density, Watt $\mathrm{m}^{-2}$ \\
\hline$P^{*}$ & modified power density \\
\hline $\mathrm{Pb}$ & lead \\
\hline $\mathrm{p}$ & degradation model parameter \\
\hline $\mathrm{q}$ & degradation model parameter \\
\hline$R_{u}$ & universal gas constant, $\mathrm{J} \mathrm{mol}^{-1} \mathrm{~K}^{-1}$ \\
\hline$R_{i}$ & $\begin{array}{l}\text { molar production rate of species } i \text { due to } \\
\text { homogenous reactions, mole } \mathrm{m}^{-3} \mathrm{~s}^{-1}\end{array}$ \\
\hline$\langle r\rangle$ & mean pore diameter, $\mu \mathrm{m}$ \\
\hline $\mathrm{Sb}$ & antimony \\
\hline $\mathrm{Se}$ & selenium \\
\hline$S h$ & Sherwood number \\
\hline$S_{i}$ & $\begin{array}{l}\text { net production rate of species } i \text { due to surface } \\
\text { reactions, mole } \mathrm{m}^{-3} \mathrm{~s}^{-1}\end{array}$ \\
\hline
\end{tabular}




$\begin{array}{ll}T & \text { temperature of the system, } \mathrm{K} \\ \mathrm{t} & \text { time, } \mathrm{s} \\ \mathrm{V} & \text { vanadium } \\ X, Y & \text { Typical contaminant } \\ y_{i} & \text { mole fractions } \\ \mathrm{Zn} & \text { zinc }\end{array}$

\section{Greek}

$\begin{array}{ll}\alpha & \text { transfer coefficient } \\ \delta & \text { anode thickness, } \mathrm{m} \\ \varepsilon & \text { porosity } \\ \varepsilon_{0} & \text { porosity at zero percent contaminant coverage } \\ \phi & \text { electrical potential, } \mathrm{V} \\ \eta_{i} & \text { overpotentials, } \mathrm{V} \\ \Gamma & \text { site density, mol } \mathrm{m}^{-2} \\ \mu & \text { vector of species chemical potentials } \\ \Pi & \text { Thiele modulus } \\ \theta_{i} & \text { surface coverages } \\ \sigma & \text { electrical conductivity, } \mathrm{S} \mathrm{m}{ }^{-1} \\ \sigma_{0} & \text { electrical conductivity at zero percent } \\ & \text { contaminant coverage, } \mathrm{S} \mathrm{m} \mathrm{m}^{-1} \\ v_{i} & \text { tortuosity } \\ \omega_{\theta_{i}} & \text { stoichiometric coefficient } \\ & \text { source terms due to surface adsorption } \\ & \text { extent of reaction }\end{array}$




\section{CHAPTER 1- INTRODUCTION}

\subsection{Background}

Modern lifestyles have resulted in increasing levels of energy consumption. To supply the demand for the ever increasing levels of the energy, traditional power generation techniques including combustion of fossil fuels have been widely used over the last century. Coal is the most abundant, readily available and economical fossil fuel in the world. At current production levels, proven coal reserves are estimated to last approximately 225 years [1]. However, an undesirable consequence of coal combustion is environmental contamination, as a result of the combustion by-products released to the atmosphere. Moreover, coal combustion is not an efficient way to generate electrical power, since burning coal to produce steam for electrical power production is limited by the Carnot Cycle Efficiency.

Fuel cells appear to be an attractive alternative to traditional power generation methods. A fuel cell is a device that generates electricity by combining a fuel and an oxidant electrochemically, rather than thermochemically, as is the case with the conventional fossil fuel combustion. Electrochemical power generation has many advantages over fossil fuel combustion, including higher efficiency, low pollution and low equipment maintenance. The fuel cell receives the reactants that take place in the energy conversion process in a continuous manner, unlike batteries, which use chemical energy that is stored within the electrodes. Since the first demonstration of the fuel cell principle by Sir William Grove in 1839 [2], many types of fuel cells, namely Alkaline Fuel Cell, Proton 
Exchange Membrane (PEM) Fuel Cell, Direct Methanol (DM) Fuel Cell, Phosphoric Acid (PA) Fuel Cell, Molten Carbonate (MC) Fuel Cell, Solid Oxide Fuel Cell (SOFC) have been developed. Figure 1.1 shows the summary of the most common fuel cell types.

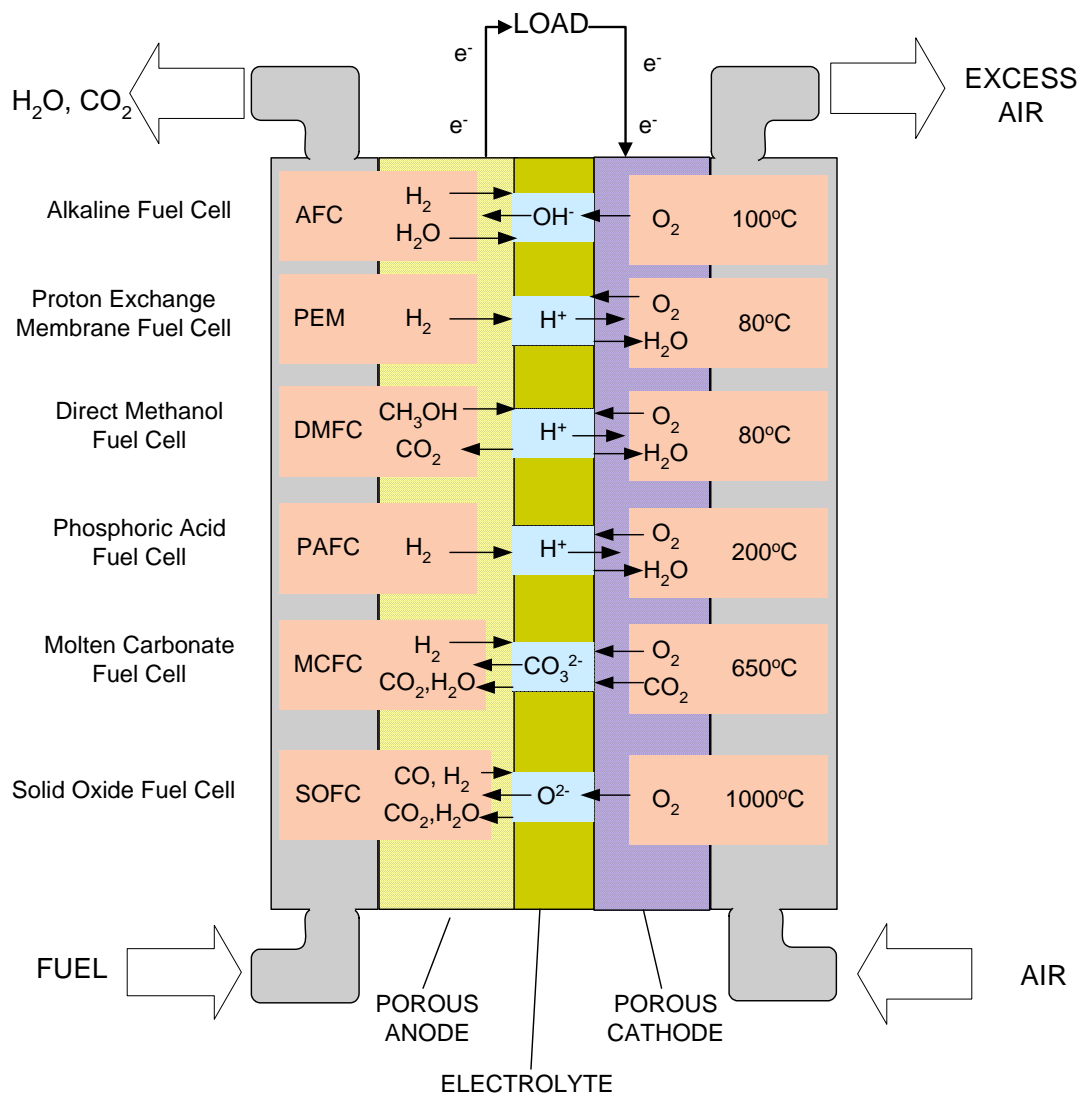

Figure 1. 1: Common Fuel Cell types

Among them, Solid Oxide Fuel Cells (SOFCs) have become one of the most viable candidates for future power plants due to their high efficiency and fuel flexibility. 


\subsection{The Solid Oxide Fuel Cell (SOFC)}

The SOFC is a high temperature fuel cell that has many advantages as an energy conversion device, especially for stationary applications. The main components of a fuel cell are the electrolyte and the electrodes. The electrolyte of an SOFC is an ionically conducting ceramic membrane that prevents direct combination of the fuel and the oxidant. This membrane is sandwiched between two porous, electronically (or mixed) conducting electrodes: the anode on the fuel side and the cathode on the air side.

The electrolyte is a dense, gas-tight ceramic layer, traditionally made of yttria-stabilized zirconia (YSZ), which is a good conductor of oxide ions, $\mathrm{O}^{2-}$. An electronically conductive, gas tight interconnect plate provides the series connection of unit cells constituting an SOFC stack.

Since ionic conductivity in ceramics is a thermally activated process, high operating temperatures are required to obtain sufficient overall conductivity in the fuel cell. YSZ exhibits acceptable conductivity above $600^{\circ} \mathrm{C}$. The oxide ion, $\mathrm{O}^{2-}$, allows the use of a variety of fuels other than hydrogen, such as carbon monoxide or any hydrocarbon fuel, either by direct oxidation or through steam reforming. Another important feature of the high operating temperature is the possibility to use the exhaust heat in a power generating bottoming cycle, using either a gas or steam turbine. These features give the SOFC great versatility compared to other fuel cell types, as well as creating the possibility of generating electrical power at very high efficiencies. On the other hand, the elevated operation temperature requires long start-up periods.

The porous anode made of a composite nickel/yttria-stabilized zirconia (Ni/YSZ) is catalytically active for the oxidation reaction and retains sufficient ionic as well as electronic conductivities. Similarly, the porous cathode made of lanthanum manganite $\left(\mathrm{LaMnO}_{3}\right)$ doped with strontium ( $\left.\mathrm{Sr}\right), \mathrm{LSM}$, is able to catalyze dissociation of oxygen and has good electronic conductivity in the presence of air. There are three basic designs of the SOFCs are available: cathode-, electrolyte- and anode-supported. 
For electricity generation in SOFCs, oxygen molecules in the cathode pores dissociate at the surface of the catalyst (e.g. LSM) and combine with free electrons coming from the external circuit, and the resulting oxide ions move through the electrolyte toward the anode. In the anode, the oxide ions combine with hydrogen, carbon monoxide or hydrocarbon molecules to form $\mathrm{H}_{2} \mathrm{O}$ and $\mathrm{CO}_{2}$. The electrons released in the oxidation reaction have to escape through an external circuit, creating usable electricity and closing the loop. Figure 1.2 depicts schematically the case of hydrogen and carbon monoxide being used as a fuel in an SOFC.

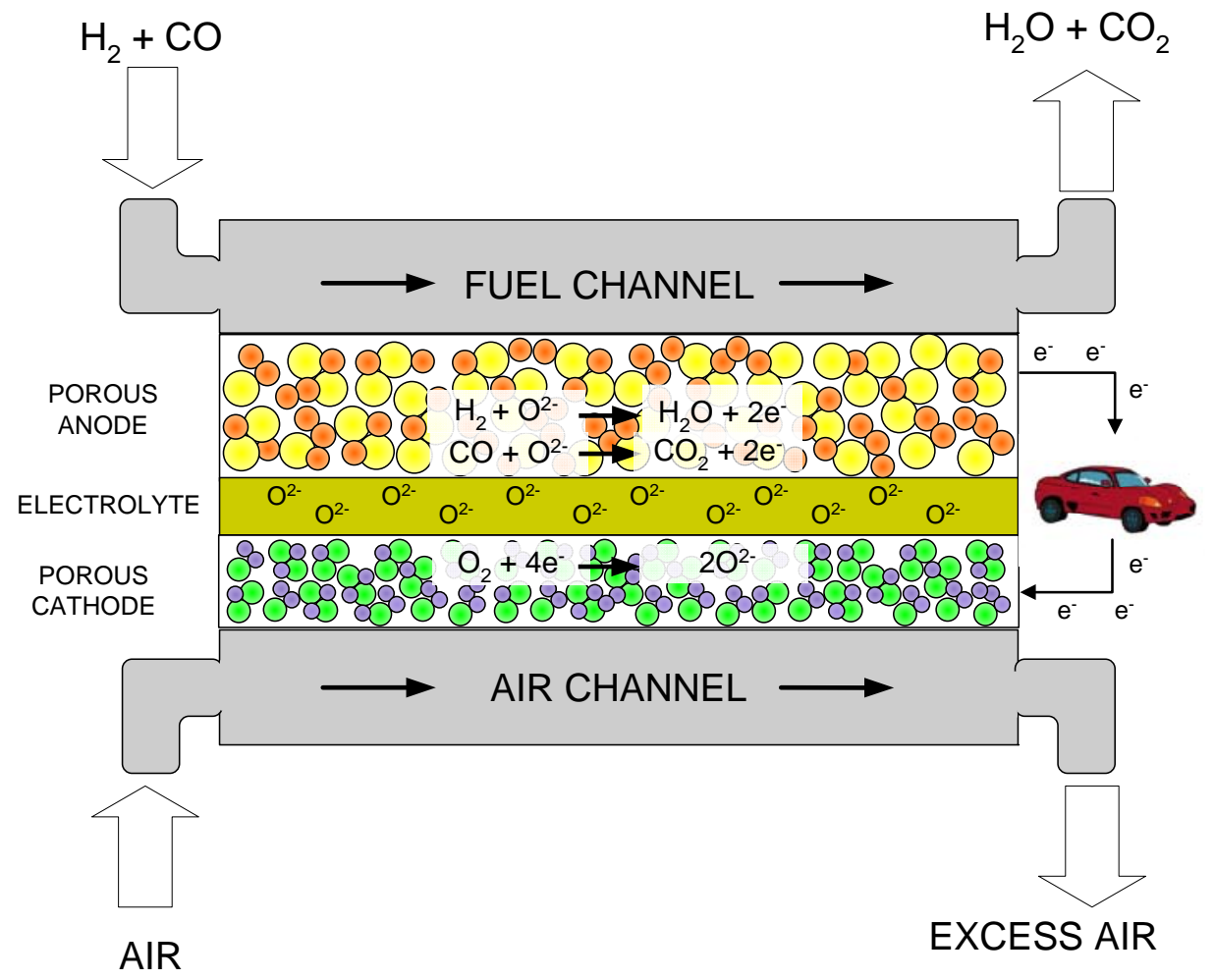

Figure 1. 2: Operation of solid oxide fuel cell

A unit cell generates approximately $1 \mathrm{~V}$ at open circuit conditions, with exact voltage depending on temperature, oxygen partial pressure, and reactant and product concentrations. This value is commonly known as open circuit voltage, or OCV. While operating, the delivered voltage is smaller than the OCV due to irreversible losses or cell 
polarization. Polarization has been classified as activation, ohmic and concentration [3]. The activation polarization arises due to slow rate of electrochemical reactions. The ohmic polarization is a result of electrical resistance in the cell including ionic resistance to the flow of ions in the electrolyte and electronic resistance to the flow of electrons in the rest of the cell components. The concentration polarization is a resistance due to the mass transfer limitations in supplying reactants to the electrochemical reaction sites.

\subsection{Utilization of Coal Syngas in SOFCs}

Coal syngas is produced via a process called coal gasification in which coal is mixed with an oxidant $\left(\mathrm{O}_{2}\right.$ or air) and steam in a reactor operating under the pressure of 24-70 atm at $500 \sim 1800{ }^{\circ} \mathrm{C}$ to produce syngas containing carbon monoxide $(\mathrm{CO})$, hydrogen $\left(\mathrm{H}_{2}\right)$, carbon dioxide $\left(\mathrm{CO}_{2}\right)$, water vapor $\left(\mathrm{H}_{2} \mathrm{O}\right)$, methane $\left(\mathrm{CH}_{4}\right)$ and nitrogen $\left(\mathrm{N}_{2}\right)$ and also trace amounts of nearly all of the naturally occurring elements depending on the rank and geographical origin of the coal $[4,5]$. Oxygen blown gasification is often used since less combustion of coal is needed to heat the reactants and less work is needed to compress the gases entering the reactor [5]. Moreover, oxygen blown gasification will help enable future $\mathrm{CO}_{2}$ sequestration techniques [6]. Three types of coal gasification systems have been used throughout industry; namely, moving bed, fluid bed, and entrained flow. Table 1.1 shows the compositions of the raw syngas derived from these three major gasification systems [7]. The product syngas composition is extremely dependent on the coal as well as the gasification process. Table 1.2 shows trace impurities and their concentrations in the coal syngas generated by the gasification stream of Eastman Chemical Company's complex at Kingsport Tennessee and an estimate from University of North Dakota Energy and Environmental Research Center [8].

The combination of a coal gasifier with a SOFC not only provides clean energy by reducing the emissions but also may help reduce plant costs because high efficiency electrochemical systems should result in smaller physical plant size for a given electric power output as compared to conventional electricity generation techniques. Although recent studies have shown the feasibility of fueling SOFC systems with coal syngas [9- 
11], the performance and the durability of SOFCs are affected by the presence of the impurity species in coal syngas. When a Ni-YSZ anode is operated in the impuritycontaining syngas, the impurities may affect

- the mass transport of fuel gas molecules due to adsorption of the impurities on the anode surface forming secondary phases with the anode material to cause morphological changes via grain coarsening and consequent blockage of gas diffusion channels,

- the catalytic ability of $\mathrm{Ni}$ toward chemical and electrochemical reactions since impurity atoms on the surface poison (deactivate) triple phase boundaries,

- the ability of YSZ to transport the oxygen ions by forming other phases (zirconium silicate or phosphate are theoretically possible),

- the electrical conductivity of Ni by forming Ni alloys,

- the conductivity of interconnect-anode interface, and,

- the structural integrity of the Ni-YSZ anode and seal materials

The above material interactions may also affect other material properties, such as thermal conductivity, porosity and modulus of elasticity which, in turn, may lead to performance degradation. The effect of trace impurity species on the performance of SOFC anodes must be measured in order to (i) determine the required level for removal of these species from coal syngas before reaching the anode and (ii) to develop new anode materials that resist the attack of these undesired poisoning effects. Although it is possible to produce ultra-clean syngas by cleanup techniques, the cost of reducing the concentration of all potentially harmful impurities to sub-ppm levels will be very high.

The impact of major impurities, such as sulfur and carbon on the Ni-YSZ anode has been studied by researchers and the results are available in the literature [12-14]. However, the short term and long term effects of trace impurities like arsenic, phosphorus, selenium, chlorine and antimony on the SOFC performance are still unclear. 
Table 1. 1: Syngas compositions generated by different gasifiers (vol \%) [7]

\begin{tabular}{|c|c|c|c|c|c|c|c|}
\hline Gasifier Type & Moving- & Fluidized & & Entrai & ed-Bed & & \\
\hline Manufacturer & Lurgi & Winkler & Destec & $\begin{array}{c}\text { Koppers- } \\
\text { Totzek }\end{array}$ & Texaco & Shell & Siemens \\
\hline \multirow{2}{*}{ Coal } & Illinois & Texas & Appalachian & Illinois & \multicolumn{2}{|c|}{ Illinois Illinois } & \\
\hline & No.6 & Lignite & Bit. & No.6 & No.6 & No.6 & \\
\hline \multicolumn{8}{|l|}{ Mole Percent } \\
\hline $\mathrm{Ar}$ & trace & 0.7 & 0.8 & 0.9 & 0.9 & 1.1 & \\
\hline $\mathrm{CH}_{4}$ & 3.3 & 4.6 & 0.6 & - & 0.1 & - & 0.002 \\
\hline $\mathrm{C}_{2} \mathrm{H}_{4}$ & 0.1 & - & - & - & - & - & - \\
\hline $\mathrm{C}_{2} \mathrm{H}_{6}$ & 0.2 & - & - & - & - & - & - \\
\hline $\mathrm{CO}$ & 5.8 & 33.1 & 45.2 & 43.8 & 39.6 & 63.1 & 27.001 \\
\hline $\mathrm{CO}_{2}$ & 11.8 & 15.5 & 8.0 & 4.6 & 10.8 & 1.5 & 1.770 \\
\hline $\mathrm{COS}$ & trace & - & - & 0.1 & - & 0.1 & 0.037 \\
\hline $\mathrm{H}_{2}$ & 16.1 & 28.3 & 33.9 & 21.1 & 30.3 & 26.7 & 13.211 \\
\hline $\mathrm{H}_{2} \mathrm{O}$ & 61.8 & 16.8 & 9.8 & 27.5 & 16.5 & 2.0 & 53.165 \\
\hline $\mathrm{H}_{2} \mathrm{~S}$ & 0.5 & 0.2 & 0.9 & 1.1 & 1.0 & 1.3 & 0.421 \\
\hline $\mathrm{N}_{2}$ & 0.1 & 0.6 & 0.6 & 0.9 & 0.7 & 4.1 & 4.375 \\
\hline $\mathrm{NH}_{3}+\mathrm{HCN}$ & 0.3 & 0.1 & 0.2 & - & - & - & 0.006 \\
\hline
\end{tabular}


Table 1. 2: Trace impurities and their concentration in coal syngas [8]

\begin{tabular}{|c|c|c|}
\hline Contaminant & $\begin{array}{c}\text { Concentration at the } \\
\text { Kingsport Facility } \\
\text { (ppmv) }\end{array}$ & $\begin{array}{c}\text { UND-EERC } \\
\text { Estimate }\end{array}$ \\
\hline Arsine $\left(\mathrm{AsH}_{3}\right)$ & 0.15 to 0.58 & 0.2 \\
\hline Thiophene & & 1.6 \\
\hline Chlorine (Cl) & & 120 \\
\hline Methyl Fluoride $\left(\mathrm{CH}_{3} \mathrm{~F}\right)$ & 2.6 & \\
\hline Methyl Chloride $\left(\mathrm{CH}_{3} \mathrm{Cl}\right)$ & 2.01 & \\
\hline Hydrogen Chloride ( $\mathrm{HCl})$ & $<1$ & \\
\hline $\mathrm{Fe}(\mathrm{CO})_{5}$ & 0.05 to 5.6 & \\
\hline $\mathrm{Ni}(\mathrm{CO})_{5}$ & 0.001 to 0.025 & \\
\hline $\mathrm{CH}_{3} \mathrm{SCN}$ & 2.1 & \\
\hline Phosphine $\left(\mathrm{PH}_{3}\right)$ & 1.9 & \\
\hline Antimony (Sb) & 0.025 & 0.07 \\
\hline Cadmium (Cd) & & 0.01 \\
\hline Chromium (Cr) & $<0.025$ & 6.0 \\
\hline Mercury (Hg) & $<0.025$ & 0.002 \\
\hline Selenium (Se) & $<0.15$ & 0.17 \\
\hline Vanadium (V) & $<0.025$ & \\
\hline Lead $(\mathrm{Pb})$ & & 0.26 \\
\hline Zinc (Zn) & 9.0 & \\
\hline
\end{tabular}




\section{CHAPTER 2 - LITERATURE REVIEW}

\subsection{Effects of Coal Syngas Impurities on SOFCs}

Given the fact that coal is the most abundant and readily available fossil fuel in the world, it will continue to play a significant role as an energy source for many years to come. With the rising concern about the effect of coal combustion by-products, such as greenhouse gases, on the environment, many countries are pursuing efforts to develop more sustainable energy systems to replace conventional boilers. Solid Oxide Fuel Cells (SOFCs) offer great promise as a clean and efficient alternative [15]. A major advantage of the SOFCs in comparison to other fuel cell types is that it can be operated directly on a wide variety of fuels including $\mathrm{H}_{2}$, biogas, hydrocarbon fuels and coal-derived synthesis gas (syngas) [15]. Although recent studies have shown the feasibility of fueling SOFC systems with coal syngas [9-11], the performance and the durability of SOFCs are affected by the presence of the certain impurity species such as phosphorus (P), arsenic (As), zinc $(\mathrm{Zn})$, sulfur $(\mathrm{S})$, mercury $(\mathrm{Hg})$, selenium (Se), and vanadium (V), commonly found in the fuel stream which are found to react with the SOFC anode materials. It is difficult to completely remove these impurities and the clean-up processing is very expensive. Therefore, it is imperative that fuel cells be tolerant to these impurities up to a certain level. 
Bao et al. [16] investigated the effect of several impurities including $\mathrm{As}_{2}, \mathrm{HPO}_{2}, \mathrm{Cd}$, $\mathrm{CH}_{3} \mathrm{Cl}, \mathrm{HCl}, \mathrm{Hg}, \mathrm{SbO}$ and $\mathrm{Zn}$ in a simulated coal-derived syngas on SOFC performance at the temperatures ranging from $750^{\circ} \mathrm{C}$ to $850^{\circ} \mathrm{C}$. Impurities were tested at relatively high concentration levels and short exposure duration, i.e., accelerated testing conditions. Of the contaminants tested, arsenic and phosphorus species degraded the performance rapidly. Both of these species resulted in a severe decrease in the observed cell power density with time of exposure. The As vapor species reacted with the Ni current collector in the anode to form nickel arsenides such as $\mathrm{Ni}_{5} \mathrm{As}_{2}$ causing electrical connectivity problems and eventually, cell failure. The phosphorus-species reacted with $\mathrm{Ni}$ to form nickel phosphides such as $\mathrm{Ni}_{3} \mathrm{P}$ and also reacted with $\mathrm{YSZ}$ to form zirconium phosphates. The presence of $\mathrm{CH}_{3} \mathrm{Cl}$ and $\mathrm{Cd}$ in fuel stream resulted in performance loss at temperatures above $800^{\circ} \mathrm{C}$ and significant power density loss was observed with $5 \mathrm{ppm}$ $\mathrm{Cd}$ at $850^{\circ} \mathrm{C}$. In order to determine the synergistic effects of presence of multiple contaminants in the fuel stream, Bao et al. [17] also performed tests with coal syngas containing mixtures of $\mathrm{H}_{2} \mathrm{~S}+\mathrm{AsH}_{3}, \mathrm{H}_{2} \mathrm{~S}+\mathrm{PH}_{3}$, or $\mathrm{H}_{2} \mathrm{~S}+\mathrm{AsH}_{3}+\mathrm{PH}_{3}+\mathrm{CH}_{3} \mathrm{Cl}$ each at about 1 ppm level. It was concluded that, the cell exposed to $\mathrm{PH}_{3}+\mathrm{H}_{2} \mathrm{~S}$ mixture degraded somewhat more rapidly than a similar cell that was exposed to $\mathrm{PH}_{3}$ alone. Similar results were also observed when a cell was exposed to syngas containing $\mathrm{AsH}_{3}$ and $\mathrm{H}_{2} \mathrm{~S}$.

Recently, Trembly et al. [18-20] studied the effect of trace levels of $\mathrm{HCl}, \mathrm{AsH}_{3}, \mathrm{PH}_{3}$, and $\mathrm{H}_{2} \mathrm{Se}$ on the performance of solid oxide fuel cell anodes. The authors observed an immediate but reversible performance loss up to $50 \%$ when the electrolyte-supported cells were exposed to 20 and $160 \mathrm{ppm} \mathrm{HCl}$ in coal syngas at 800 and $900^{\circ} \mathrm{C} \mathrm{[19].} \mathrm{The}$ authors observed little degradation for $\mathrm{AsH}_{3}$ concentrations less than or equal to $2 \mathrm{ppm}$ during $100 \mathrm{~h}$ of testing at 750 and $800^{\circ} \mathrm{C}$ [18]. Although $\mathrm{PH}_{3}$ after $100 \mathrm{~h}$ exposure did not affect the fuel cell performance at $5 \mathrm{ppm}$ level, formation of a secondary $\mathrm{Ni}_{3} \mathrm{P}$ phase was observed at the anode [20]. Anode supported cells exposed to $\mathrm{H}_{2} \mathrm{Se}$ at $5 \mathrm{ppm}$ levels showed an immediate degradation at $750^{\circ} \mathrm{C}[20]$.

Marina et al.[21] and Coyle et al.[22] also reported that $\mathrm{PH}_{3}$ and $\mathrm{AsH}_{3}$ cause severe degradation in the performance of both anode and electrolyte supported SOFCs at ppm 
levels. Irreversible degradation was observed for $\mathrm{PH}_{3}$ at 0.5 to $10 \mathrm{ppm}$ levels in coal syngas at 700 to $800^{\circ} \mathrm{C}$ due to bulk nickel phosphide phase formation [23]. Investigation of performance of SOFC in coal syngas containing $0-10 \mathrm{ppm} \mathrm{AsH}_{3}$ at $700-800^{\circ} \mathrm{C}$ revealed that the performance loss was due to formation of secondary nickel arsenide phases creating a sharp boundary between the converted and unconverted portions of the anode [22].

Researchers at West Virginia University [24-27] have also investigated the effect of $\mathrm{PH}_{3}$ and $\mathrm{HCl}$ on the performance of Ni-YSZ anode. Zhi et al. [27] exposed Ni-YSZ half cells to $20 \mathrm{ppm} \mathrm{PH}_{3}$ in coal syngas. After $48 \mathrm{~h}$ of exposure, the morphology of the Ni-YSZ anode surface significantly changed leading to a reduction in the porosity. Further XRD analysis has revealed that phosphorus has reacted with $\mathrm{Ni}$ and $\mathrm{Zr}$, leading to the formation of $\mathrm{Ni}_{3}(\mathrm{PO})_{4}$ and $\mathrm{ZrP}_{2} \mathrm{O}_{7}$. Dramatic and irreversible performance loss of anodesupported SOFC due to $10 \mathrm{ppm} \mathrm{PH}_{3}$ in coal syngas via formation of $\mathrm{Ni}_{5} \mathrm{P}_{2}$ phase formations was observed by Xu et al. [25]. Xu et al. [24] also reported a steady and irreversible power loss of $3 \%$ over $400 \mathrm{~h}$ at 800 and $850^{\circ} \mathrm{C}$ for anode-supported cells exposed to $100 \mathrm{ppm} \mathrm{HCl}$ in coal syngas.

\subsection{Thermodynamic Equilibrium Calculations}

Thermodynamic equilibrium calculations have been performed by several researchers [28-31] to predict the stable forms of the trace elements found inherently in typical coal syngas. The exact identity of the species proceeding from the gasifier to the fuel cell depends primarily on the starting coal composition, the gasifier design and the syngas cleanup technology used. These studies provide useful information in determining which species will form condensed phases and can easily be filtered before entering the SOFC [29] and which of them pose a potential to produce secondary phases with the anode material. However, it is still a point of debate whether or not equilibrium calculations are reliable for such applications given the fact that the equilibrium composition varies widely with respect to the thermodynamic database utilized [21]. 
Trembly et al. [29] conducted a thermodynamic equilibrium analysis to determine the effect of warm gas cleanup system conditions on the trace species partitioning between the vapor and the condensed phases and to identify the form of impurity species in coal syngas. The analysis was carried in two steps: cleanup stage analysis (CSA) and anode reaction analysis (ARA). Results showed that $\mathrm{Be}, \mathrm{Cr}, \mathrm{K}, \mathrm{Na}$, and $\mathrm{V}$ trace species form condensed phases under warm gas cleanup conditions and should be removed efficiently before reaching the SOFC anode. The authors also reported that antimony, arsenic, cadmium, lead, mercury, phosphorus, zinc and selenium trace species form vapor phase species and of special interest are antimony, arsenic and phosphorus which have the potential to form secondary phases with Ni in the SOFC anode.

Krishnan et al. [32] also performed thermodynamic equilibrium calculations using gas streams representative of an oxygen-blown slugging gasifier. Table 2.1 lists the predicted chemical forms and partitioning of the trace species at different temperature ranges [32].

Table 2. 1: Status of trace impurity species in a coal gas stream [32]

\begin{tabular}{|c|c|c|c|c|}
\hline Component & $>1000^{\circ} \mathrm{C}$ & $400-800{ }^{\circ} \mathrm{C}$ & $100-400{ }^{\circ} \mathrm{C}$ & $<100^{\circ} \mathrm{C}$ \\
\hline As & $\mathrm{AsO}, \mathrm{As}_{2}$ & $\mathrm{AsO}, \mathrm{As}_{4}$ & $\mathrm{As}_{2}$ & $\mathrm{AsH}_{3}$ \\
\hline $\mathrm{Be}$ & $\mathrm{Be}(\mathrm{OH})_{2}$ & Condensed species & Condensed Species & Condensed Species \\
\hline $\mathrm{Hg}$ & $\mathrm{Hg}$ & $\mathrm{Hg}$ & $\mathrm{Hg}, \mathrm{HgCl}_{2}$ & $\mathrm{Hg}, \mathrm{HgCl}_{2}$ \\
\hline B & $\mathrm{HBO}$ & $\mathrm{HBO}$ & $\mathrm{HBO}$ & - \\
\hline $\mathrm{V}$ & $\mathrm{VO}_{2}$ & Condensed species & Condensed species & Condensed species \\
\hline $\mathrm{Se}$ & $\mathrm{H}_{2} \mathrm{Se}, \mathrm{Se}, \mathrm{SeO}$ & $\mathrm{H}_{2} \mathrm{Se}$ & $\mathrm{H}_{2} \mathrm{Se}$ & $\mathrm{H}_{2} \mathrm{Se}$ \\
\hline $\mathrm{Ni}$ & $\mathrm{NiCl}, \mathrm{NiCl}_{2}$ & Condensed species & $\mathrm{Ni}(\mathrm{CO})_{4}$ & $\mathrm{Ni}(\mathrm{CO})_{4}$ \\
\hline $\mathrm{Co}$ & $\mathrm{CoCl}_{2}, \mathrm{CoCl}$ & Condensed species & Condensed species & Condensed species \\
\hline $\mathrm{Sb}$ & $\mathrm{SbO}, \mathrm{Sb}_{2}$ & $\mathrm{SbO}, \mathrm{Sb}_{2}$ & $\mathrm{Sb}_{4}$ & Condensed species \\
\hline $\mathrm{Cd}$ & $\mathrm{Cd}$ & $\mathrm{Cd}$ & $\mathrm{CdCl}_{2}$ & Condensed species \\
\hline $\mathrm{Pb}$ & $\mathrm{Pb}, \mathrm{PbCl}_{2}$ & $\mathrm{PbS}, \mathrm{Pb}, \mathrm{PbCl}_{2}$ & Condensed species & Condensed species \\
\hline $\mathrm{Zn}$ & $\mathrm{Zn}$ & $\mathrm{Zn}, \mathrm{ZnCl}_{2}$ & Condensed species & Condensed species \\
\hline
\end{tabular}


As can be seen from Table 2.1, although the results may vary with the coal and operating conditions of the gasifier, under cold gas clean up conditions $\left(<100{ }^{\circ} \mathrm{C}\right) \mathrm{Be}, \mathrm{V}, \mathrm{Co}, \mathrm{Sb}$, $\mathrm{Cd}, \mathrm{Pb}$ and $\mathrm{Zn}$ impurity species will form condensed phases and can be removed efficiently. However, under warm/hot gas clean up conditions $\left(>250^{\circ} \mathrm{C}\right), \mathrm{Sb}, \mathrm{Cd}, \mathrm{Pb}$ and $\mathrm{Zn}$ trace species will form vapor phase species and may not be captured by the filters. These impurities have a potential to interact with the SOFC anode.

Recently, Martinez et al.[33] performed an extensive thermodynamic analysis to examine the effect of impurities found in coal syngas derived from 15 different gasifiers on SOFC anode material. They have also performed the calculations in two steps, namely CSA and ARA, as Trembly et al. [29]. Results showed that Cr, V, Zn, Be and Se trace species partition to liquid or solid phases at CSA and thus can be easily filtered whereas $\mathrm{Pb}, \mathrm{S}$, $\mathrm{Cd}, \mathrm{Sb}, \mathrm{Cl}$ trace species partitioned between the gas and liquid/solid phases and has a potential to proceed from the gasifier to the SOFC anode. Of those gas phase species As, $\mathrm{P}$ and $\mathrm{Sb}$ demonstrates a propensity to form secondary phases with $\mathrm{Ni}$ anode.

\subsection{Porous Media Diffusion Modeling}

Diffusion transport inside the porous medium has two components: bulk molecular diffusion where molecular to molecular interaction dominates the transport and Knudsen diffusion where molecular to solid wall interaction dominates the transport. Several different approaches have been developed to evaluate multi-component porous media transport. Ackmann et al. [34] investigated mass transport in SOFC cathodes and anodes using a Mean Transport Pore Model (MTPM). Their work showed that for typical SOFC anode operating on reformed methane syngas, neglecting Knudsen diffusion or permeation can result in deviations up to $20 \%$.

Lehnert et al. [35] modeled the effect of methane-derived syngas on anode performance to determine the effect of anode structural properties on methane conversion. The model considered molecular, Knudsen, and convective transport via the MTPM, and included 
the Water Gas Shift (WGS) and Methane Steam Reforming (MSR) reactions. The kinetics for the MSR and WGS were determined experimentally by Drescher et al. [36] . The results from this model showed that porosity and pore size have the most significant control (5-12\%) over methane conversion.

Haberman and Young [37] investigated the transport of methane-derived syngas in a 1 $\mathrm{mm}$ thick porous SOFC anode. Their model used the Darcy equation to describe convective transport due to pressure gradients and the Stefan-Maxwell equation for bulk gas diffusion. Contributions from Knudsen diffusion was ignored due to an assumed large pore size of $10 \mu \mathrm{m}$. The model used the same fuel composition and reforming kinetics as Lehnert et al. [35]. Only hydrogen oxidation was considered. The results showed that for a case with reforming, little variation in species concentrations exist through the highly porous support. Results also showed an almost uniform hydrogen production rate in the direction of the thickness of the anode, which was higher at the inlet than the exit by nearly two orders of magnitude. The $\mathrm{H}_{2}$ production followed the temperature profile, which was also nearly uniform through the thickness of the anode, high at the inlet and significantly lower at the exit due to internal reforming.

Hecht et al. [38] used Dusty Gas Model (DGM) for the transport of species through a porous Ni/YSZ cermet, and included a detailed kinetic model for MSR. The authors compared results of the model to experimental results from a hardware configuration that approximated the conditions of a true SOFC. The model incorporated 42 separate reaction mechanisms to account for MSR, WGS, and species surface coverages. The comparison of the model results to experimental results showed overall good agreement in trends and species concentrations.

Gemmen and Trembly [39] investigated the detailed transport of coal syngas through porous Ni-YSZ anode of an SOFC using the Dusty Gas Model (DGM). Methane steam reforming and water gas shift reactions were considered to occur homogeneously inside the anode. A constant ratio of 4 between the currents produced from the electrochemical 
oxidations of $\mathrm{H}_{2}$ and $\mathrm{CO}$ was assumed. The analyses of operating pressure ranging from 1 to $15 \mathrm{~atm}$ revealed its effect on species profiles, diffusion losses and cell heating.

Suwanwarangkul et al. [40], compared Fick's, Dusty Gas and Stefan Maxwell Models for a simple one-dimensional case without bulk chemical reactions and recommended the use of Dusty Gas Model for multi-component systems which is the case for SOFC anodes Same group [41] also performed experimental and numerical study of an electrolyte supported SOFC operating on coal syngas. A two-dimensional isothermal model of a button SOFC was developed considering simultaneous electrochemical oxidation of $\mathrm{H}_{2}$ and $\mathrm{CO}$ by assuming a constant ratio between the currents produced from each of them and water gas shift reaction. Experimental and numerical results indicated that the lower performance of the cell is due to the carbon formation when operated on coal syngas.

\subsection{SOFC Anode Degradation Modeling}

While the experimental studies provide guidance on the identification of the impurities in coal syngas and their effects on the performance of Ni-yttria stabilized zirconia (Ni-YSZ) anode of SOFCs, tolerance limits for various impurities are not yet established. At low impurity concentrations, degradation rates are quite slow and long term experiments (more than $1000 \mathrm{~h}$ ) are required in order to determine the durability of the cell for a given concentration [20]. Models developed based on the knowledge base gained from short term experimental data at relatively higher concentrations can be used to estimate the degradation levels at any concentration and at any time.

There are only a few modeling studies that account for the effects of impurities in the syngas on the SOFC anode $[18,42,43]$. Effects of impurities are studied only for $\mathrm{H}_{2}$ fuel. Hansen [42] analyzed experimental data on sulfur's impact on SOFC anodes using an isotherm for the sulfur coverage on the $\mathrm{Ni}$ surface and proposed a linear relationship between the performance loss and the sulfur coverage. In another study, Zhang et al. [43] developed a model for the Pt-based catalyst poisoning induced by fuel impurities for 
PEM fuel cell. Although their model can be used to simulate and estimate the chemical and electrochemical reaction rate constants, and make some prediction about the severity of the contamination and the performance recoverability, it has not yet been validated against benchmark experimental data.

In addition to electrochemical performance, structural integrity of SOFC anode is essential for successful long-term operation. Anode-supported SOFCs, in particular, rely on anode cermet as structural support for electrolyte and cathode. SOFC anode is subjected to stresses at high temperature, thermal/redox cycles, and coal syngas contaminants effects during long-term operation. These mechanisms can alter anode microstructure and affect its electrochemical performance and structural properties. Sarantaridis and Atkinson [44] proposed a simplified mechanical model of the stress and damage that are likely to be caused by anode expansion due to redox cycle. The model is applied to anode-supported and electrolyte-supported cell configurations to estimate maximum oxidation strain to avoid damage in each configuration. Recently, Iqbal et al. [45] developed a durability model involving thermomechanical and fuel gas contaminant degradation mechanisms to predict the long term structural integrity of the SOFC anode. Model predictions indicated that thermomechanical degradation is greater at the anode/electrolyte interface and increases linearly with time and for the phosphine contaminant, the anode structural degradation starts at the exposed anode surface and penetrates towards the active interface.

Overall, there is a dearth in the literature for numerical models that can predict the long term electrochemical performance and durability of SOFCs exposed to fuels with impurities. In order to formulate remedies for the undesirable effects of these impurities, it is necessary to understand the underlying mechanisms through which the cell performance has deteriorated. 


\subsection{Objective and Goals}

The review presented in the previous section revealed that it is essential to establish maximum tolerance limits for potentially harmful impurity species and lifetime of cells at given impurity levels. Since at low impurity concentrations degradation rates are very slow and long term experiments of at least $1000 \mathrm{~h}$ are needed, it is practically impossible to establish these limits for tens of impurity species only by testing. The best possible remedy for this problem is to develop theoretical models that can accurately predict the degradation behavior by optimizing the knowledge base gained from short term testing at relatively higher concentrations. The objective of this study is to develop a physics and chemistry based, verified and validated theoretical model to predict the performance degradation of a SOFC anode due to various levels of impurities present in the coal syngas under a range of operating conditions. The model will provide us with the valuable information regarding the lifetime of the cells with minimum number of long term experiments. The specific goals of this work are to:

1. Use equilibrium calculations to predict the stable forms of impurity species at SOFC operating conditions and also to predict conversion of Ni to secondary phases as a function of time.

2. Formulate a simple yet accurate model for mass transport and heterogeneous reactions inside the Ni-YSZ based anode of an SOFC which includes gas phase diffusion, Knudsen diffusion and surface diffusion.

3. Include trace impurity species transport in the anode model using simple reaction mechanisms.

4. Develop phenomenological models to correlate the anode performance to transport of contaminants inside the anode and predict the performance of the SOFCs upon exposure to syngas contaminants.

5. Calibrate the empirical model parameters using experimental results from the literature. 
6. Perform parametric studies using the calibrated phenomenological model to predict the cell life times and tolerance levels of the impurities under various operating conditions. 


\section{CHAPTER 3- THERMODYNAMIC EQUILIBRIUM CALCULATIONS}

Thermodynamic equilibrium calculations provide a quantitative approach for determining the most stable forms of a system of chemical species. In this study, these calculations are performed specifically for identification of the stable forms of coal syngas impurities under SOFC conditions and their possible interactions with the anode material. In what follows calculation methodology and application to coal syngas impurities under SOFC conditions along with the results and conclusions are presented.

\subsection{Calculation Methodology}

In the present study, Cantera 1.7 [46], an open-source library of chemical kinetics and thermodynamic equilibrium subroutines, which is capable of solving multiphase equilibrium problems, was employed for calculations. For multiphase equilibrium computations, Cantera uses the Villars-Cruise-Smith (VCS) algorithm which solves the stoichiometric formulation of equilibrium conditions by minimizing the total Gibbs function of the system at the specified temperature and pressure with the constraint of non-negative molar concentrations $(\mathbf{n} \geq 0)$ [47]:

$G(\xi)=\mathbf{n}^{\top} \boldsymbol{\mu}=\left[\mathbf{n}^{0}+\mathbf{N} \xi\right]^{\top} \boldsymbol{\mu}$ 
Here $G$ and $\xi$ denote the total Gibbs function of the mixture and the extent of reaction vector, respectively. $\mathbf{n}$ is the vector of mole fractions, $\mathbf{N}$ is the stoichiometric matrix, $\boldsymbol{\mu}$ is the vector of species chemical potentials. The superscripts ' 0 ' and ' $T$ ' stand for initial condition and transpose, respectively. The details of the numerical procedure utilized in Cantera can be found in [47].

The equilibrium analysis was carried out in two parts. The first part, namely gas phase calculations, is aimed at determining the partitioning behavior of coal syngas impurities between the gas and condensed phases under warm gas cleanup conditions. These calculations also provided an implicit verification of the calculation procedure used in this study by comparing the predictions with those of Trembly et al [29]. As a separate analysis, the effect of SOFC operating conditions on the equilibrium status of phosphorous upon introduction of $\mathrm{PH}_{3}$ to the simulated coal syngas was also investigated on the gas phase system. In the second part of the study, namely multi-phase calculations, simulations are performed using simulated coal syngas with $\mathrm{PH}_{3}$ impurity including possible secondary Ni-P species expected to form between the phosphorous impurity and the Ni catalyst found in the anode.

All possible forms of the species in the gas phase and/or in the condensed phase were considered in the calculations. The gas phase species are assumed to obey the ideal gas law and the mixture is treated as an ideal mixture. The condensed phase species are assumed to be either stoichiometric solids or stoichiometric liquids. Thermodynamic data of these species are obtained from various resources available in the literature [48-51] and an extensive database of thermodynamic properties for various possible compounds of impurities and cell materials was compiled. 


\subsection{Results and Discussion}

\subsubsection{Gas Phase Equilibrium Calculations}

\subsubsection{Possible Forms of Trace Species in Coal Syngas}

In an attempt to determine the trace species that are likely to form and be transported to the SOFC anodes, equilibrium calculations were performed under warm gas cleanup conditions (200-500 ${ }^{\circ} \mathrm{C}$ and $\left.1 \mathrm{~atm}\right)$. All possible forms of the impurity species at the gas phase and the condensed phase were considered. Tables 3.1 and 3.2 tabulate the initial concentration of the coal syngas and the impurity species used for the analysis, respectively. These concentrations are representative of typical coal syngas (see Table 1.1 for compositions of the raw syngas derived from different types of gasifiers) and are same as those used by Trembly et al.[29]. Resulting forms of the impurity species are given in Table 3.3 for different temperatures.

Table 3. 1: Coal syngas composition used for the equilibrium analysis under warm gas clean-up conditions

\begin{tabular}{cc}
\hline Species & Composition (Vol \%) \\
\hline $\mathrm{CO}$ & 0.287 \\
$\mathrm{H}_{2} \mathrm{O}$ & 0.272 \\
$\mathrm{CO}_{2}$ & 0.118 \\
$\mathrm{H}_{2}$ & 0.293 \\
$\mathrm{~N}_{2}$ & 0.03 \\
\hline
\end{tabular}


Table 3. 2: Trace species composition used for the equilibrium analysis under warm gas clean-up conditions [29]

\begin{tabular}{cc}
\hline Species & Composition (ppm) \\
\hline $\mathrm{AsH}_{3}$ & 0.600 \\
$\mathrm{PH}_{3}$ & 1.910 \\
$\mathrm{Sb}$ & 0.070 \\
$\mathrm{Cd}$ & 0.011 \\
$\mathrm{Be}$ & 0.025 \\
$\mathrm{Cr}$ & 6.00 \\
$\mathrm{Hg}$ & 0.025 \\
$\mathrm{Se}$ & 0.150 \\
$\mathrm{Na}$ & 320.0 \\
$\mathrm{~V}$ & 0.025 \\
$\mathrm{~Pb}$ & 0.260 \\
$\mathrm{Zn}$ & 9.00 \\
\hline
\end{tabular}


Table 3. 3: Possible forms of trace species in coal syngas at warm gas clean-up conditions $\left(200-500{ }^{\circ} \mathrm{C}\right.$ and $\left.1 \mathrm{~atm}\right)$

\begin{tabular}{|c|c|c|c|c|c|}
\hline Species & $200^{\circ} \mathrm{C}$ & $300^{\circ} \mathrm{C}$ & $400^{\circ} \mathrm{C}$ & $500^{\circ} \mathrm{C}$ & $800^{\circ} \mathrm{C}$ \\
\hline Arsenic & $\begin{array}{l}\operatorname{As}(\mathrm{s}) \\
\mathrm{As}_{4}(\mathrm{~g})\end{array}$ & $\mathrm{As}_{4}(\mathrm{~g}), \mathrm{AsH}_{3}(\mathrm{~g})$ & $\begin{array}{c}\mathrm{As}_{4}(\mathrm{~g}), \\
\mathrm{AsH}_{3}(\mathrm{~g}), \\
\mathrm{As}_{3} \mathrm{Sb}(\mathrm{g})\end{array}$ & $\begin{array}{c}\mathrm{As}_{4}(\mathrm{~g}) \\
\mathrm{AsH}_{3}(\mathrm{~g}) \\
\mathrm{As}_{3} \mathrm{Sb}(\mathrm{g})\end{array}$ & $\begin{array}{l}\mathrm{As}_{4}(\mathrm{~g}) \\
\mathrm{AsH}_{3}(\mathrm{~g})\end{array}$ \\
\hline Phosphorous & $\mathrm{HPO}_{2}(\mathrm{~g})$ & $\mathrm{HPO}_{2}(\mathrm{~g})$ & $\mathrm{HPO}_{2}(\mathrm{~g})$ & $\mathrm{HPO}_{2}(\mathrm{~g})$ & $\mathrm{HPO}_{2}(\mathrm{~g})$ \\
\hline Antimony & $\mathrm{SbO}_{2} \mathrm{H}_{2}(\mathrm{~g})$ & $\mathrm{SbO}_{2} \mathrm{H}_{2}(\mathrm{~g})$ & $\mathrm{SbO}_{2} \mathrm{H}_{2}(\mathrm{~g})$ & $\mathrm{SbO}_{2} \mathrm{H}_{2}(\mathrm{~g})$ & $\mathrm{SbO}_{2} \mathrm{H}_{2}(\mathrm{~g})$ \\
\hline Cadmium & $\mathrm{CdS}(\mathrm{s}), \mathrm{CdSe}(\mathrm{s})$ & $\mathrm{Cd}(\mathrm{g}), \mathrm{CdSe}(\mathrm{s})$ & $\mathrm{Cd}(\mathrm{g})$ & $\mathrm{Cd}(\mathrm{g})$ & $\mathrm{Cd}(\mathrm{g})$ \\
\hline Beryllium & $\mathrm{BeO}(\mathrm{s})$ & $\mathrm{BeO}(\mathrm{s})$ & $\mathrm{BeO}(\mathrm{s})$ & $\mathrm{BeO}(\mathrm{s})$ & $\mathrm{BeO}(\mathrm{s})$ \\
\hline Chromium & $\left(\mathrm{Na}_{2} \mathrm{O}\right)\left(\mathrm{Cr}_{2} \mathrm{O}_{3}\right)(\mathrm{s})$ & $\left(\mathrm{Na}_{2} \mathrm{O}\right)\left(\mathrm{Cr}_{2} \mathrm{O}_{3}\right)(\mathrm{s})$ & $\mathrm{Cr}_{2} \mathrm{O}_{3}(\mathrm{~s})$ & $\mathrm{Cr}_{2} \mathrm{O}_{3}(\mathrm{~s})$ & $\mathrm{Cr}_{2} \mathrm{O}_{3}(\mathrm{~s})$ \\
\hline Mercury & $\mathrm{Hg}(\mathrm{g})$ & $\mathrm{Hg}(\mathrm{g})$ & $\mathrm{Hg}(\mathrm{g})$ & $\mathrm{Hg}(\mathrm{g})$ & $\mathrm{Hg}(\mathrm{g})$ \\
\hline Selenium & $\mathrm{CdSe}(\mathrm{s}), \operatorname{PbSe}(\mathrm{s})$ & $\mathrm{CdSe}(\mathrm{s}), \operatorname{PbSe}(\mathrm{s})$ & $\begin{array}{l}\mathrm{PbSe}(\mathrm{s}), \\
\mathrm{H}_{2} \mathrm{Se}(\mathrm{g}), \\
\mathrm{AsSe}(\mathrm{g})\end{array}$ & $\begin{array}{l}\mathrm{H}_{2} \mathrm{Se}(\mathrm{g}), \\
\text { AsSe }(\mathrm{g})\end{array}$ & $\mathrm{H}_{2} \mathrm{Se}(\mathrm{g})$ \\
\hline Sodium & $\left(\mathrm{Na}_{2} \mathrm{O}\right)\left(\mathrm{Cr}_{2} \mathrm{O}_{3}\right)(\mathrm{s})$ & $\mathrm{Na}_{2} \mathrm{CO}_{3}(\mathrm{~s})$ & $\mathrm{Na}_{2} \mathrm{CO}_{3}(\mathrm{~s})$ & $\mathrm{Na}_{2} \mathrm{CO}_{3}(\mathrm{~s})$ & $\mathrm{Na}_{2} \mathrm{CO}_{3}(\mathrm{~s})$ \\
\hline Vanadium & $\mathrm{V}_{2} \mathrm{O}_{3}(\mathrm{~s})$ & $\mathrm{V}_{2} \mathrm{O}_{3}(\mathrm{~s})$ & $\mathrm{V}_{2} \mathrm{O}_{3}(\mathrm{~s})$ & $\mathrm{V}_{2} \mathrm{O}_{3}(\mathrm{~s})$ & $\mathrm{V}_{2} \mathrm{O}_{3}(\mathrm{~s})$ \\
\hline Lead & $\mathrm{Pb}(\mathrm{s}), \mathrm{PbSe}(\mathrm{s})$ & $\mathrm{Pb}(\mathrm{s}), \mathrm{PbSe}(\mathrm{s})$ & $\begin{array}{c}\mathrm{Pb}(1) \\
\mathrm{PbSe}(\mathrm{s})\end{array}$ & $\begin{array}{c}\mathrm{Pb}(\mathrm{g}), \\
\mathrm{Pb}(\mathrm{l}), \\
\mathrm{PbSe}(\mathrm{s}), \\
\mathrm{PbSe}(\mathrm{g})\end{array}$ & $\begin{array}{c}\mathrm{Pb}(\mathrm{g}), \\
\mathrm{PbSe}(\mathrm{s}), \\
\mathrm{PbSe}(\mathrm{g})\end{array}$ \\
\hline Zinc & $\mathrm{ZnO}(\mathrm{s})$ & $\mathrm{ZnO}(\mathrm{s})$ & $\mathrm{ZnO}(\mathrm{s})$ & $\mathrm{ZnO}(\mathrm{s})$ & $\mathrm{ZnO}(\mathrm{s})$ \\
\hline
\end{tabular}

As can be seen from Table 3.3, trace species like beryllium, chromium, sodium, vanadium and zinc in coal syngas form condensed phases and can be removed efficiently before reaching SOFC anode whereas antimony, arsenic, cadmium, lead, mercury, phosphorus, zinc and selenium form vapor phase species can react with the anode material. These results conform with those of Trembly et al. [29]. The calculations were repeated at the anode operating conditions and the most stable forms of the impurity 
species are also listed in the Table 3.3. As can be seen from the table, antimony, arsenic, cadmium, lead, mercury, phosphorus, zinc and selenium form vapor phase species and have a potential to react with the anode material.

\subsubsection{Possible Forms of $\mathrm{PH}_{3}$ in Coal Syngas in the Gas Phase}

In addition to calculations at warm gas cleanup conditions, equilibrium calculations were also performed on the gas phase system to check the equilibrium status of phosphorous after $\mathrm{PH}_{3}$ was introduced into the simulated coal syngas containing $30.6 \% \mathrm{H}_{2}, 30.0 \% \mathrm{CO}$, $11.8 \% \mathrm{CO}_{2}$ and $27.6 \% \mathrm{H}_{2} \mathrm{O}$ under $\mathrm{SOFC}$ operating conditions. The syngas composition used here is same as that used in the experiments of Zhi et al.[26]. Phosphorous containing gas species considered in the present calculations include $\mathrm{PH}_{3}$ [49], $\left(\mathrm{P}_{2} \mathrm{O}_{3}\right)_{2}$ [49], $\left(\mathrm{P}_{2} \mathrm{O}_{5}\right)_{2}$ [49], $\mathrm{HPO}$ [48], $\mathrm{HPO}_{2}$ [51], $\mathrm{HPO}_{3}$ [51], CHP [49], CP [49], $\mathrm{P}_{2}$ [49], $\mathrm{P}_{4}$ [49], $\mathrm{PH}$ [49], $\mathrm{PH}_{2}$ [49], $\mathrm{PO}$ [49], $\mathrm{PO}_{2}$ [49] and condensed phases include $\mathrm{H}_{3} \mathrm{PO}_{4}$ (s) [49], $\mathrm{H}_{3} \mathrm{PO}_{4}(\mathrm{l})$ [49], $\left(\mathrm{H}_{3} \mathrm{PO}_{4}\right)_{2}\left(\mathrm{H}_{2} \mathrm{O}\right)$ (s) [48] and $\left(\mathrm{NH}_{4}\right) \mathrm{H}_{2} \mathrm{PO}_{4}$ (s) [48] .

The calculations showed that, without inclusion of the thermodynamic data for $\mathrm{HPO}_{2}$ and $\mathrm{HPO}_{3}, \mathrm{PH}_{3}$ mainly converts to $\left(\mathrm{P}_{2} \mathrm{O}_{3}\right)_{2}$ the most stable form of gas phase phosphorous containing species under equilibrium conditions. The equilibrium concentrations of $\mathrm{PH}_{3}$ and $\left(\mathrm{P}_{2} \mathrm{O}_{3}\right)_{2}$ as a function of the initial $\mathrm{PH}_{3}$ concentration $(1-20 \mathrm{ppm})$ and the system temperatures $\left(750-900^{\circ} \mathrm{C}\right)$ are shown in the phase diagram represented by Figure 3.1 (a). As can be seen from the figure, under the equilibrium condition, the major form of phosphorous in the gas phase is $\left(\mathrm{P}_{2} \mathrm{O}_{3}\right)_{2}$, which indicates that most of $\mathrm{PH}_{3}$ is oxidized due to the presence of high-concentration water vapor in the fuel gas. This is in agreement with the results reported in the literature [20]. It can also be seen from the figure that, the equilibrium concentration of $\left(\mathrm{P}_{2} \mathrm{O}_{3}\right)_{2}$ strongly depends on the initial concentration of $\mathrm{PH}_{3}$ but not on the temperature in the range of $750{ }^{\circ} \mathrm{C}-900{ }^{\circ} \mathrm{C}$.

Inclusion of the thermodynamic data for $\mathrm{HPO}_{2}$ and $\mathrm{HPO}_{3}$ to the calculations leads to the major phosphorus species to become $\mathrm{HPO}_{2}$ and $\left(\mathrm{P}_{2} \mathrm{O}_{3}\right)_{2}$ for a range of temperatures and 
$\mathrm{PH}_{3}$ concentrations relevant to syngas SOFCs. Figure 3.1 (b) illustrates the phase diagram showing equilibrium concentrations of $\mathrm{HPO}_{2}$ and $\left(\mathrm{P}_{2} \mathrm{O}_{3}\right)_{2}$ as a function of the initial $\mathrm{PH}_{3}$ concentration $(1-20 \mathrm{ppm})$ and the system temperatures $\left(750-900^{\circ} \mathrm{C}\right)$. As can be seen from the figure, $\mathrm{PH}_{3}$ was converted mostly to $\mathrm{HPO}_{2}(\mathrm{~g})$ at operating temperatures above $790^{\circ} \mathrm{C}$ regardless of the initial $\mathrm{PH}_{3}$ concentration. However, for temperatures below $790^{\circ} \mathrm{C}$, the major forms of the phosphorous impurity at equilibrium are $\mathrm{HPO}_{2}(\mathrm{~g})$ and $\left(\mathrm{P}_{2} \mathrm{O}_{3}\right)_{2}(\mathrm{~g})$. This indicates that, the critical temperature where the formation of $\left(\mathrm{P}_{2} \mathrm{O}_{3}\right)_{2}$ (g) becomes favorable is $790^{\circ} \mathrm{C}$.

\subsubsection{Multiphase Equilibrium Calculations}

Similar calculations have also been performed using simulated coal syngas with $\mathrm{PH}_{3}$ impurity by including possible condensed phase species anticipated to form between the phosphorous impurity and the $\mathrm{Ni}$ catalyst of the anode. Different from gas phase calculations, these calculations include time marching to allow for predicting the nickel conversion (to secondary phases) as a function of time during the operation of SOFC anode. The methodology used is to equilibrate the amount of coal syngas that would pass through the anode in one discrete time step with the amount of Ni present in the cell. After the equilibrium composition is obtained, the gas phase compositions are reset to original (inlet) values but the solid phase species compositions are kept the same as those obtained from the previous time step and the system is allowed to equilibrate again. This is akin to replacing the spent fuel with a fresh batch of fuel after each time step whereas $\mathrm{Ni}$ in the anode and its secondary phases never leave the system. The effect of current density was introduced by adding the amount of $\mathrm{H}_{2} \mathrm{O} / \mathrm{CO}_{2}$ produced and removing the amount of $\mathrm{H}_{2} / \mathrm{CO}$ reacted proportional to the current, within the discrete equilibrium time step. 


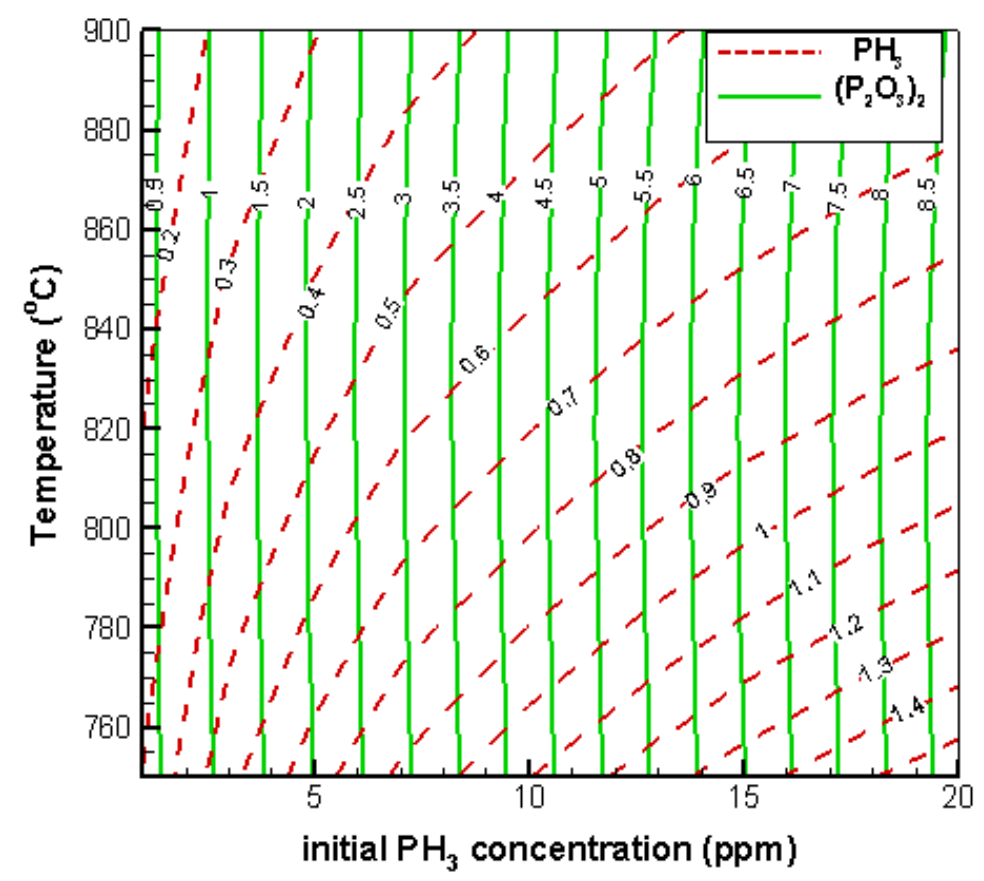

(a)

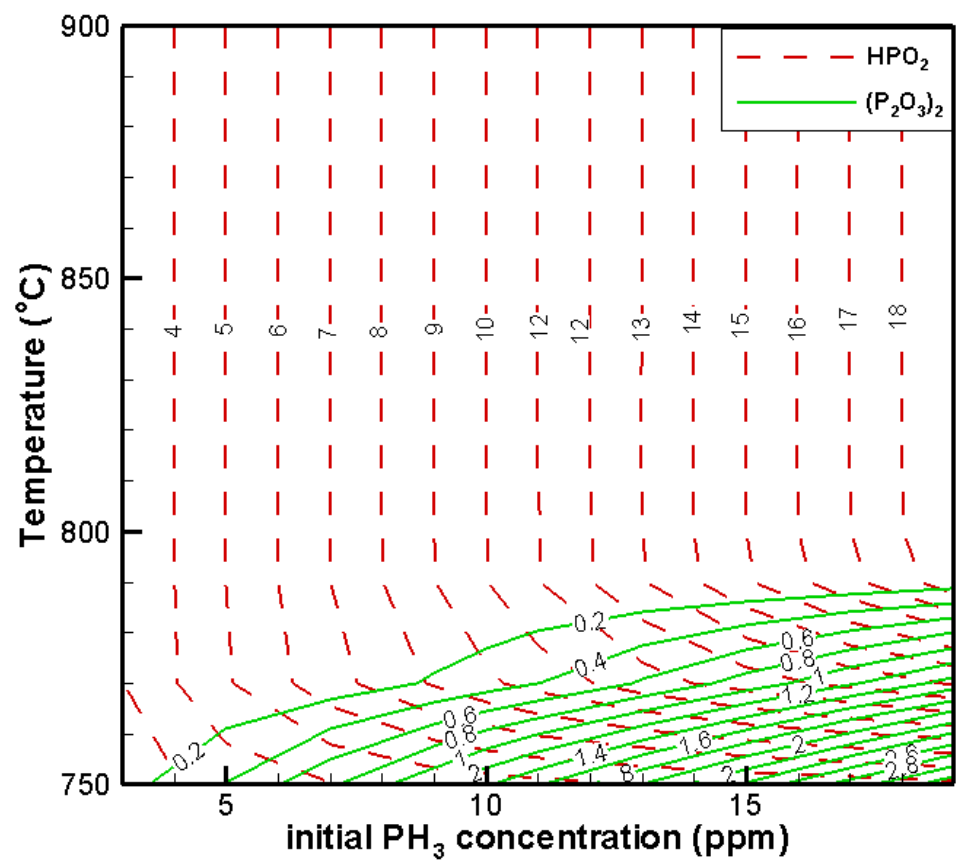

(b)

Figure 3. 1: Phase diagram showing the equilibrium concentration (ppm) of phosphorous containing species in coal syngas as a function of the initial $\mathrm{PH}_{3}$ concentration and the system temperatures for (a) without thermodynamic data of $\mathrm{HPO}_{2}$, (b) including thermodynamic data of $\mathrm{HPO}_{2}$ 
A numerical time step of $1 \mathrm{~s}$ was used assuming everything equilibrates within that time. In order to justify this assumption, the calculation was repeated for a specific case and it was seen that the results did not change when a time step of $10 \mathrm{~s}$ was used which means 1 $\mathrm{s}$ is enough for equilibrium (see Appendix A for the figure). Calculations are performed such that each fresh batch of fuel stream reacts with the remainder of the Ni from the previous time step, eventually depleting all the available $\mathrm{Ni}$.

Table 3.4 lists the equilibrium composition of phosphorous-containing species at $900^{\circ} \mathrm{C}$ and $1.0 \mathrm{~atm}$ after 48 hours of operation for initial $\mathrm{PH}_{3}$ concentrations of $10 \mathrm{ppm}$ and 15 ppm. As can be seen from the table, the major form of gas phase species is $\mathrm{HPO}_{2}$. In addition, independent of the initial concentration, only secondary phase formation observed is $\mathrm{Ni}_{5} \mathrm{P}_{2}$ (s). However, other researchers [23, 52, 53] report that other phosphides and even phosphates may form under SOFC operating conditions [26]. Marina et al. [23] note that equilibrium calculations involving phosphorus species are very sensitive to the species considered in the calculations and the source of the thermodynamic data used so it may not be possible to predict formation of other phosphides with the current thermodynamic data utilized.

Later the effect of system pressure on conversion of nickel to nickel phosphide at different initial $\mathrm{PH}_{3}$ concentrations was investigated and the results are given in Figure 3.2 at $750{ }^{\circ} \mathrm{C}$ and 0.5 amp. It can be seen from Figure 3.2 (a) and (b) that an increase in the initial concentration of $\mathrm{PH}_{3}$ results in an increase in the rate of formation of solid $\mathrm{Ni}_{5} \mathrm{P}_{2}$ phase thus accelerating the degradation. These results are consistent with the experimental data where it was shown that increase in contaminant concentrations leads to faster degradation [54]. It can also be seen that, although an increase in system pressure increases overall system efficiency for SOFCs, the equilibrium shifts toward formation of $\mathrm{Ni}_{5} \mathrm{P}_{2}$ (s) leading to faster degradation at higher operating pressure. 
Table 3. 4: Equilibrium composition of phosphorus-containing species at $900^{\circ} \mathrm{C}$ and 1.0 atm after 48 hours of operation

\begin{tabular}{|c|c|c|c|c|}
\hline & \multicolumn{2}{|c|}{10 ppm } & \multicolumn{2}{c|}{15 ppm } \\
\hline Species & Concentration (ppb) & Moles & Concentration (ppb) & Moles \\
\hline $\mathrm{PH}_{3}$ & $3.0 \mathrm{E}-07$ & $4.2 \mathrm{E}-17$ & $3.6 \mathrm{E}-07$ & $5.0 \mathrm{E}-17$ \\
\hline$\left(\mathrm{P}_{2} \mathrm{O}_{3}\right)_{2}$ & $2.0 \mathrm{E}+00$ & $2.8 \mathrm{E}-10$ & $4.1 \mathrm{E}+00$ & $5.7 \mathrm{E}-10$ \\
\hline$\left(\mathrm{P}_{2} \mathrm{O}_{5}\right)_{2}$ & $8.7 \mathrm{E}-26$ & $1.2 \mathrm{E}-35$ & $1.8 \mathrm{E}-25$ & $2.5 \mathrm{E}-35$ \\
\hline $\mathrm{CHP}$ & $2.2 \mathrm{E}-07$ & $3.1 \mathrm{E}-17$ & $2.6 \mathrm{E}-07$ & $3.7 \mathrm{E}-17$ \\
\hline $\mathrm{CP}$ & $1.6 \mathrm{E}-21$ & $2.2 \mathrm{E}-31$ & $1.9 \mathrm{E}-21$ & $2.7 \mathrm{E}-31$ \\
\hline $\mathrm{P}_{2}$ & $1.7 \mathrm{E}-16$ & $2.4 \mathrm{E}-26$ & $2.4 \mathrm{E}-16$ & $3.4 \mathrm{E}-26$ \\
\hline $\mathrm{P}_{4}$ & $1.2 \mathrm{E}-35$ & $1.7 \mathrm{E}-45$ & $2.4 \mathrm{E}-35$ & $3.4 \mathrm{E}-45$ \\
\hline $\mathrm{PH}^{2}$ & $3.9 \mathrm{E}-14$ & $5.5 \mathrm{E}-24$ & $4.7 \mathrm{E}-14$ & $6.6 \mathrm{E}-24$ \\
\hline $\mathrm{PH}_{2}$ & $1.9 \mathrm{E}-09$ & $2.6 \mathrm{E}-19$ & $2.2 \mathrm{E}-09$ & $3.2 \mathrm{E}-19$ \\
\hline $\mathrm{PO}^{2}$ & $7.2 \mathrm{E}-10$ & $1.0 \mathrm{E}-19$ & $8.6 \mathrm{E}-10$ & $1.2 \mathrm{E}-19$ \\
\hline $\mathrm{PO}_{2}$ & $2.8 \mathrm{E}-08$ & $3.9 \mathrm{E}-18$ & $3.3 \mathrm{E}-08$ & $4.7 \mathrm{E}-18$ \\
\hline $\mathrm{HPO}^{2}$ & $7.2 \mathrm{E}-06$ & $1.0 \mathrm{E}-15$ & $8.6 \mathrm{E}-06$ & $1.2 \mathrm{E}-15$ \\
\hline $\mathrm{HPO}_{2}$ & $2.7 \mathrm{E}+03$ & $3.8 \mathrm{E}-07$ & $3.2 \mathrm{E}+03$ & $4.6 \mathrm{E}-07$ \\
\hline $\mathrm{HPO}_{3}$ & $1.0 \mathrm{E}-04$ & $1.4 \mathrm{E}-14$ & $1.2 \mathrm{E}-04$ & $1.7 \mathrm{E}-14$ \\
\hline $\mathrm{Ni}_{5} \mathrm{P}_{2}$ & - & $5.4 \mathrm{E}-05$ & - & $7.5 \mathrm{E}-05$ \\
\hline
\end{tabular}

Figure 3.3 shows the effect of increasing temperature and current on formation of nickel phosphide phase. It can be seen from the figures that increasing temperature favors the conversion of $\mathrm{Ni}_{\text {to }} \mathrm{Ni}_{5} \mathrm{P}_{2}$ (s). Analysis of Figure 3.33 (a) and (b) also reveals that an increase in total current decreased the amount of $\mathrm{Ni}_{5} \mathrm{P}_{2}$ (s) formed as opposed to the experiments [26]. The reason for this discrepancy can be attributed to equilibrium calculations not taking into account of chemical kinetics.

Trembly et al. [29] also performed similar calculations considering interactions of As, P, and $\mathrm{Sb}$ impurities with Ni catalyst of the SOFC anode. Different from the current study, 
the authors analyzed thin sections at the inlet and outlet edges of the anode rather than considering whole anode. In addition, the amount of nickel equilibrating with the coal syngas with impurities was taken as constant for each calculation allowed to equilibrate for $1,100,500,1000,3000$ and 10,000 h. This approach overpredicts the amount of secondary phases formed with the $\mathrm{Ni}$ catalyst since it neglects the amount of $\mathrm{Ni}$ converted in the previous calculation. In other words, in each calculation the impurity species equilibrate with the same amount of $\mathrm{Ni}$.

\subsection{Summary and Conclusions}

Gas phase equilibrium calculations were performed to determine the partitioning behavior of coal syngas impurities between the gas and condensed phases under warm gas cleanup conditions and to identify the effect of SOFC operating conditions on the equilibrium status of phosphorous upon introduction of $\mathrm{PH}_{3}$ to the simulated coal syngas. Following conclusions can be drawn form gas phase equilibrium calculations:

- Under warms gas cleanup conditions $\left(200-500^{\circ} \mathrm{C}\right.$ and $\left.1 \mathrm{~atm}\right)$, trace species like $\mathrm{Be}, \mathrm{Cr}, \mathrm{K}, \mathrm{Na}$, and $\mathrm{V}$ in coal syngas form condensed phases and can be removed efficiently before reaching SOFC anode. However, $\mathrm{Sb}, \mathrm{As}, \mathrm{Cd}, \mathrm{Pb}, \mathrm{Hg}, \mathrm{P}, \mathrm{Zn}$ and Se form vapor phase species can react with the anode material

- Under the equilibrium conditions, the major form of phosphorous in the gas phase was $\mathrm{HPO}_{2}(\mathrm{~g})$ at operating temperatures above $790^{\circ} \mathrm{C}$. For temperatures below $790^{\circ} \mathrm{C}$, the major forms of the phosphorous impurity at equilibrium are $\mathrm{HPO}_{2}(\mathrm{~g})$ and $\left(\mathrm{P}_{2} \mathrm{O}_{3}\right)_{2}(\mathrm{~g})$ indicating the critical temperature where formation of $\left(\mathrm{P}_{2} \mathrm{O}_{3}\right)_{2}(\mathrm{~g})$ becomes favorable is $790^{\circ} \mathrm{C}$.

- For temperatures above $790^{\circ} \mathrm{C}$, the equilibrium concentration of $\mathrm{HPO}_{2}(\mathrm{~g})$ depends heavily on the initial concentration of $\mathrm{PH}_{3}$ but much less dependent on the temperature. 


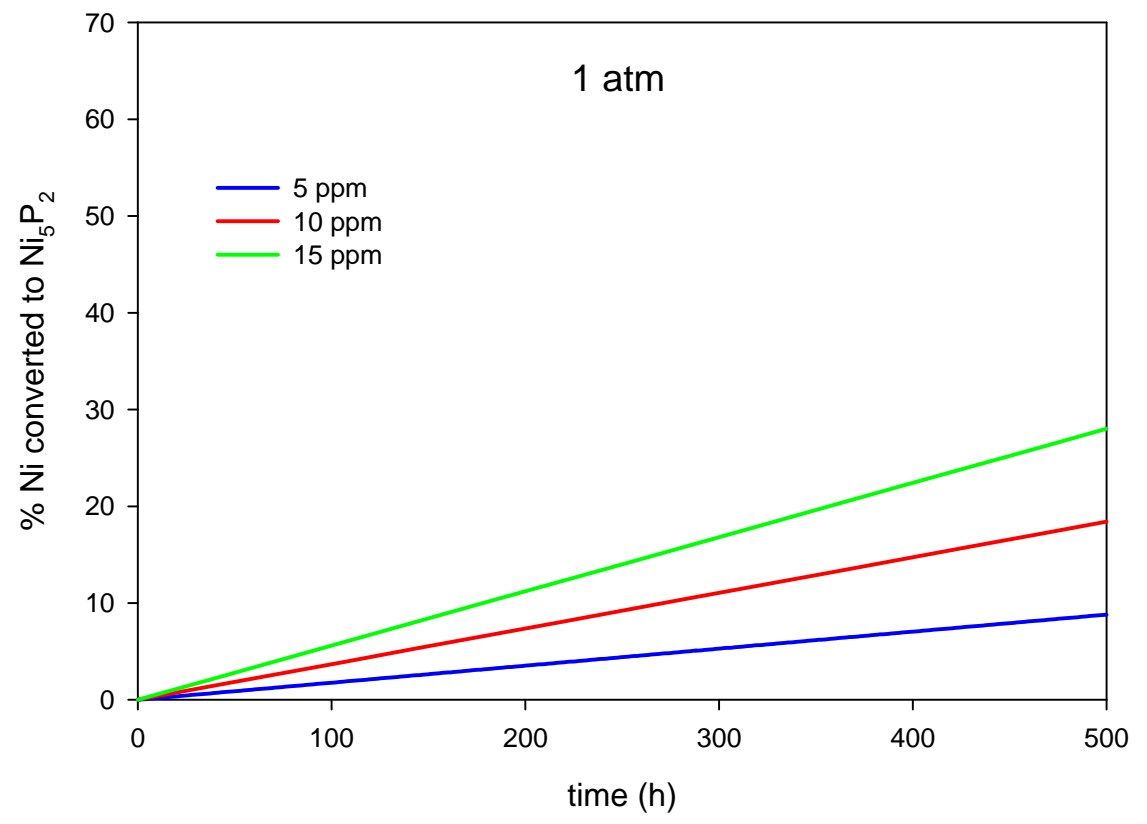

(a)

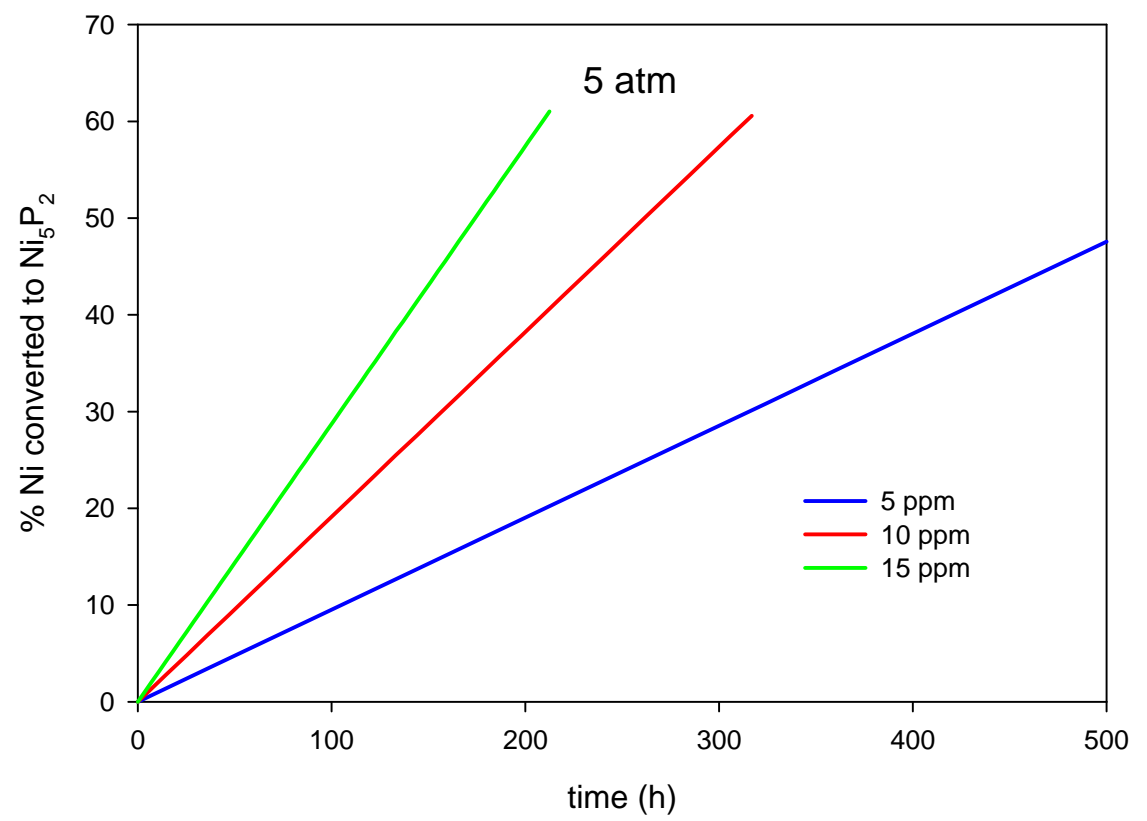

(b)

Figure 3. 2: Effect of pressure on nickel to nickel phosphide conversion at different initial $\mathrm{PH}_{3}$ concentrations at $750{ }^{\circ} \mathrm{C}$ and $0.5 \mathrm{amp}$ 


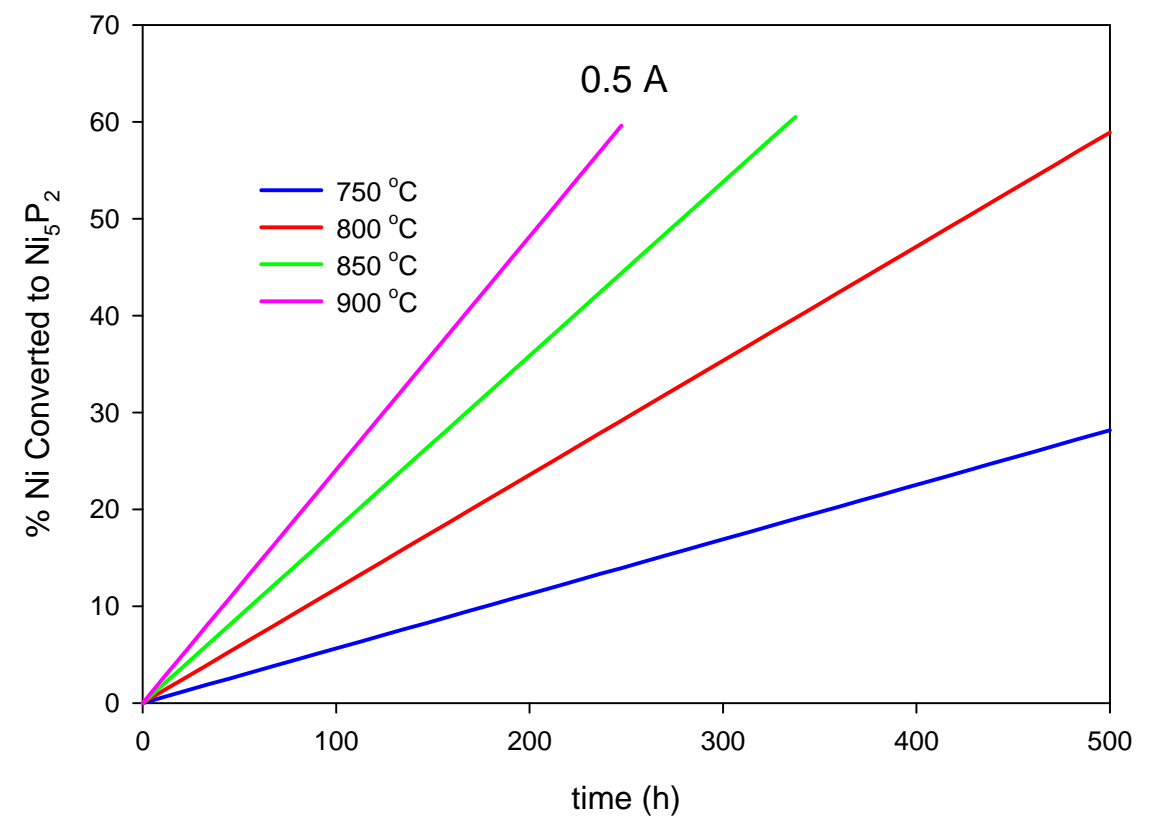

(a)

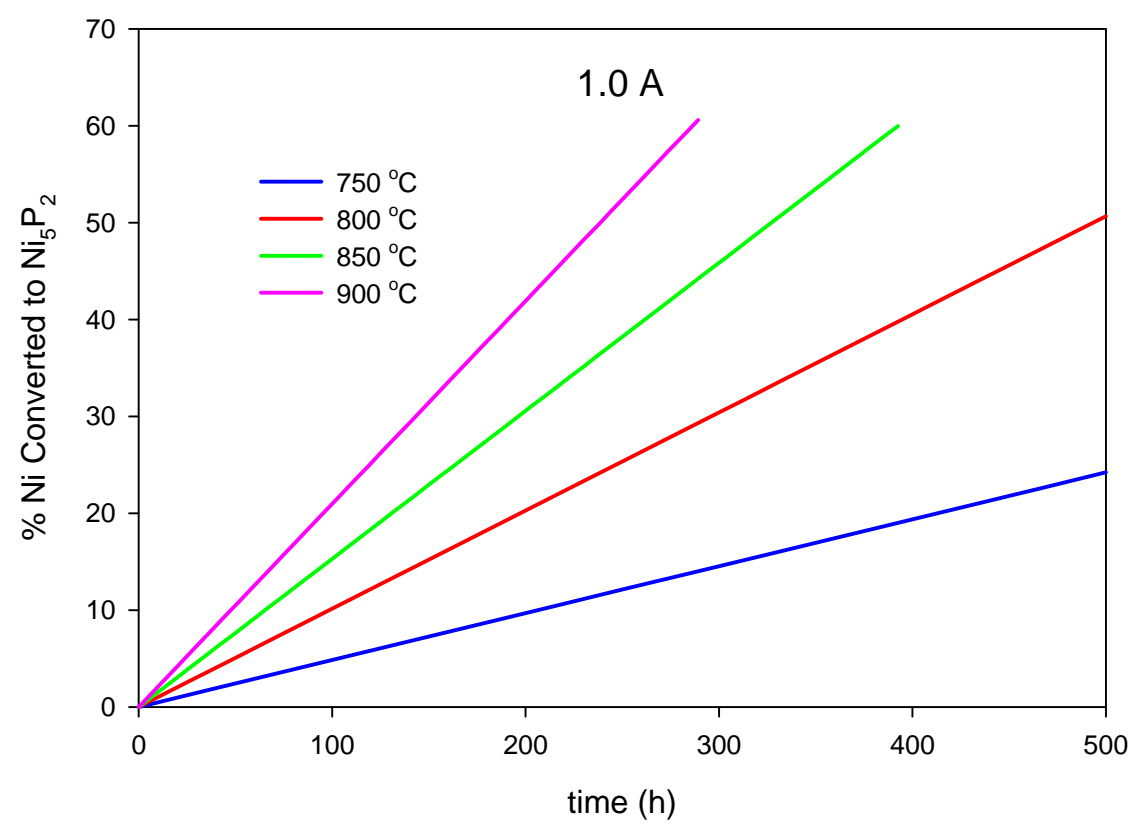

(b)

Figure 3. 3: Effect of current at different temperatures to nickel to nickel phosphide conversion for 15 ppm initial concentration of $\mathrm{PH}_{3}$ at 1 atm 
Similar calculations have also been performed using simulated coal syngas with $\mathrm{PH}_{3}$ impurity to predict the activity of phosphorous in coal syngas by formation of specific Ni-P solid phases and it was concluded that:

- Only secondary $\mathrm{Ni}_{5} \mathrm{P}_{2}$ (s) phase formation was observed for all temperatures, pressures, initial impurity concentrations and currents analyzed during this study as opposed to some where the majority of $\mathrm{Ni}$ was found to convert to $\mathrm{Ni}_{3}\left(\mathrm{PO}_{4}\right)_{2}$ (s) or other forms of phosphides such as $\mathrm{Ni}_{2} \mathrm{P}$ and $\mathrm{Ni}_{3} \mathrm{P}$.

- Increase in initial $\mathrm{PH}_{3}$ concentration and temperature increased the rate of formation of $\mathrm{Ni}_{5} \mathrm{P}_{2}$ (s) thus accelerating the degradation process

- Increase in system pressure increases overall system efficiency of SOFCs however at higher pressures the equilibrium shifts toward formation of $\mathrm{Ni}_{5} \mathrm{P}_{2}(\mathrm{~s})$.

- Increase in total current decreased the amount of $\mathrm{Ni}_{5} \mathrm{P}_{2}$ (s) formed as opposed to the experiments possibly due to neglecting chemical kinetics. 


\section{CHAPTER 4- MULTI-COMPONENT DIFFUSION INSIDE POROUS ANODE}

This chapter is organized as follows. Section 4.1 presents a brief overview of the models for multi-component diffusion in porous media that are used in the literature. Section 4.2 and 4.3 describe the model equations used for the current study and the numerical solution method used for solving these model equations, respectively. Section 4.4 presents the implicit verification of the model by comparing its predictions against an independent numerical solution for the same problem. Section 4.5 introduces a correction for the multi-component effective diffusivity and the results form application of this correction to syngas transport through the porous anode. Section 4.6 provides the summary and conclusions for this study.

\subsection{Overview}

The performance of a SOFC at high operating current densities is reduced mainly due to the mass transport losses, that is, the demand for reactants exceeds their capacity to diffuse through the porous anode to the reaction site at the anode-electrolyte interface. The multi-component mass transport in SOFC anodes is also coupled with the bulk chemical reactions and the resulting diffusion and reaction time scales of different species dictate the limiting behavior. Accurate modeling of this phenomenon is imperative for development of better fuel cell designs. 
The equations governing the multi-component mass transfer include Stefan-Maxwell relations for calculation of species fluxes. These relations are coupled, nonlinear system of partial differential equations and are cumbersome to solve, especially when a large number of species are involved as in the case of coal syngas. Alternatively, simple Fick's Law type relations with an effective multi-component diffusivity are generally used to model the diffusion fluxes [55-58]. Advantages of using Fick's Law type of relations Stefan-Maxwell relations include simplicity of implementation since they can be directly substituted to the species conservation equation and requirement of less computation time. The latter is especially important when the species conservation equation is solved in conjunction with other governing equations for momentum and heat transfer, as is the case of 3-D modeling of Solid Oxide Fuel Cells. However, the validity of such simplified models is not well established.

In this study, these two approaches are compared by simulating mass transfer inside an SOFC anode operating on coal syngas consisting of $\mathrm{CH}_{4}, \mathrm{H}_{2}, \mathrm{CO}, \mathrm{H}_{2} \mathrm{O}, \mathrm{CO}_{2}$ and $\mathrm{N}_{2}$. A two-dimensional computer code was developed for the solution of models based on Stefan-Maxwell and Fick's Law flux relations to predict the species concentration distribution inside the porous anode. Methane steam reforming and water gas shift reactions are taken into account in addition to the electrochemical reactions at the anode/electrolyte interface and chemical kinetics modeling was employed for the bulk reactions. The ratio between the current produced by $\mathrm{CO}$ and $\mathrm{H}_{2}$ oxidation is assumed to be constant.

\subsection{Model Equations}

Diffusion transport inside the porous medium has two components: bulk molecular diffusion where molecular to molecular interaction dominates the transport and Knudsen diffusion where molecular to solid wall interaction dominates the transport. 
Several different approaches have been developed to evaluate multi-component porous media transport $[57,59,60]$. In the present study, Stefan-Maxwell Model (SMM) and Fick's Model (FM) both of which include the effect of Knudsen diffusion in addition to the bulk molecular diffusion were used.

The flux expression in Stefan-Maxwell model is given by [61]:

$$
\frac{\boldsymbol{N}_{i}}{D_{i}^{k^{*}}}+\sum_{\substack{j=1 \\ j \neq i}}^{n} \frac{y_{j} \boldsymbol{N}_{i}-y_{i} \boldsymbol{N}_{j}}{D_{i j}^{*}}=-\frac{P}{R T} \nabla y_{i}
$$

where $N_{i}$ and $y_{i}$ are the molar fluxes and mole fractions of species, $D_{i j}^{*}$ and $D_{i}^{k^{*}}$ are the effective binary and Knudsen diffusivities. The first term on the left hand side accounts for the Knudsen diffusion and the second one signifies the multi-component bulk molecular diffusion.

The effective binary diffusivity is usually defined as:

$$
D_{i j}^{*}=\frac{\varepsilon}{\tau} D_{i j}
$$

where $\varepsilon$ and $\tau$ are the bulk porosity and tortuosity, respectively. $D_{i j}$ is the binary diffusivity and can be calculated using Chapman- Enskog relations [61]:

$$
D_{i j}=0.001858 \frac{\left[T^{3}\left(M_{i}+M_{j}\right) / M_{i} M_{j}\right]^{1 / 2}}{P \sigma_{i j}^{2} \Omega_{D}}
$$

where $T$ and $P$ are the temperature and the pressure of the system, respectively. $M_{i}$ represents the molecular weight of species $i . \sigma_{i j}$ is given by 
$\sigma_{i j}=\frac{\sigma_{i}+\sigma_{j}}{2}$

$\sigma_{i}$ is the collision diameter of species $i$. The dimensionless parameter $\Omega_{D}$ is the collision integral calculated as

$\Omega_{D}=\frac{A}{T_{N}^{B}}+\frac{C}{\exp \left(D T_{N}\right)}+\frac{E}{\exp \left(F T_{N}\right)}+\frac{G}{\exp \left(H T_{N}\right)}$

where the coefficients A, B, C, D, E, F, G, H are 1.06036, 0.1561, 0.193, 0.47635, $1.03587,1.52996,1.76474,3.89411$, respectively [62]. The dimensionless temperature $T_{N}$ is defined as:

$T_{N}=\frac{k T}{\varepsilon_{i j}}$

where $k$ is the Boltzmann constant. The term $\varepsilon_{i j}$ is calculated as

$\varepsilon_{i j}=\left(\varepsilon_{i} \varepsilon_{j}\right)^{1 / 2}$

where $\varepsilon_{i}$ is the characteristic Lenard-Jones energy of species $i$.

Likewise Knudsen diffusivity is defined as:

$D_{i}^{k^{*}}=\frac{\varepsilon}{\tau}\langle r\rangle \frac{2}{3} \sqrt{\frac{8 R T}{\pi M_{i}}}$

where $\langle r\rangle$ is the mean pore radii and $R$ is the universal gas constant .

Fick's Model (FM), a simpler method used to describe the transport of species in the gas phase, is defined as: 


$$
N_{i}=-D_{i}^{\text {eff }} \frac{P}{R T} \nabla y_{i}
$$

where $D_{i}^{\text {eff }}$ is the effective diffusivity. Simulations with Fick's Model were conducted by using the effective multi-component diffusivity proposed by Yakabe et al. [57]:

$$
D_{i}^{e f f}=\frac{\varepsilon}{\tau}\left[\frac{1-\alpha_{i, m} y_{i}}{D_{i, m}}+\frac{1}{D_{i}^{k}}\right]^{-1}
$$

$\alpha_{i, m}$ is a dimensionless parameter given by:

$$
\alpha_{i, m}=1-\left(M_{i} / M_{\text {avg }}\right)^{1 / 2}
$$

where $M_{\text {avg }}$ is the average molecular weight and $M_{i}$ is the molecular weight of the species $i$. Multi-component molecular diffusivity of species $i$ in the mixture $D_{i, m}$ is given by

$$
D_{i, m}=\frac{1-y_{i}}{\sum_{j \neq i} \frac{y_{j}}{D_{i j}}}
$$

The calculated molar fluxes either from SMM (Eq.(4.1)) or from FM (Eq.(4.9)) are then used to determine the rate of change of species concentrations through the following conservation equation:

$\varepsilon \frac{P}{R T} \frac{\partial y_{i}}{\partial t}=-\nabla N_{i}+R_{i}$

where $R_{i}$ is the molar rate of production of species $i$ due to bulk chemical reactions.

In the present study, the principle bulk chemical reactions of concern are methane steam reforming and water gas shift reactions, described respectively as: 


$$
\begin{aligned}
& \mathrm{CH}_{4}+\mathrm{H}_{2} \mathrm{O} \underset{k_{r}^{-}}{\stackrel{k_{r}^{+}}{\rightleftharpoons}} 3 \mathrm{H}_{2}+\mathrm{CO} \\
& \mathrm{CO}+\mathrm{H}_{2} \mathrm{O} \underset{k_{s}^{-}}{\stackrel{k^{+}}{\rightleftharpoons}} \mathrm{CO}_{2}+\mathrm{H}_{2}
\end{aligned}
$$

where $k_{r}^{+}$and $k_{r}^{-}$are the forward and backward reaction rate constants for reforming reaction and $k_{s}^{+}$and $k_{s}^{-}$are the reaction rate constants for shift reaction Experimentally determined values for these rate constants and their Arrhenius form can be found in [63, 64]. The net reaction rates are given for reforming and shift reactions, respectively as:

$$
\begin{aligned}
& R_{r}=k_{r}^{+} p_{\mathrm{CH}_{4}} p_{\mathrm{H}_{2} \mathrm{O}}-k_{r}^{-} p_{\mathrm{CO}}\left(p_{\mathrm{H}_{2}}\right)^{3} \\
& R_{s}=k_{s}^{+} p_{\mathrm{CO}} p_{\mathrm{H}_{2} \mathrm{O}}-k_{s}^{-} p_{\mathrm{CO}_{2}} p_{\mathrm{H}_{2}}
\end{aligned}
$$

where $P_{i}$ is the partial pressure of species $i$.

\subsection{Numerical Solution Method}

A finite volume method is used to discretize the governing equation given in Eq. (4.13). Crank-Nicholson method is used for time discretization but source terms are treated fully explicit. The specified boundary conditions are the species concentration at the anode fuel channel interface and molar fluxes at anode electrolyte interface proportional to the prescribed cell current. It is assumed that there is zero flux of species at the two side walls. The ratio between the current produced by $\mathrm{CO}$ and $\mathrm{H}_{2}$ electrochemical oxidation is assumed to be constant and taken as 4 for the current study [65]. 


\subsection{Model Validation}

As explained in the section 4.2, Stefan Maxwell Model (SMM) and Fick's Model (FM) are the two of the models which are used to calculate the fluxes of each species in a multi-component system. Here these two approaches were compared by simulating mass transfer inside an SOFC anode operating on coal syngas consisting of $\mathrm{CH}_{4}, \mathrm{H}_{2}, \mathrm{CO}, \mathrm{H}_{2} \mathrm{O}$, $\mathrm{CO}_{2}$ and $\mathrm{N}_{2}$. A two-dimensional computer code was developed for the solution of models based on Stefan-Maxwell and Fick's Law flux relations to predict the species concentration distribution inside the porous anode. A schematic representation of the SOFC anode used for this study is shown in Figure 4.1.

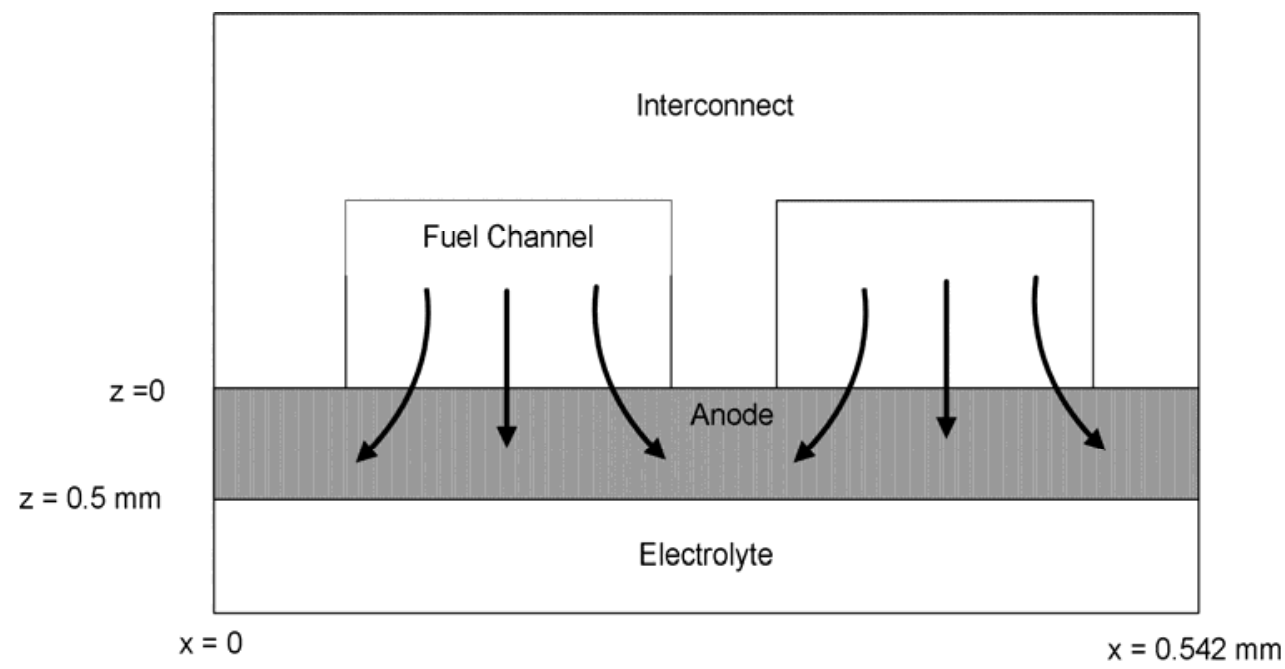

Figure 4. 1: Schematic representation of the SOFC anode

The predictive ability of the developed code is verified by comparing the results of molar formation rates to those of [35] that also used SMM to predict the species molar fluxes for an identical case. The syngas composition used is $2.9 \% \mathrm{CO}, 2.63 \% \mathrm{H}_{2}, 0.44 \% \mathrm{CO}_{2}$, $4.93 \% \mathrm{H}_{2} \mathrm{O}$ and $1.71 \% \mathrm{CH}_{4}$. Table 4.1 summarizes the parameters used for comparison.

Table 4. 1: Parameters used for comparison 


\begin{tabular}{cc}
\hline Parameter & Value \\
\hline Anode Thickness $(\mathrm{mm})$ & 2.0 \\
\hline Temperature $\left({ }^{\circ} \mathrm{C}\right)$ & 850 \\
\hline Current Density $\left(\mathrm{A} / \mathrm{cm}^{2}\right)$ & 0.3 \\
\hline Mean pore diameter, $\langle r\rangle(\mu \mathrm{m})$ & 1.07 \\
\hline Operating temperature $(\mathrm{K})$ & 1123 \\
\hline Tortuosity & 3.6 \\
\hline Porosity & 0.56 \\
\hline
\end{tabular}

Figure 4.2 shows a good agreement between two independent calculations which indicates the model was successfully implemented.

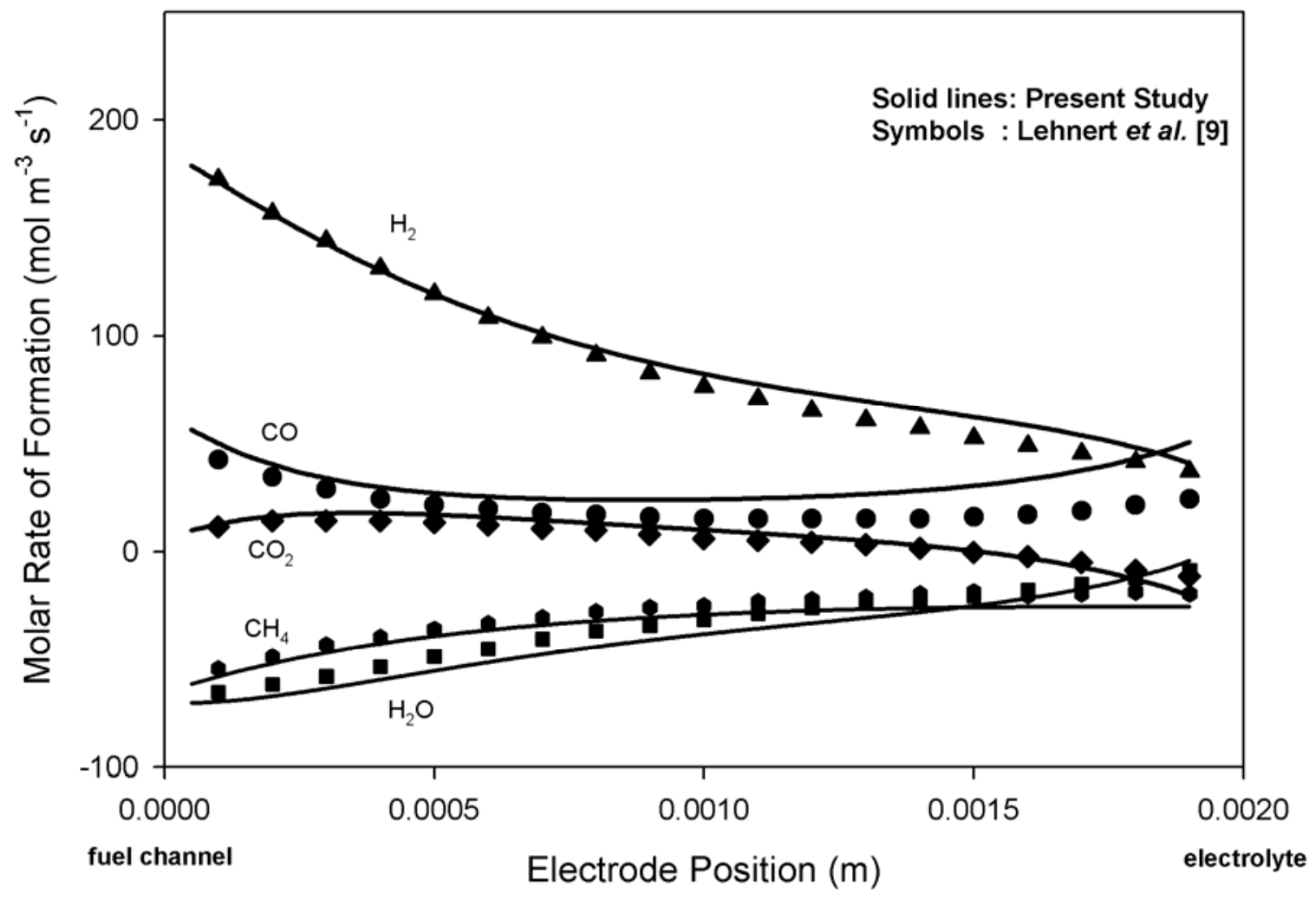

Figure 4. 2: Comparison between the molar rate of formation results of the present study and those of [35] 


\subsection{Correction of Effective Diffusivity}

The 2-D code validated above is then used to compare the results obtained using Fick's model for diffusion flux with those obtained using Stefan-Maxwell model. Figure 4.3 shows the maximum percentage difference (deviation from SMM predictions of concentration) of Fick's Model vs. current density.

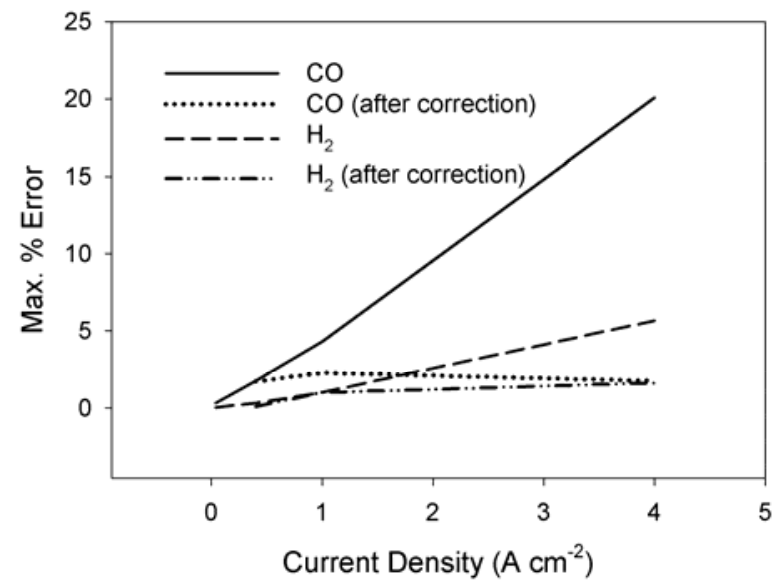

(a)

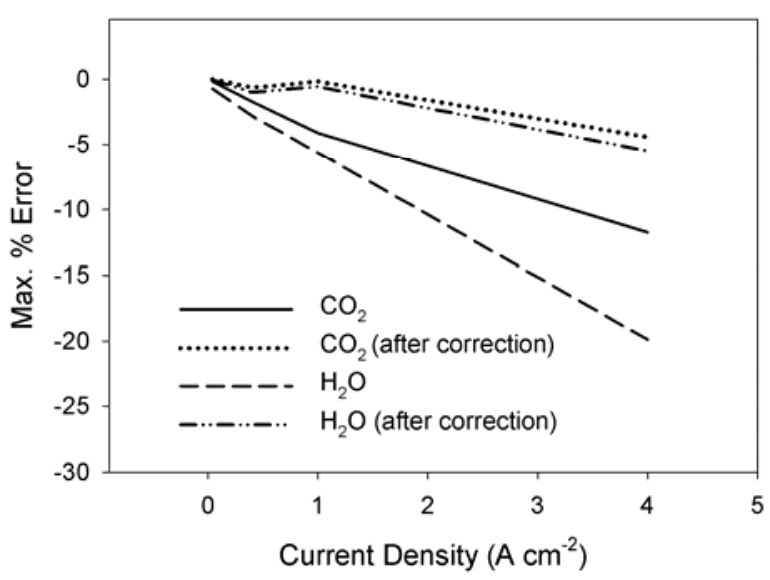

(b)

Figure 4. 3: Maximum percentage difference of Fick's model versus current density for (a) reactants, (b) products

As can be seen from the figure, at low current densities the models agree well but as current increases the differences increase to up to $20 \%$ at a current density of $4 \mathrm{~A} / \mathrm{cm}^{2}$. The difference in the Fick's Law model is positive for the fuel species (reactants) and negative for the products. Based on these findings an empirical correction is proposed for the effective diffusivity used in Fick's law model as:

$$
D_{i}^{\text {eff * }}=D_{i}^{e f f}\left(1 \pm c \frac{i}{i_{\text {ref }}}\right)^{n}
$$

where $i$ is the total current density and $i_{\text {ref }}$ is the reference current density taken as 1 $\mathrm{A} / \mathrm{m}^{2}$. The sign in the equation is taken as $(+)$ for reactants $\left(\mathrm{H}_{2}\right.$ and $\left.\mathrm{CO}\right)$ and $(-)$ for 
products $\left(\mathrm{H}_{2} \mathrm{O}\right.$ and $\left.\mathrm{CO}_{2}\right)$. Model parameters $\mathrm{c}$ and $\mathrm{n}$ are found as $4.88 \times 10^{-4}$ and 2 , respectively, by calibrating it with the SMM using the two-dimensional code presented here.

The corrected diffusivities were used to predict the species concentration distribution inside an SOFC anode running on coal syngas. Anode was treated as a two-dimensional medium. Tables 4.2 and 4.3 show the syngas composition and the anode electrode properties used for simulations.

Table 4. 2: Coal syngas composition

\begin{tabular}{cc}
\hline Species & Mole Fractions \\
\hline $\mathrm{CO}$ & 0.291 \\
\hline $\mathrm{H}_{2}$ & 0.285 \\
\hline $\mathrm{CO}_{2}$ & 0.118 \\
\hline $\mathrm{H}_{2} \mathrm{O}$ & 0.276 \\
\hline $\mathrm{CH}_{4}$ & 0.021 \\
\hline $\mathrm{N}_{2}$ & 0.009 \\
\hline
\end{tabular}

Table 4. 3: Anode Properties

\begin{tabular}{cc}
\hline Parameter & Value \\
\hline Thickness $(\mathrm{mm})$ & 0.5 \\
\hline Width $(\mathrm{mm})$ & 0.542 \\
\hline Tortuosity & 3.6 \\
\hline Porosity & 0.56 \\
\hline Mean pore diameter, $\langle r\rangle(\mu \mathrm{m})$ & 1.07 \\
\hline Operating temperature $(\mathrm{K})$ & 1123 \\
\hline
\end{tabular}


Mole fraction distributions inside the porous anode directly below the fuel channel is given in Figures 4.5 and 4.6 for operating current densities of $1 \mathrm{~A} / \mathrm{cm}^{2}$ and $4 \mathrm{~A} / \mathrm{cm}^{2}$, respectively. As can be seen from the figures the corrected diffusivity coefficient gave better agreement with the Stefan-Maxwell model and even at higher current densities the error is less than $5 \%$ (see Figure 4.4). Since this correction is based on numerical experiments it is expected to have some errors and $5 \%$ error is acceptable for such a heuristic model.

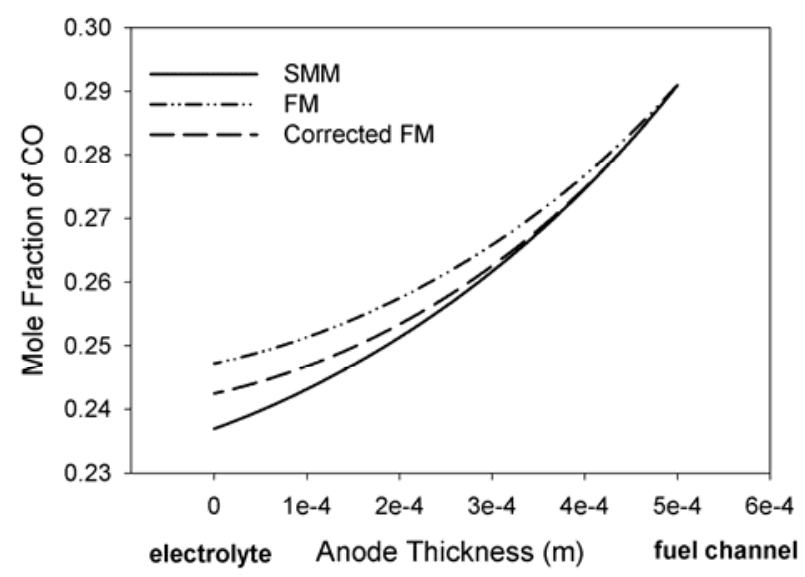

(a)

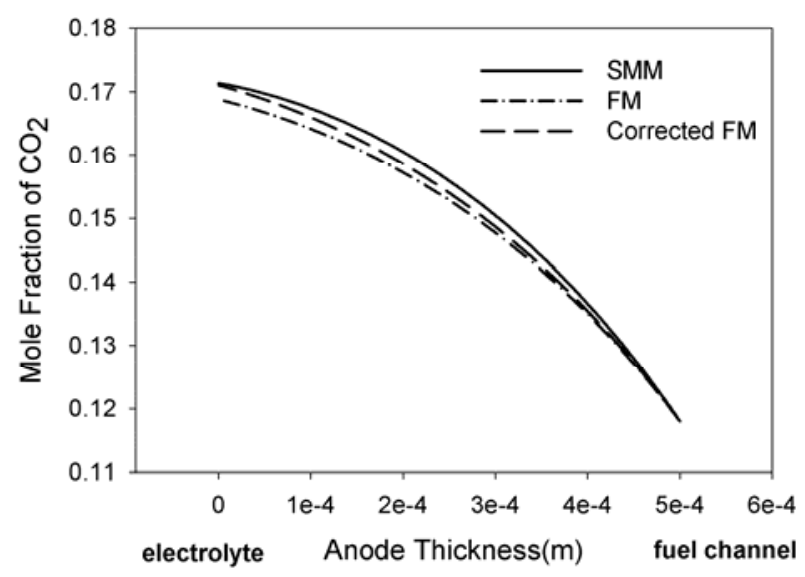

(c)

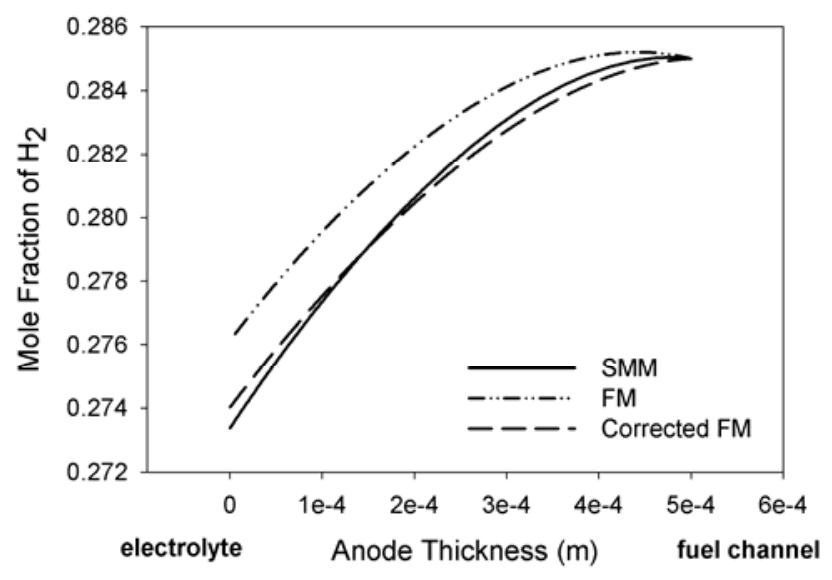

(b)

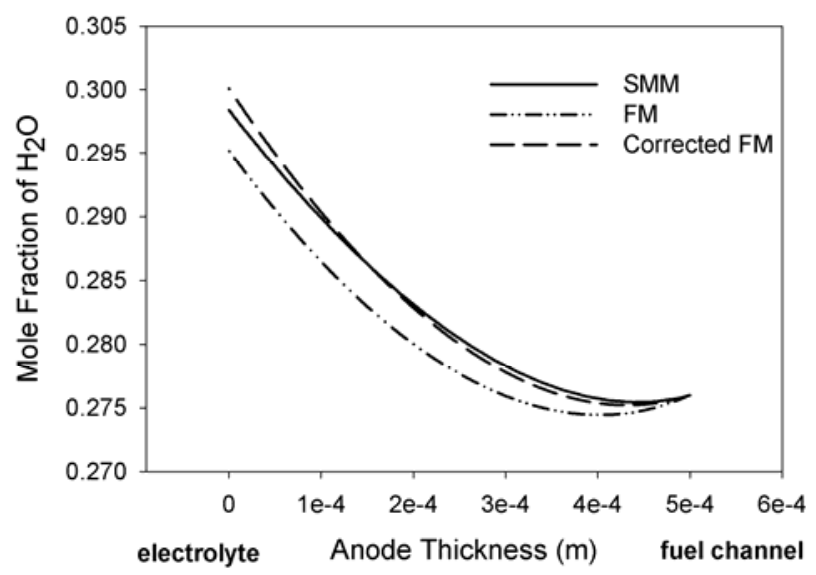

(d)

Figure 4. 4: Concentration profiles along the anode thickness predicted by FM and SMM for (a)CO, (b) $\mathrm{H}_{2}$, (c) $\mathrm{CO}_{2}$ and (d) $\mathrm{H}_{2} \mathrm{O}$ at $1 \mathrm{~A} / \mathrm{cm}^{2}$ 


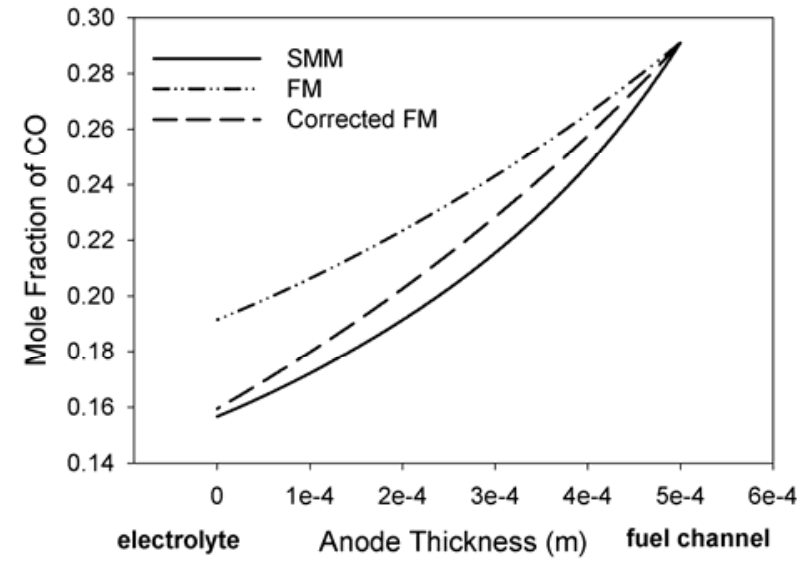

(a)

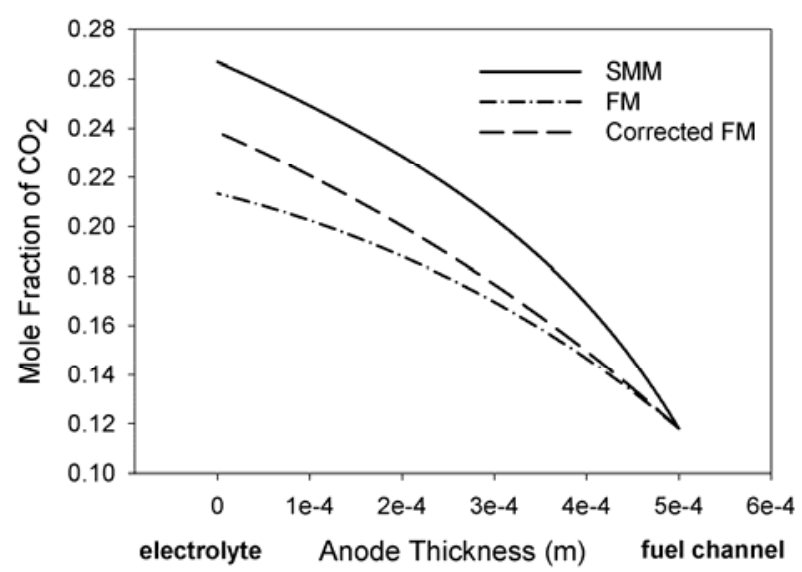

(c)

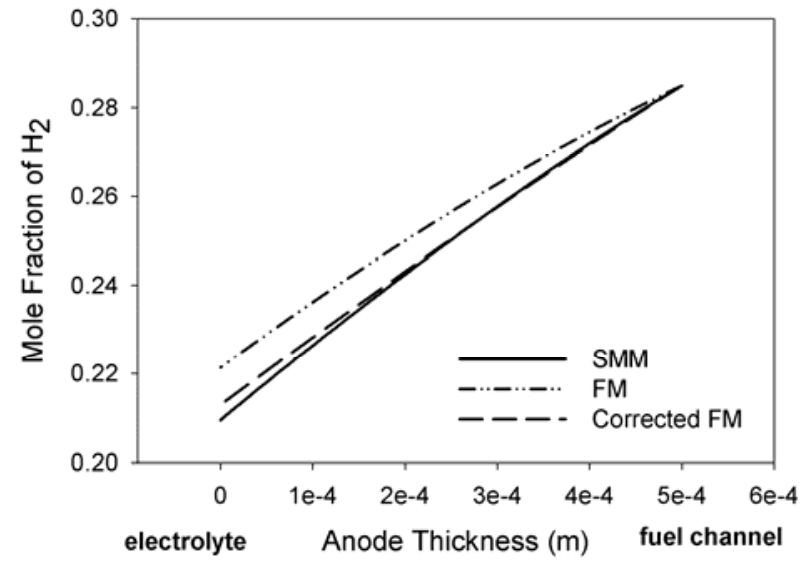

(b)

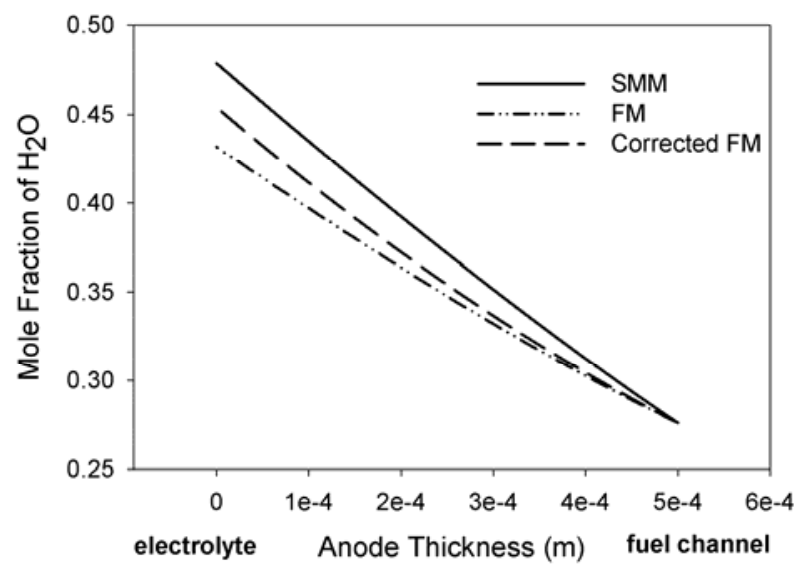

(d)

Figure 4. 5: Concentration profiles along the anode thickness predicted by FM and SMM for (a)CO (b) $\mathrm{H}_{2}$ (c) $\mathrm{CO}_{2}$ and (d) $\mathrm{H}_{2} \mathrm{O}$ at $4 \mathrm{~A} / \mathrm{cm}^{2}$

The estimated reaction and diffusion time scales for the conditions used in the above simulation normalized with the flow through time $\left(\tau_{\text {conv }}=\mathrm{L} / \mathrm{u}=0.267 \mathrm{~s}\right.$ with $\mathrm{L}$ being fuel channel length and $u$ being average velocity inside the channel) of the fuel in the gas channel are given in Tables 4.4 and 4.5 respectively. It can be seen from Table 4.4 that there is ample time for the component species to diffuse through the anode as they flow through the gas channel. Normalized reaction time scales (Table 4.5) indicate that, with the given inlet concentrations, steam methane reformation mostly proceeds in the forward 
direction whereas as water gas shift reactions may proceed in both directions. Moreover diffusion time scales are much smaller compared to reaction time scales indicating that this electrode is not limited by diffusion.

Table 4. 4: Normalized diffusion time scales

\begin{tabular}{ll}
\hline Species & $\tau_{\text {diff }} / \tau_{\text {conv }}$ \\
\hline $\mathrm{CO}$ & 0.030486 \\
\hline $\mathrm{H}_{2}$ & 0.008841 \\
\hline $\mathrm{CO}_{2}$ & 0.038900 \\
\hline $\mathrm{H}_{2} \mathrm{O}$ & 0.025321 \\
\hline $\mathrm{CH}_{4}$ & 0.028375 \\
\hline
\end{tabular}

Table 4. 5: Normalized reaction time scales

\begin{tabular}{lll}
\hline & $\tau_{\text {chem }} / \tau_{\text {conv }}$ \\
\hline & Forward & Backward \\
\hline $\begin{array}{l}\text { Steam Methane } \\
\text { Reforming }\end{array}$ & 0.169621 & 1570.154 \\
Water Gas Shift & 0.069015 & 0.048962 \\
\hline
\end{tabular}




\subsection{Application: Button Cell}

In order to independently verify the proposed corrections to the effective diffusivities used in Fick's law type models applied to the multi-component mass transfer problems in fuel cells; this approach is employed in a three dimensional simulation of a real button cell. The model used for these simulations is described elsewhere $[66,67]$ in the literature and will not be covered here. The salient features of the model are that it allows for several species and bulk-reactions on the anode side and it handles the simultaneous electrochemical oxidation on $\mathrm{CO}$ and $\mathrm{H}_{2}$ without assuming a constant ratio between the current produced by each; rather this ratio is an outcome of the model (see ref. [68] ). Also, the diffusion fluxes are calculated using Fick's law type relations and the effective diffusivities are calculated using the model in Eq. (4.10). The button cell simulated here is modeled after the experiments being performed at WVU [69]. The active area of the button cell is approximately $2 \mathrm{~cm}^{2}$. The anode, electrolyte and cathode thicknesses are $780 \mu \mathrm{m}, 20 \mu \mathrm{m}$ and $200 \mu \mathrm{m}$ respectively. The fuel stream fed to the anode has the composition shown in Table 4.6. The cathode side is supplied with air $\left(21 \% \mathrm{O}_{2}\right.$ and $79 \%$ $\mathrm{N}_{2}$ ). Both air and fuel streams are supplied at a temperature of $800{ }^{\circ} \mathrm{C}$. The flow field around the button cell is not included in the computation domain. However, its effect on the cell is taken into account using appropriate boundary conditions and transport properties. Given the low utilization of fuel and air in the button cell experiments, it was found that the current density distribution inside the cell was uniform at all currents.

Table 4. 6: Fuel composition supplied to the anode

\begin{tabular}{ccccc}
\hline Species & $\mathrm{H}_{2}$ & $\mathrm{CO}$ & $\mathrm{CO}_{2}$ & $\mathrm{H}_{2} \mathrm{O}$ \\
Mol fraction & 0.303 & 0.229 & 0.209 & 0.259 \\
\hline
\end{tabular}

Figure 4.6 shows the experimentally measured and numerically computed VI curves for the button cell. Computations are performed both with and without the proposed correction to the effective multi-component diffusion coefficients. 


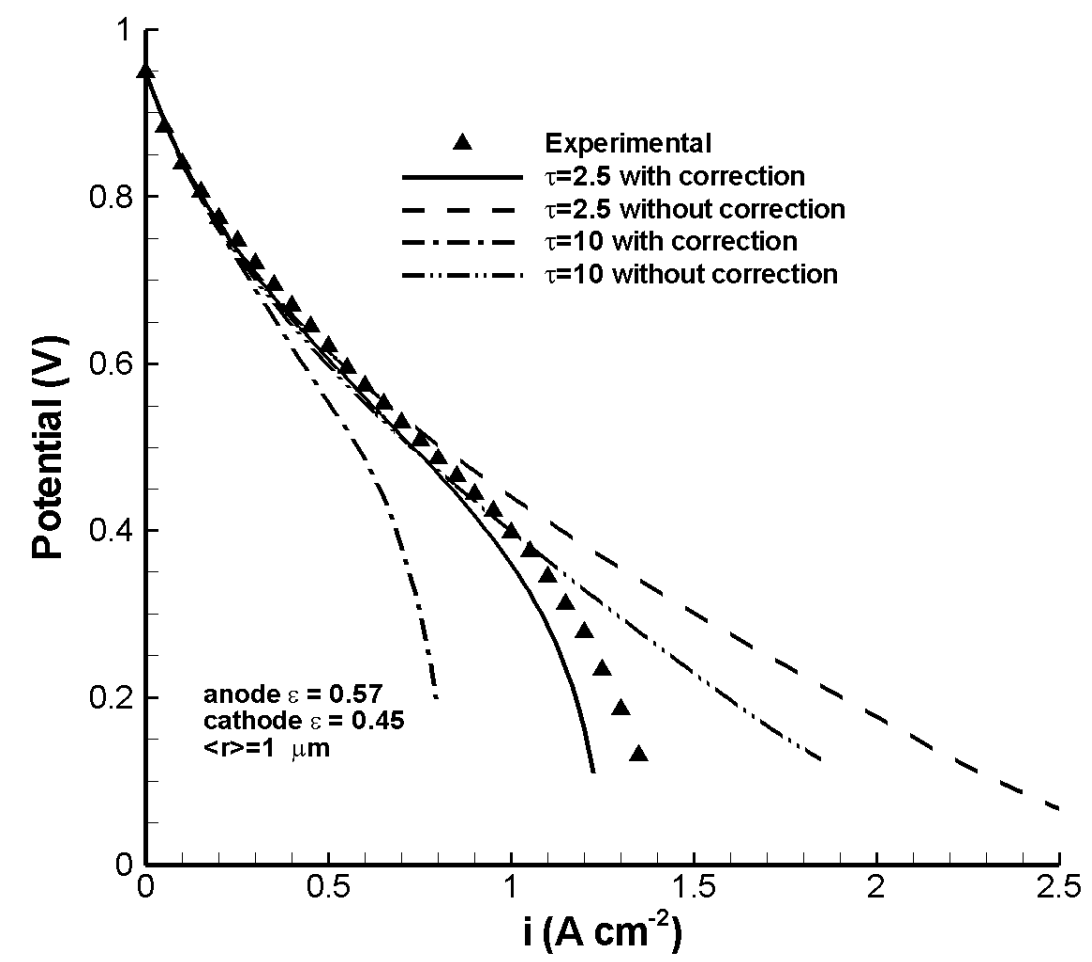

Figure 4. 6: Experimental and numerically simulated VI curves for the button cell

It can be seen from the figure that the agreement between the experiments and numerical predictions is good for low cell currents but at high currents the computations without correction to the diffusion coefficients fail to predict the onset of diffusion limitation of the cell performance. However the numerical results with corrected diffusion coefficients accurately predict the limiting current though the agreement in terms of voltage values is poor near the limiting current region of the VI curve. It should be noted that a reasonable value of $2.5[70,71]$ is used for tortuosity in these simulations. Though some researchers $[72,73]$ use higher values for tortuosity to calibrate diffusion limitation, they are not believed to be physically realistic $[70,74]$. For a thorough analysis, the simulations were repeated with a higher tortuosity of 10 with and without correction and the resulting VI curves are also plotted in Figure 6. It can be seen that, although the voltages for $\tau=10$ are lower than those for $\tau=2.5$, the curve does not show the typical drop in voltage at high currents when no correction was applied. When the correction was applied with $\tau=10$, 
the cell limiting current was found to be much lower than the experimentally observed value. It may thus be concluded that the inability of most numerical models to accurately predict the diffusion limitation is due to the inaccuracy resulting from Fick's law type diffusion model rather than the uncertainty in the tortuosity values. The limiting behavior is known to be due to the concentration of the reactants becoming very small near the active electrolyte/electrode interface.

\subsection{Summary and Conclusions}

Stefan-Maxwell Model (SMM) and simple Fick's Model (FM) type of relations both including Knudsen diffusion for the calculation of species mole fractions in a multicomponent systems were compared and it was found that at low current densities the models agree well but as current increases the differences also increase. Based on the findings an empirical correction is proposed for the effective diffusivity used in Fick's Model. The corrected diffusivity coefficient gave better agreement with the StefanMaxwell model and even at higher current densities the error is less than $5 \%$. As an application, an SOFC button cell which is being tested at West Virginia University was simulated. Numerical simulations with the corrected diffusivity accurately predicted the limiting current even with a reasonable tortuosity of 2.5. However, the predicted voltages were slightly different from the experimental values near the limiting current region. 


\section{CHAPTER 5- IMPURITY DEGRADATION MODEL}

This chapter describes the underlying mathematical relations used for modeling the degradation phenomena for the Ni-YSZ based SOFC anodes due to contaminants in coal syngas. In what follows, description of the model along with the model equations is presented. Calibration of the model and predictions using the calibrated model are presented in later sections of the chapter.

\subsection{Overview}

The performance and durability of SOFC operating on coal syngas is affected by the impurities such as phosphorus, arsenic, zinc, sulfur, mercury, selenium, and vanadium. It is difficult to completely remove these impurities and the clean-up processing could be very expensive. Therefore, it is imperative that fuels cell be tolerant to these impurities up to a certain level. While there are some experimental studies [18-20, 75-79] in the literature on the identification of impurities in coal syngas and their effects on the performance of Ni-Yttria stabilized Zirconia (Ni-YSZ) anode of SOFCs, tolerance limits for various impurities are not yet established. Present targets for levels of impurities in coal syngas for SOFC applications set by U.S. Department of Energy [80] are: total S < $60 \mathrm{ppbv}$, total halides $<100 \mathrm{ppbv}$, As $<5 \mathrm{ppbv}, \mathrm{Se}<0.2 \mathrm{ppmv}$ and $\mathrm{Cd}<30 \mathrm{ppbv}$. At low impurity concentrations, degradation rates are quite slow and long term experiments (more than $1000 \mathrm{~h}$ ) are required in order to determine the degradation rates in a cell [20]. Theoretical models that accurately predict the degradation behavior of SOFCs operating on syngas with very low levels of impurities could significantly reduce the time and 
effort involved in durability experiments. In order to formulate remedies for the undesirable effects of these impurities, it is necessary to understand the underlying mechanisms through which the cell performance has deteriorated.

In this study, a novel one-dimensional model is developed to predict the typical degradation patterns observed for contaminants such as P and As. It is widely reported that these species form secondary phases with $\mathrm{Ni}[21,29]$. The deposition of the impurity on the Ni catalyst starts near the fuel channel/anode interface and slowly moves toward the active anode/electrolyte interface. Figure 5.1 shows SEM images of the contaminant coverage along the anode thickness after $990 \mathrm{~h}$ of exposure to $\mathrm{PH}_{3}$ at different concentrations. It can be seen from the figure that upon exposure to the contaminants, there are two distinct regions of anode; one where the catalyst has formed secondary phases with the contaminant and one where the impurity has apparently not yet reached.
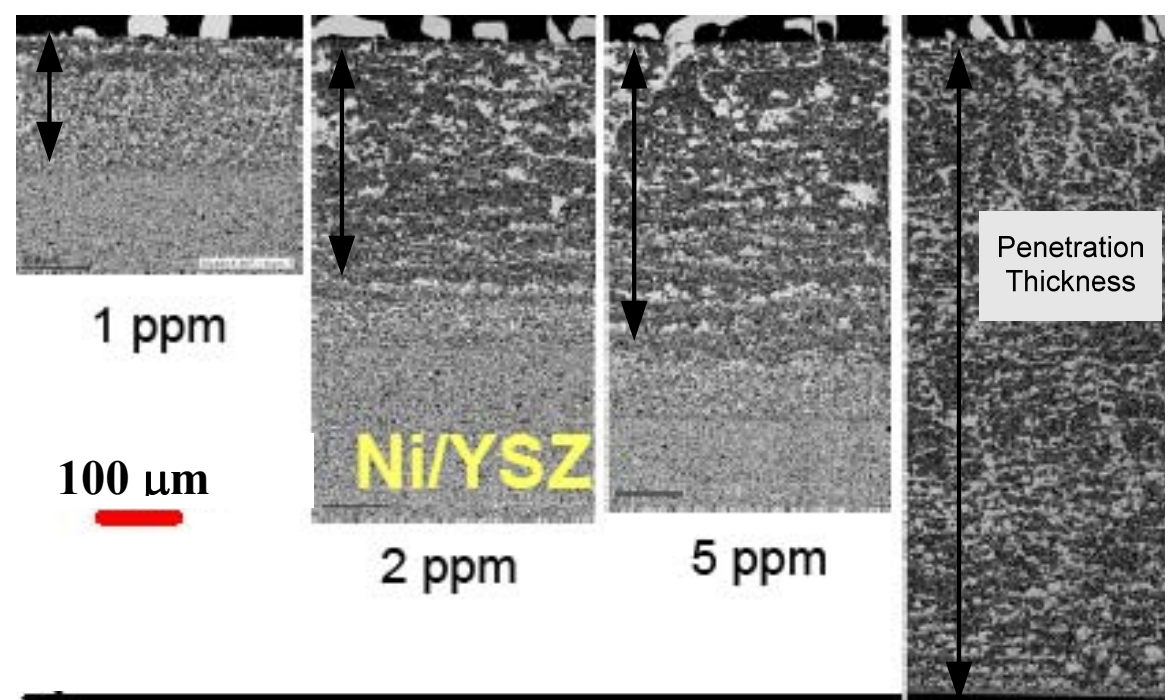

Anode/Electrolyte Interface

10 ppm

Figure 5. 1: Penetration thickness after $990 \mathrm{~h}$ with 1, 2, 5 and $10 \mathrm{ppm}$ of $\mathrm{PH}_{3}$ in coal syngas ([21], used with permission from PNNL) 
Figure 5.2 shows a typical performance degradation curve for an SOFC exposed to syngas with $\mathrm{H}_{2} \mathrm{Se}$ impurity. It should be noted that, in this study, to obtain a first-order comparison between the experimental results from various researches, a plot of the modified cell power density versus the operating time was used. The modified cell power density, $\mathrm{P}^{*}$, is defined by

$\mathrm{P}^{*}=\mathrm{P}_{\mathrm{ref}}-\left(\frac{P_{0}-P}{P_{0}}\right)$

where $\mathrm{P}_{\text {ref }}$ is the reference power density taken as $1, P_{0}$ is the power density at the time when the trace species is introduced and $P$ is the power density at any time.

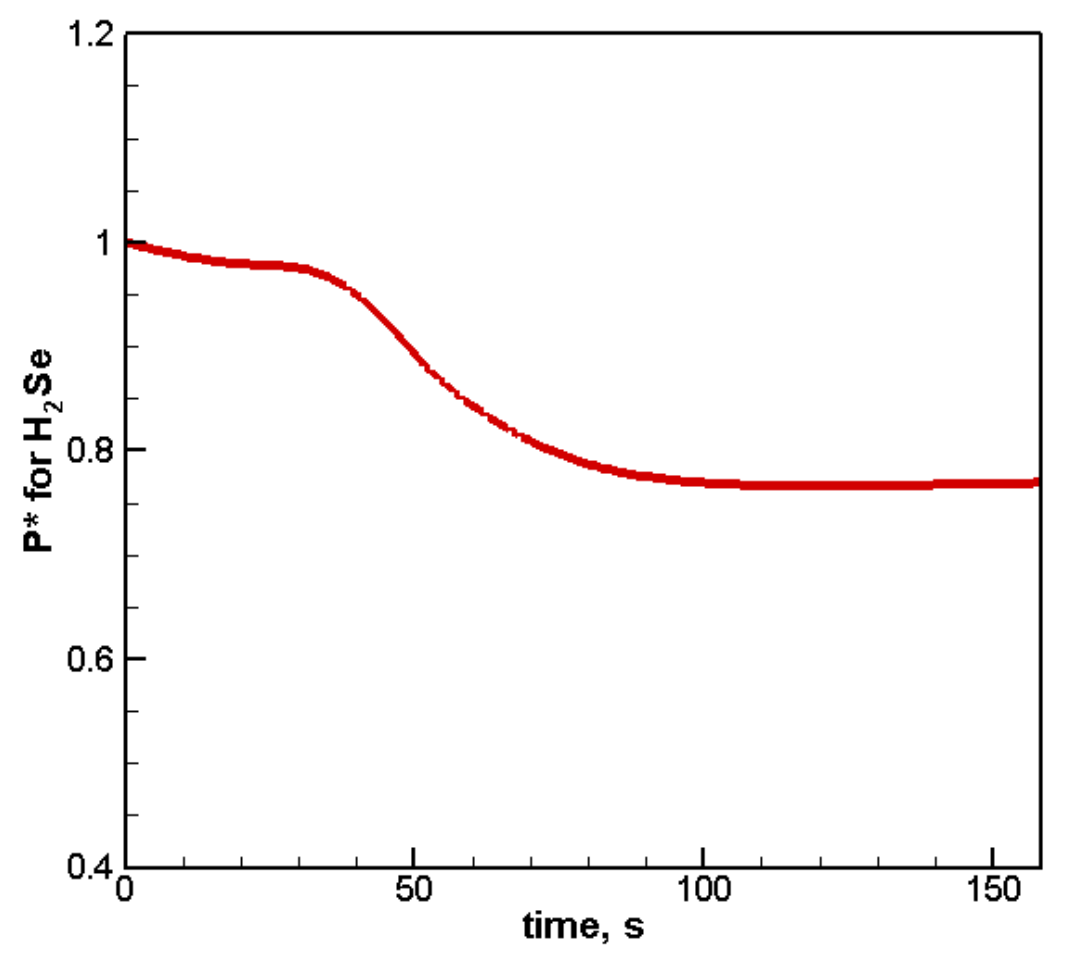

Figure 5. 2: Typical degradation curve for $1 \mathrm{ppm} \mathrm{H}_{2} \mathrm{Se}$ in coal syngas at $700{ }^{\circ} \mathrm{C}$ [81] As can be seen from the figure, performance degradation with time, in general, has four distinct stages, namely initial performance drop, intermediate slow degradation, second 
fast degradation and final slow degradation. It is postulated that four stages of typical degradation behavior can be correlated with the penetration of the catalyst secondary phase into the anode. Initial performance drop and intermediate slow degradation happen as the secondary phase front moves slowly toward the active interface. Eventually, when the front reaches the active interfaces, the catalyst at the active interface becomes deactivated leading to second fast degradation. After the catalyst is converted to the secondary phases to the maximum possible extent, the performance, if the cell is not completely dead, more or less stabilizes at a low value. The model presented in the current work attempts to capture the type of behavior discussed here both in terms of secondary phase formation and penetration and performance degradation.

The model includes gas diffusion including Knudsen diffusion and surface diffusion within the anode and the adsorption/desorption reactions on the surface of the Ni-YSZ based anode. The model parameters are calibrated to match the degradation rates reported in the literature.

Many details were disregarded to ensure model simplicity and applicability to many coal syngas impurities. However, the apparent subject complexity is still adequately represented by the resulting simplified model. Main assumptions made in the development of the model are:

- A competitive adsorption mechanism is assumed between the contaminant(s) and $\mathrm{H}_{2}$ gas.

- The base line cell performance degradation due to natural aging of cell materials is assumed to be small in comparison to the degradation caused by impurity effects on the anode.

- $\mathrm{CO}$ is not supporting the current production but it is indirectly contributing by augmenting the $\mathrm{H}_{2}$ supply through water gas shift reaction

- Interaction between the solid YSZ and the gas phase species is neglected since it is presumed that the degradation occurs due to secondary phase formation between the impurity species and the Ni catalyst.

- Diffusion like one-dimensional transport of coverages is assumed. 
- Monolayer adsorption mechanism is adopted.

- Local porosity and electrical conductivity are functions of local impurity coverage.

- Exchange current density is a function of impurity coverage at the active anode/ electrolyte interface.

\subsection{Model Equations}

The degradation model employed in this study considers the competitive adsorption of $\mathrm{H}_{2}$ and the typical impurity $\mathrm{X}$ on the surface of $\mathrm{Ni}$ catalyst. The proposed monolayer adsorption mechanism is given by:

$$
\begin{aligned}
& X+N i \underset{k_{b, X}}{\stackrel{k_{f, X}}{\rightleftharpoons}} \mathrm{Ni}-X \\
& \mathrm{H}_{2}+2 N i \stackrel{k_{f, H}}{\underset{k_{b, H}}{\rightleftharpoons}} 2(\mathrm{Ni}-\mathrm{H})
\end{aligned}
$$

This mechanism is called monolayer adsorption mechanism since it is assumed that once an active catalyst site is taken up by either $\mathrm{H}_{2}$ or contaminant $X$, it is not accessible for other species until it is released by the original occupying species. Also in the model, the sites that are covered by $X$ and are not subsequently released are assumed to eventually form secondary phases. The composition and nature of the secondary phases are not resolved by this model.

Based on the observation that the front of the coverage moves with time, a one dimensional phenomenological transport equation for the coverage (of species i) propagation along the thickness of the anode can be written as:

$$
\frac{\partial \theta_{i}}{\partial t}=D_{\theta} \frac{\partial^{2} \theta_{i}}{\partial z^{2}}+\omega_{\theta_{i}}
$$


where $\theta_{i}$ is a progress variable here representing the surface coverage for species $i$ which is defined as the fraction of the catalyst sites that is covered by the adsorbed species. $D_{\theta}$ is the transport coefficient for the progress variable and taken as $1 \times 10^{-9} \mathrm{~m}^{2} / \mathrm{s} . \omega_{\theta_{i}}$ denotes the source terms due to the reactions given in Eq.s (5.2) and (5.3), that is

$$
\begin{aligned}
& \omega_{\theta_{X}}=k_{f, X} y_{X} \theta_{N i}-k_{b, X} \theta_{N i-X} \\
& \omega_{\theta_{N i-H}}=k_{f, H} y_{H_{2}} \theta_{N i}^{2}-k_{b, H} \theta_{N i-H}^{2}
\end{aligned}
$$

where $k_{f}$ and $k_{b}$ are the forward and backward reaction rate constants. $y_{i}$ is mole fraction of the species $i$. As a further constraint the surface coverages for the contaminant, hydrogen and nickel must add up to 1 :

$\theta_{N i-X}+\theta_{N i-H}+\theta_{N i}=1$

The diffusion constant and the forward and backward reaction rate constants for the impurity adsorption in Eq.s (5.5), (5.6) and (5.7) are the parameters that need to be estimated using the available experimental data.

Source terms found from Eq.s (5.5) and (5.6) are used to calculate the gas phase concentration distribution along the thickness of the anode from one-dimensional species conservation equation for porous media given by:

$$
\varepsilon \frac{P}{R T} \frac{\partial y_{i}}{\partial t}=\frac{\partial}{\partial z}\left(\frac{P}{R T} D_{i}^{e f f} \frac{\partial y_{i}}{\partial z}\right)+R_{i}+S_{i}
$$

where $D_{i}^{\text {eff }}$ is the effective diffusivity for species $i$ in the mixture including both Knudsen and binary diffusivities detailed calculation of which is given in Chapter 4.2. $R_{i}$ is the molar rate of productions of species $i$ due to water gas shift and methane steam reforming reactions defined by Eqs. (4.16) and (4.17). Since adsorption of the contaminant on the catalyst eventually forms secondary phases that cause morphological changes thereby 
reducing the pore sizes, it is postulated that local porosity, and hence the effective diffusivity, is a function of local contaminant coverage via

$\varepsilon=\varepsilon_{0}\left(1-\theta_{N i-X}\right)^{p}$

where $\varepsilon_{0}$ is the porosity at zero contaminant coverage.

$S_{i}$ in Eq. (5.8) is the net production rate of species $i$ which is calculated from:

$S_{i}=\dot{\omega}_{\theta_{\mathrm{i}}} \Gamma \mathrm{a}_{\mathrm{s}}$

The site density, $\Gamma,\left(\mathrm{mol} / \mathrm{m}^{2}\right)$ is the number of active catalyst sites per unit interfacial area between the solid and gas phases of the porous electrode and specific catalyst area and, $a_{s},(1 / m)$ is the ratio of interfacial area per unit volume of the anode. These two parameters are obtained from literature [82] and are taken as $\Gamma=2.6 \times 10^{-5} \mathrm{~mol} / \mathrm{m}^{2}$ and $\mathrm{a}_{\mathrm{s}}=$ $2.0 \times 10^{5} \mathrm{~m}^{-1}$.

Performance curve is obtained by subtracting the voltage losses, i.e. overpotentials, from the theoretical Nernst voltage. Nernst voltage is calculated from

$$
E_{N}=-\frac{\Delta G^{o}}{2 F}-\frac{R_{u} T}{2 F} \ln \left[\frac{y_{\mathrm{H}_{2} \mathrm{O}}}{y_{\mathrm{H}_{2}} y_{\mathrm{O}_{2}}^{1 / 2}}\right]
$$

where, $F$ is the Faraday's constant, $R_{u}$ is universal gas constant, $T$ is the temperature, and $y_{\mathrm{H}_{2}}$ and $y_{\mathrm{H}_{2} \mathrm{O}}$ are the mole fractions of hydrogen and water vapor on the anode side and $y_{\mathrm{O}_{2}}$ is the mole fraction of oxygen on the cathode side. $\Delta G^{o}$ is the Gibbs function for oxidation of hydrogen

$$
\mathrm{H}_{2}+\frac{1}{2} \mathrm{O}_{2} \rightarrow \mathrm{H}_{2} \mathrm{O}
$$


Concentration overpotential or mass transfer loss due to bulk diffusion resistance is given as:

$\eta_{\text {diff }}=\frac{R_{u} T}{2 F} \ln \left[\frac{P_{H_{2}}^{A / E}}{P_{H_{2}}^{A / F}} \frac{P_{H_{2} \mathrm{O}}^{A / F}}{P_{H_{2} \mathrm{O}}^{A / E}}\right]$

where $P_{i}$ is the partial pressure of the species $i$. Subscripts $\mathrm{A} / \mathrm{E}$ and $\mathrm{A} / \mathrm{F}$ denote the anode/fuel channel and anode/electrolyte interfaces, respectively.

Activation loss due to adsorption of contaminant on the active sites for electrochemical reactions is calculated from Butler-Volmer equation with the assumption that the transfer coefficient $\alpha$ is 0.5

$\eta_{a c t}=\left[\frac{2 \alpha F}{R_{u} T}\right]^{-1} \sinh ^{-1}\left(\frac{i_{H_{2}}}{2 i_{o, H_{2}}}\right)$

where $i_{\mathrm{H}_{2}}$ is the current density. Exchange current density, $i_{o, H_{2}}$ is usually a function of temperature and the hydrogen activity at the active interface. Here it is postulated that the catalyst deactivation at the interface due to contaminant coverage will also affect the exchange current density. The proposed equation to model the combined effect is given by

$i_{o, H_{2}}=C_{1}\left(\frac{y_{H_{2}, \text { int }}}{y_{H_{2}, \text { ref }}}\right) \exp \left(-\frac{E_{a c t, H_{2}}}{R_{u} T}\right)\left(1-\theta_{N i-X, \text { int }}^{m}\right)^{n}$

where the reference concentration, $y_{H_{2}, \text { ref }}$, is 0.333 , the activation energy barrier, $E_{a c t, H_{2}}$, is $91.661 \mathrm{~kJ} / \mathrm{mol}$, and the constant $c_{1}$ is $3.936 \times 10^{7}$ [83]. Subscripts $m$ and $n$ are the model parameters obtained from calibration with the experimental data. Use of a power law type of relation in Eq.(5.15) may seem like an arbitrary choice with no chemical or physical reasoning .However, this type of curve fit used in this engineering model is the 
best option for capturing all four stages of the typical degradation curve shown in Figure 5.2. Similar approaches are widely used in the literature, for example, as in the case of using Arrhenius type of relation for explaining the temperature dependence of the chemical reaction rate constants.

The charge conservation equation is written as

$$
\frac{1}{c} \frac{\partial \phi}{\partial t}=0=\frac{\partial}{\partial z}\left(\sigma \frac{\partial \phi}{\partial z}\right)
$$

Since formation of secondary phases alters the electrical conductivity, $\sigma$, of the anode, it can be modified and written as a function of the local contaminant coverage:

$$
\sigma=\sigma_{0}\left(1-\theta_{N i-X}\right)^{q}
$$

where $\sigma_{0}$ is the electrical conductivity at zero percent coverage of the contaminant. Subscript $q$ is a model parameter determined via calibration with the experimental data. Again a similar reasoning apply in selection of this power law as that in Eq. (5.15).

Eq.(5.16) is solved with the following boundary conditions:

1) At Anode/Fuel Channel Interface: $\phi=0$

2) At Anode/Electrolyte Interface: $-\sigma \frac{\partial \phi}{\partial z}=i$

where $i$ is the current density. Ohmic loss in the anode resulting from electrical conduction loss due to adsorption of the contaminant thereby changing the conductive properties of the catalyst surface is then calculated as

$$
\eta_{\text {ohm }}=\Delta \phi_{\text {anode }}
$$


Here $\Delta \phi_{\text {anode }}$ is the potential difference across the anode.

\subsection{Numerical Method}

The numerical model integrates the one-dimensional unsteady diffusion Eqs. (5.4) and (5.8) using finite volume method. The diffusion terms are advanced implicitly by CrankNicholson scheme whereas the source terms are treated fully explicitly. The diffusion terms are spatially discretized using second order central differencing scheme. The onedimensional computational domain measures from 0 to $\mathrm{L}$ where $\mathrm{L}$ is the anode thickness. The simulations were run on a uniformly distributed grid typically composed of 19 cells with a typical constant time step $\Delta t$ of $1 \times 10^{-5} \mathrm{~s}$.

At the upper and lower boundaries corresponding to anode/fuel channel and anode/electrolyte interfaces, respectively, zero-flux boundary conditions were imposed for coverages in Eq. (5.4). As for Eq. (5.8), constant molar fluxes proportional to the prescribed cell current are employed at anode/electrolyte interface. At the anode/fuel channel boundary, the diffusive flux is set equal to the convective flux given by

$$
-\left.D_{i}^{e f f} \frac{\partial y}{\partial z}\right|_{z=0}=k_{m}\left(y_{\infty}-y_{\text {surface }}\right)
$$

where $y_{\infty}$ is the free stream concentration at the fuel channel, $y_{\text {surface }}$ is the surface concentration at the cell wall. $k_{m}$ is the mass transfer coefficient calculated from Sherwood number $\left(\mathrm{Sh}=k_{m} \delta / \mathrm{D}^{\mathrm{eff}}\right)$ estimated from realistic simulations. 


\subsection{Model Calibration}

In this section, the procedure used for calibrating the model parameters is summarized. A trial and error method was utilized for calibration. However, the procedure is not trivial and does not depend on pure luck; on the contrary, educated guesses were made by making use of a priori investigations on the effect of each model parameter on the interface contaminant coverage and thus the performance degradation.

In an attempt to determine the effect of model parameters such as effective diffusivity of the contaminant, $D_{X}^{\text {eff }}$, and the forward rate constant for the contaminant adsorption reaction, $k_{f, x}$, on performance degradation, a parametric study is conducted. In the present study, electrolyte supported cells with anode thickness of approximately $30 \mu \mathrm{m}$ were considered since they provide more rapid results due to smaller nickel inventory. The assumed anode electrode is made of a $56 \%$ porosity cermet with a reasonable tortuosity of 3.6.

A base case was selected using the model parameters listed in Table 5.1. A hypothetical contaminant $X$ with $10 \mathrm{ppm}$ concentration in a simulated coal syngas containing $23 \% \mathrm{CO}$, $30 \% \mathrm{H}_{2}, 21 \% \mathrm{CO}_{2}$ and $26 \% \mathrm{H}_{2} \mathrm{O}$ is used. All simulations were done at atmospheric pressure. For the comparison purposes a dimensionless group, namely Thiele modulus, was utilized. This number is defined as the ratio of reaction and diffusion timescales and given as

$\Pi=\frac{\left(1 / k_{f, X}\right)}{\left(\delta^{2} / D_{X}^{e f f}\right)}=\frac{D_{X}^{e f f}}{\delta^{2} k_{f, X}}$

where $\delta$ is the anode thickness, $k_{f, X}$ is the forward reaction rate constant for impurity adsorption reaction and $D_{X}^{\text {eff }}$ is the effective diffusivity of the impurity species. The combined effect of contaminant effective diffusivity and forward reaction rate constant was investigated using this dimensionless number. The reason for selecting a 
dimensionless group is that decreasing effective diffusivity instead of increasing forward rate constant is numerically less cumbersome since increased forward rate constants results in bigger source terms for the governing equation (Eq.(5.4)) making it stiffer. Smaller time steps were required in order to solve that equation. On the other hand, decreasing effective diffusivity does not affect the time step utilized and the end results are the same as long as the Thiele modulus is kept constant.

Table 5. 1: Parameters used for the parametric analysis

\begin{tabular}{|l|l|}
\hline \multicolumn{1}{|c|}{ Parameter } & \multicolumn{1}{c|}{ Value } \\
\hline Temperature, ${ }^{\circ} \mathrm{C}$ & 800 \\
\hline Current density, A/cm ${ }^{2}$ & 0.5 \\
\hline$D_{X}^{e f f}, \mathrm{~m}^{2} / \mathrm{s}$ & $1 \times 10^{-6}$ \\
\hline$k_{f, X}, \mathrm{~s}^{-1}$ & 0.5 \\
\hline $\mathrm{m}$ & 0.4 \\
\hline $\mathrm{n}$ & 7.0 \\
\hline $\mathrm{p}$ & 2.0 \\
\hline $\mathrm{q}$ & 2.0 \\
\hline
\end{tabular}

The effect of increasing Thiele modulus by 2.5 times or reducing it by 0.5 times on the interface coverage and the performance degradation due to the hypothetical contaminant $X$ are shown in Figure 5.3 and 5.4, respectively. As can be seen from Figure 5.3, increasing the dimensionless number (by 2.5 times) decreases the time for the front to reach the active interface. In other words, increasing the contaminant effective diffusivity or decreasing the forward reaction rate constant speeds up the starting of contaminant coverage at the interface. It is also worth mentioning that, once the front reaches the active interface, the time evolution is very similar for each case. Comparing Figure 5.3 and 5.4 reveals that, since time evolution of the interface coverage is the same after the active interface is reached, the form of the performance curves are the same. The only 
difference is the cell failure time which increases with the decreasing Thiele modulus. It is also observed that, there is a linear relationship between the values of the Thiele modulus and the cell failure time, i.e., decreasing Thiele modulus in half, doubles the cell failure time.

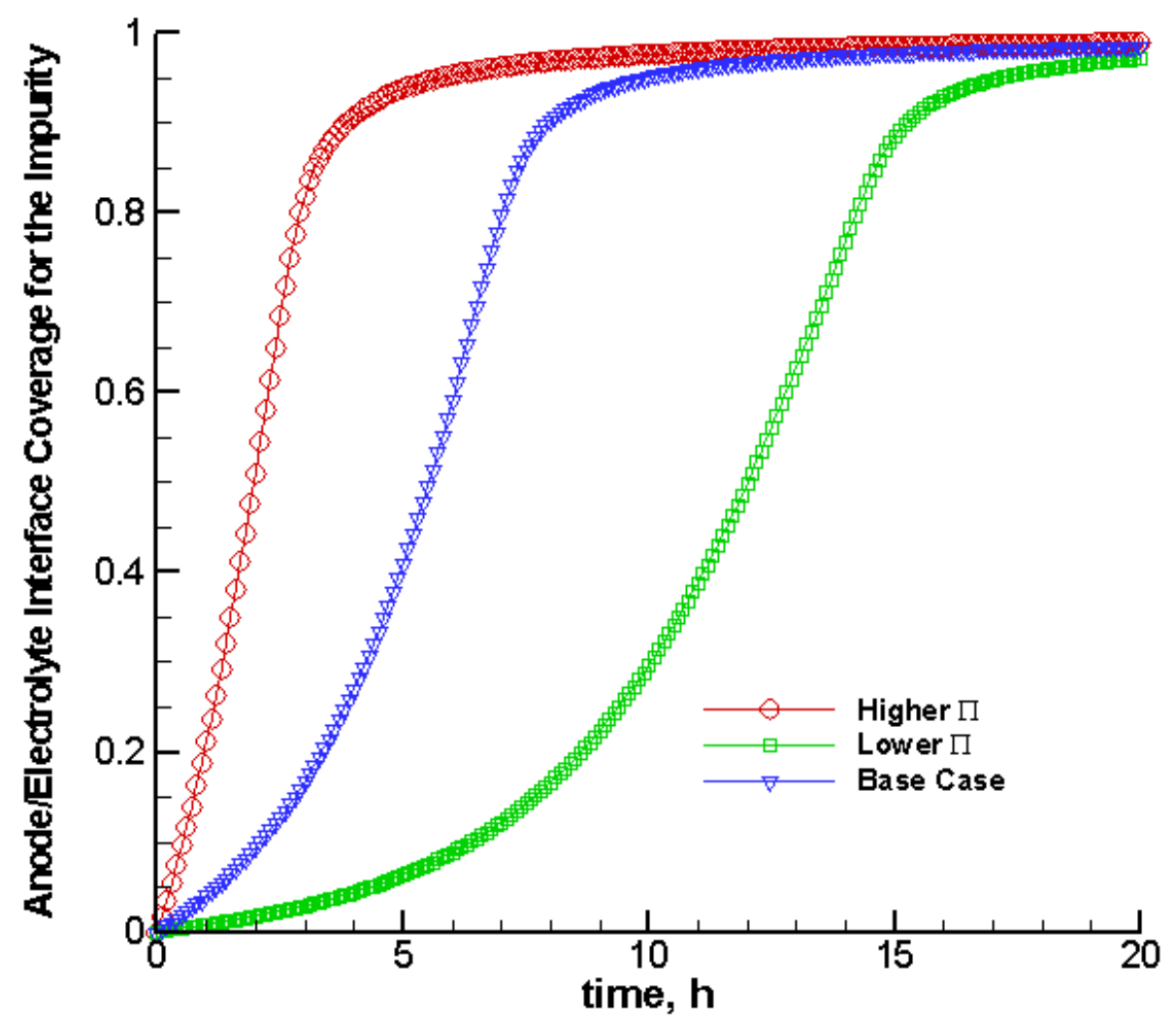

Figure 5. 3: Effect of Thiele modulus on the interface coverage for the impurity $X$. 


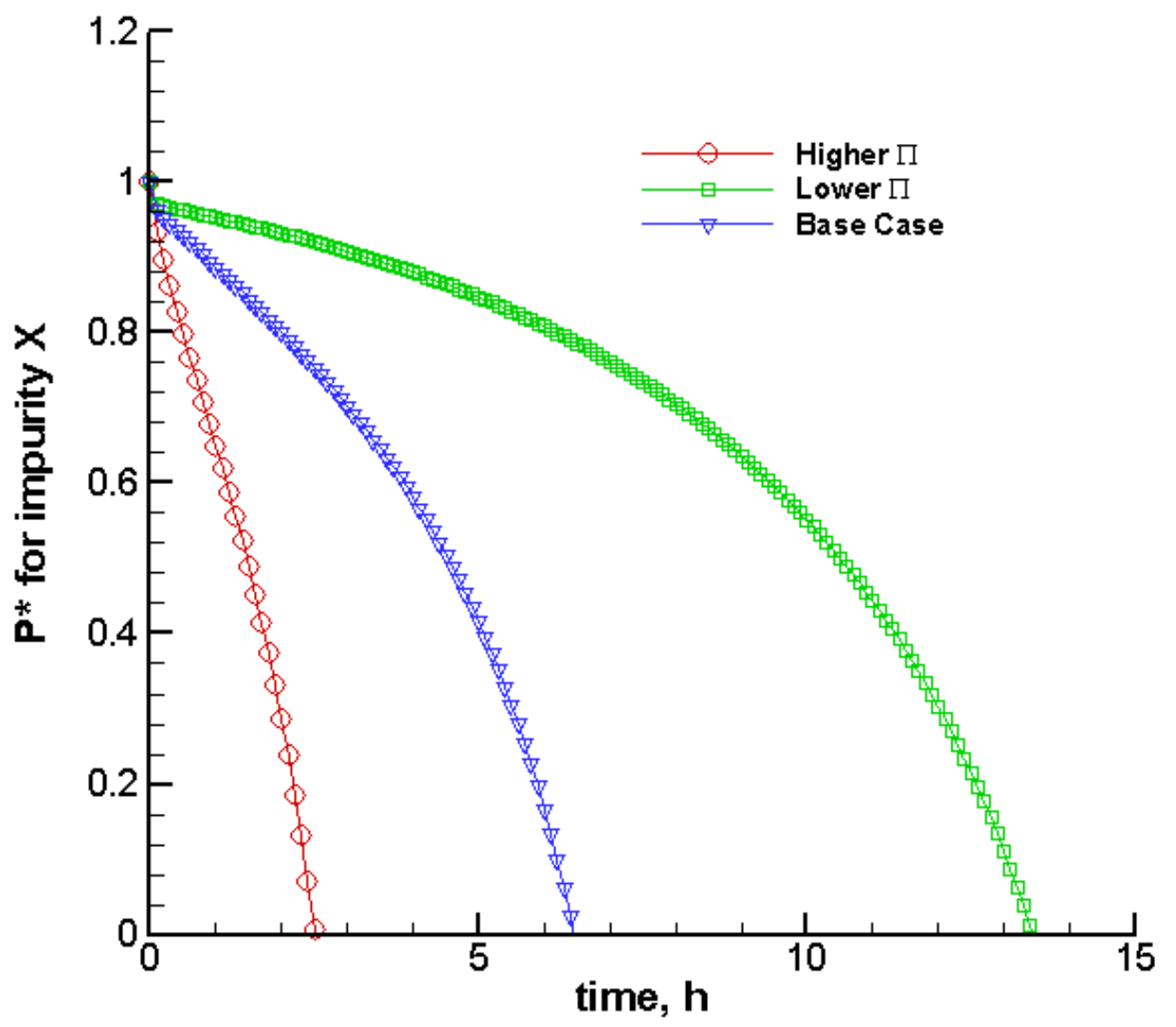

Figure 5. 4: Effect of Thiele modulus on the modified power density for the impurity $X$.

Figures 5.5 and 5.6 show the effect of Thiele modulus on the anode surface concentration and the flux of impurity $X$, respectively. From Figure 5.5, it is seen that the time to reach the free stream impurity concentration decreases with increasing Thiele modulus. Once the surface concentration reaches the free stream value, the flux at the anode/fuel channel interface becomes zero, as can be seen from Figure 5.6. 


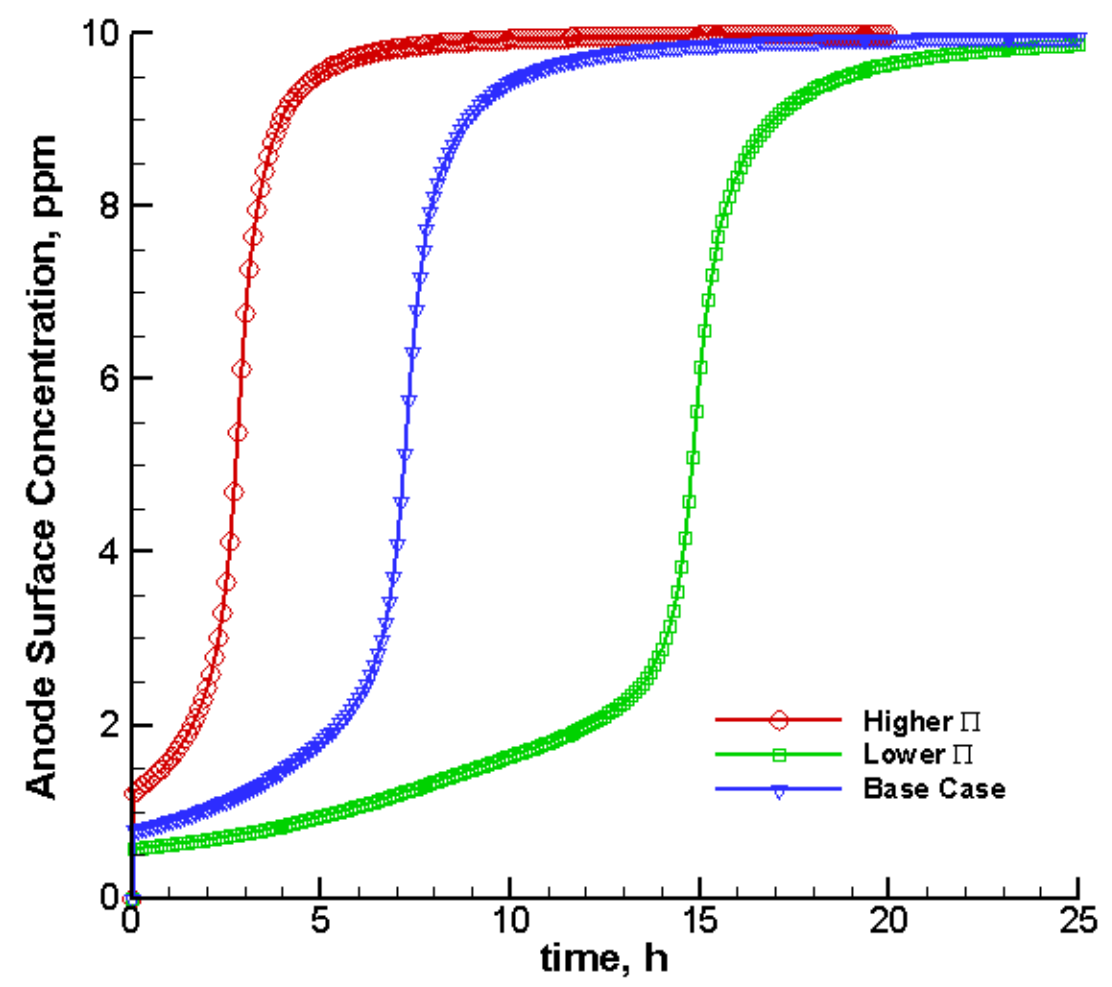

Figure 5. 5: Effect of Thiele modulus on the anode surface concentration of impurity $X$ 


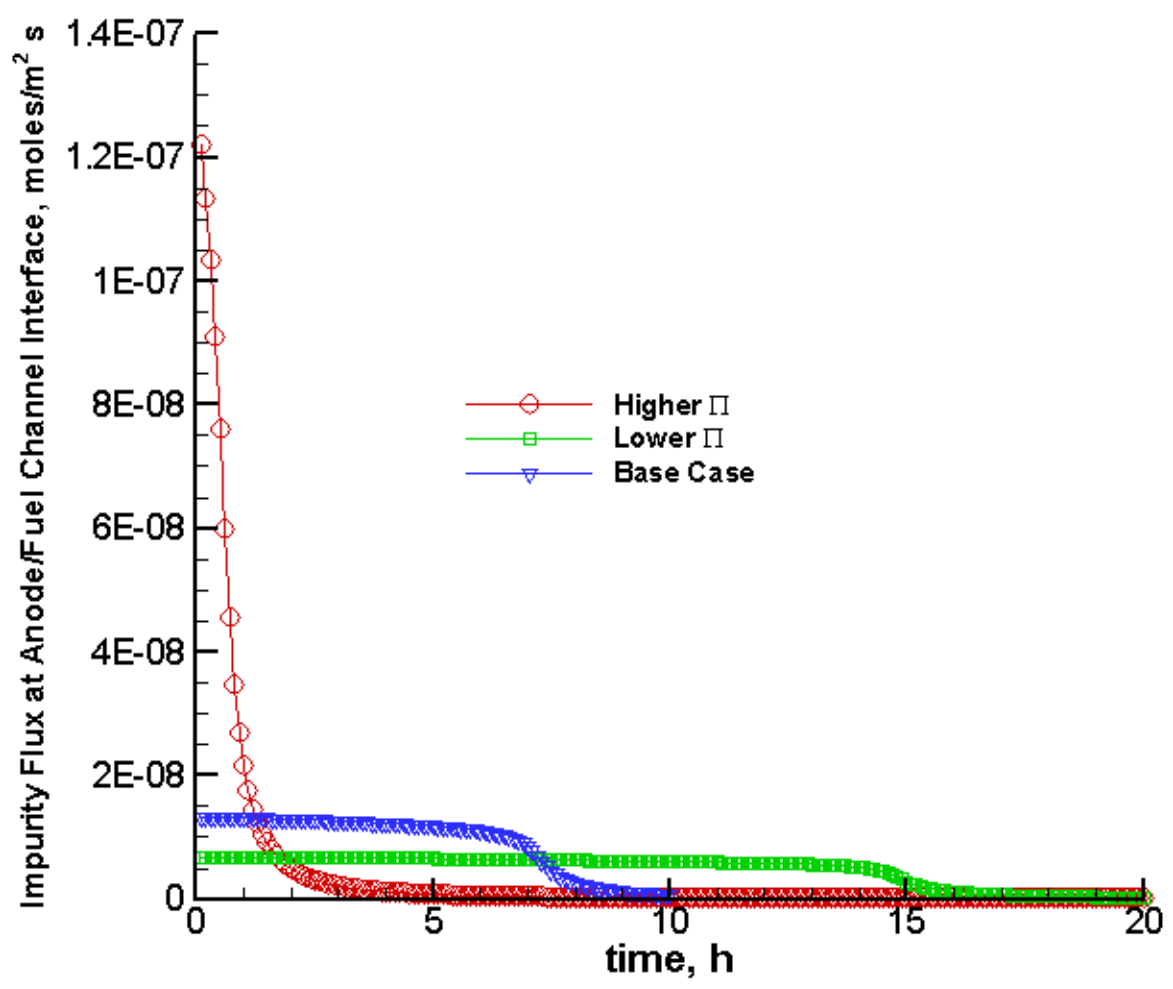

Figure 5. 6: Effect of Thiele modulus on the impurity flux at the anode/fuel channel interface

In addition, a sensitivity analysis was performed to determine the effect of powers $m$ and $n$ appearing in Eq. (5.15). These parameters control the dependence of the exchange current density for $\mathrm{H}_{2}$ on the interface impurity coverage and thus the behavior of performance degradation. Figures 5.7 (a) and 5.7 (b) show the variation of performance degradation curve with the powers $m$ and $n$, respectively. The base case calculations were carried out using the parameters tabulated in Table 5.1.

It can be seen from Figure 5.7 (a) that as the value of power $m$ is increased all four stages of the typical performance degradation become evident. In addition, decreasing the power $m$ leads to faster degradation of the cell without observing the third stage of the performance degradation. Similarly, increasing power $n$, leads to a performance curve 
with all four stages of degradation with slightly higher initial degradation (see Figure 5.7 (b)).

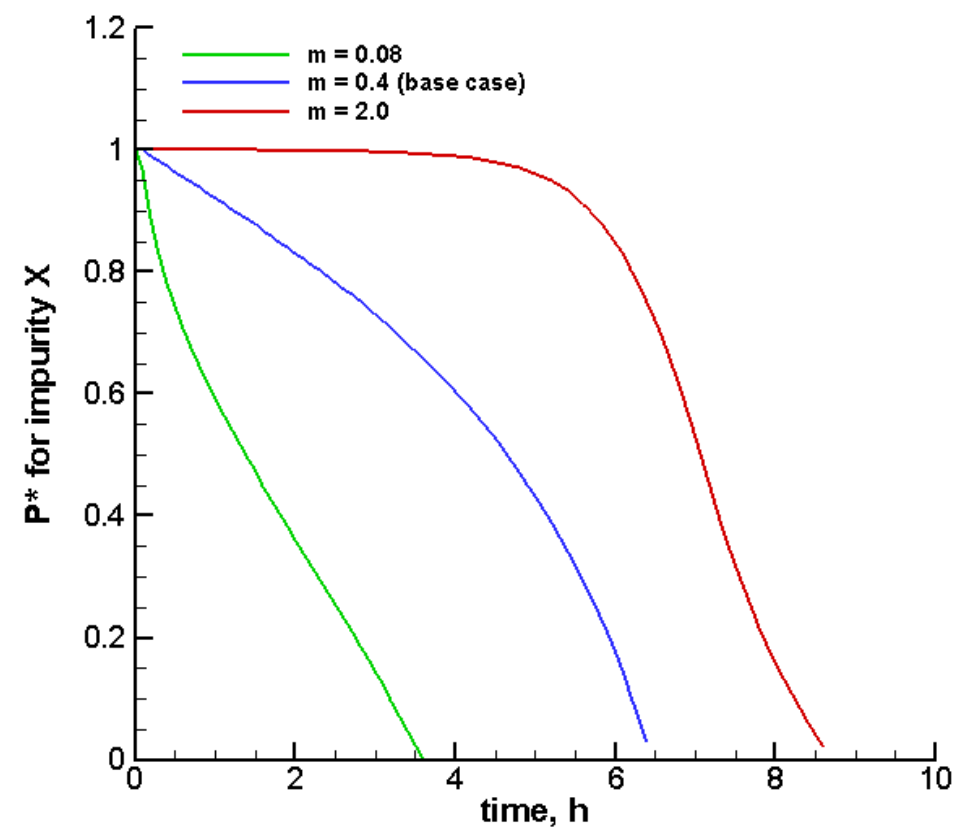

(a)

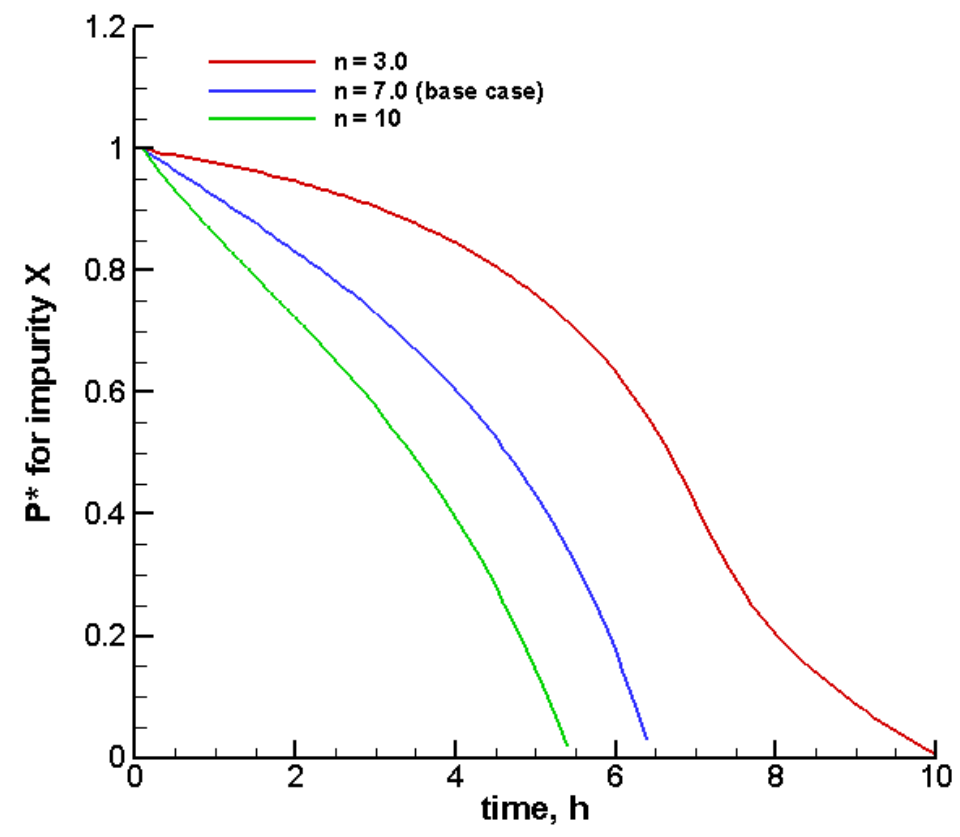

(b)

Figure 5. 7: Variation of performance degradation with model parameters (a) m, (b) $n$ 
Making use of these observations discussed, the calibration for $\mathrm{AsH}_{3}, \mathrm{PH}_{3}, \mathrm{H}_{2} \mathrm{~S}$ and $\mathrm{H}_{2} \mathrm{Se}$ were done by minimizing the difference between the performance degradation curves obtained form the current model and the experimental results for electrolyte-supported cells. Initial task in calibration process is to match the timescale for the front to reach the active interface. This time scale is adjusted by changing the effective diffusivity, keeping in mind that increasing it results in smaller time to reach the active interface and hence faster initial degradation (see Figure 5.3 for higher Thiele modulus). Second fast degradation and the final slow degradation stages in the performance degradation curve is governed by the powers $m$ and $n$ appearing in the exchange current density relation given in Eq. (5.15). These parameters are adjusted according to the sensitivity analysis described above. The model parameters $p$ and $q$ in equations (5.9) and (5.17) are increased to catch the initial fast drop in performance typically observed for $\mathrm{H}_{2} \mathrm{~S}$. For other impurity species, their values are the same and taken as 2.0.

\subsection{Results and Discussion}

\subsubsection{Arsine}

Calibration for $10 \mathrm{ppm} \mathrm{AsH}_{3}$ in a simulated coal syngas containing 23\% CO, 30\% $\mathrm{H}_{2}$, $21 \% \mathrm{CO}_{2}$ and $26 \% \mathrm{H}_{2} \mathrm{O}$ was done by minimizing the difference between the performance curves obtained from the current model and the experimental results from Coyle et al. [22] and the result is given in Figure 5.8. Experiments were conducted at $800^{\circ} \mathrm{C}$ with a constant current density of $0.05 \mathrm{~A} / \mathrm{cm}^{2}$. 


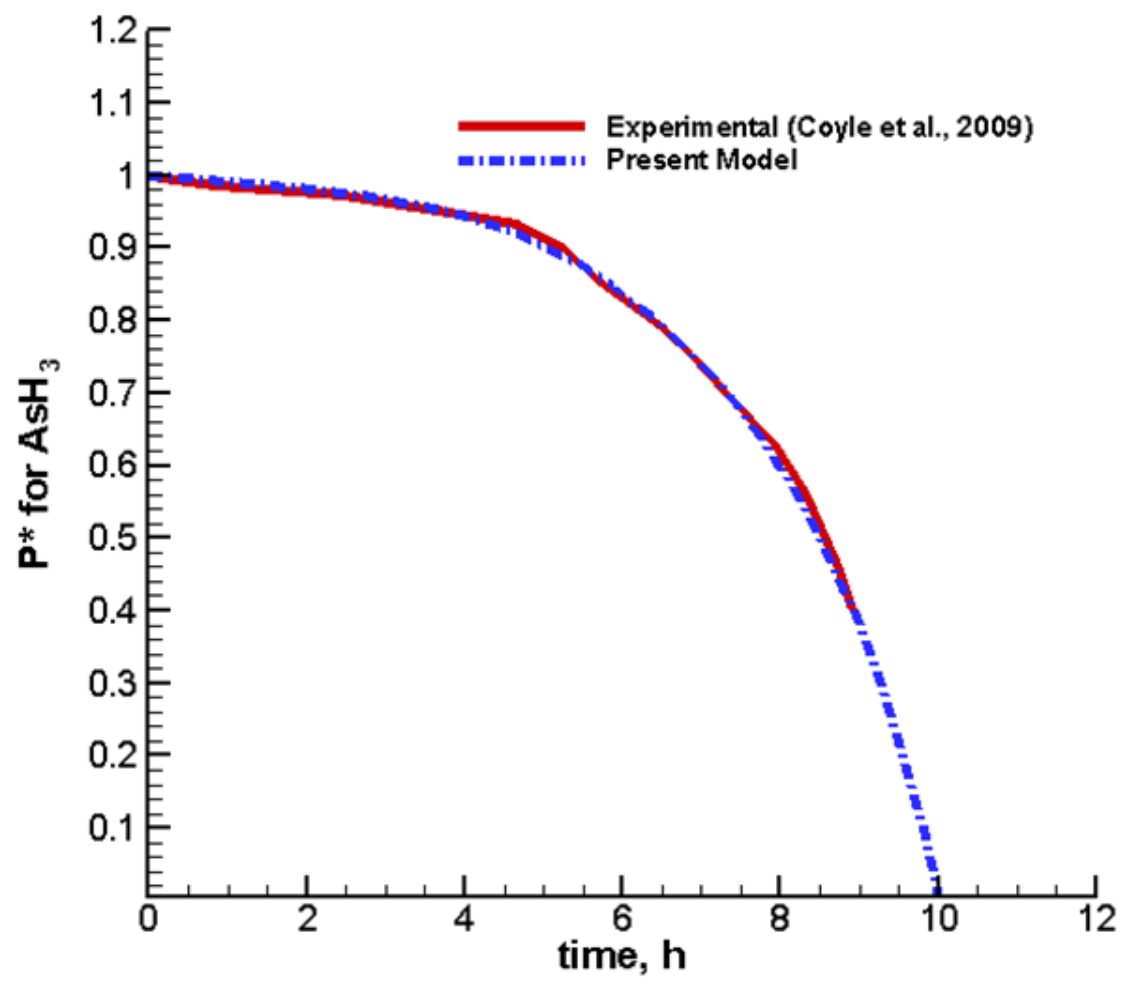

Figure 5. 8: Calibration of modified power density against experimental data adopted from Coyle et al. [22] for $10 \mathrm{ppm} \mathrm{AsH}_{3}$ in coal syngas at $800{ }^{\circ} \mathrm{C}$

It is seen from the Figure 5.8, it is possible to obtain a good agreement between the experimental data and the model results. The calibrated parameters are listed in Table 5.2.

Table 5. 2: Calibrated parameters for $\mathrm{AsH}_{3}$ impurity

\begin{tabular}{|l|l|}
\hline \multicolumn{1}{|c|}{ Parameter } & \multicolumn{1}{c|}{ Value } \\
\hline$k_{f, X}, \mathrm{~s}^{-1}$ & $5.0 \times 10^{3} \exp (-5.97 / \mathrm{RT})$ \\
\hline$k_{b, X}, \mathrm{~s}^{-1}$ & $9.1 \times 10^{-1} \exp \left(-9.27 \times 10^{4} / \mathrm{RT}\right)$ \\
\hline$m$ & 0.3 \\
\hline$n$ & 6.5 \\
\hline$p$ & 2.0 \\
\hline$q$ & 2.0 \\
\hline
\end{tabular}


Figures 5.9 and 5.10 show the interface coverage and the time evolution of the coverage inside the anode for arsine, respectively. It should be noted that the fourth stage of performance degradation was not observed here (see Fig 5.8) since once the contaminant coverage reaches a certain value at the interface the cell dies without stabilizing the performance. It can be seen from Figure 5.10 shows that there exists a distinct region between the covered and yet to be covered parts of the anode at different times of the simulation.

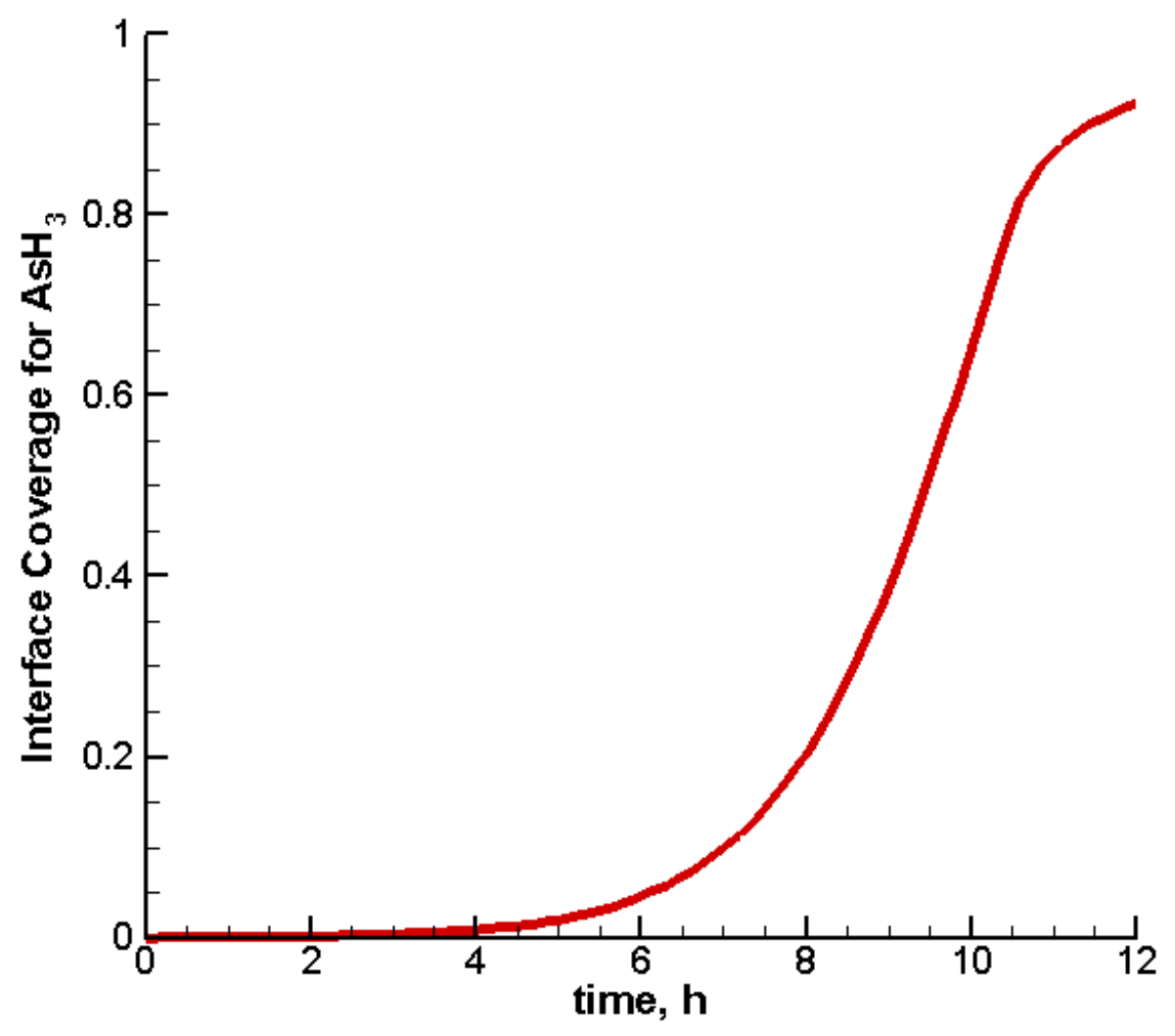

Figure 5. 9: Time evolution of the interface coverage for $\mathrm{AsH}_{3}$ impurity 


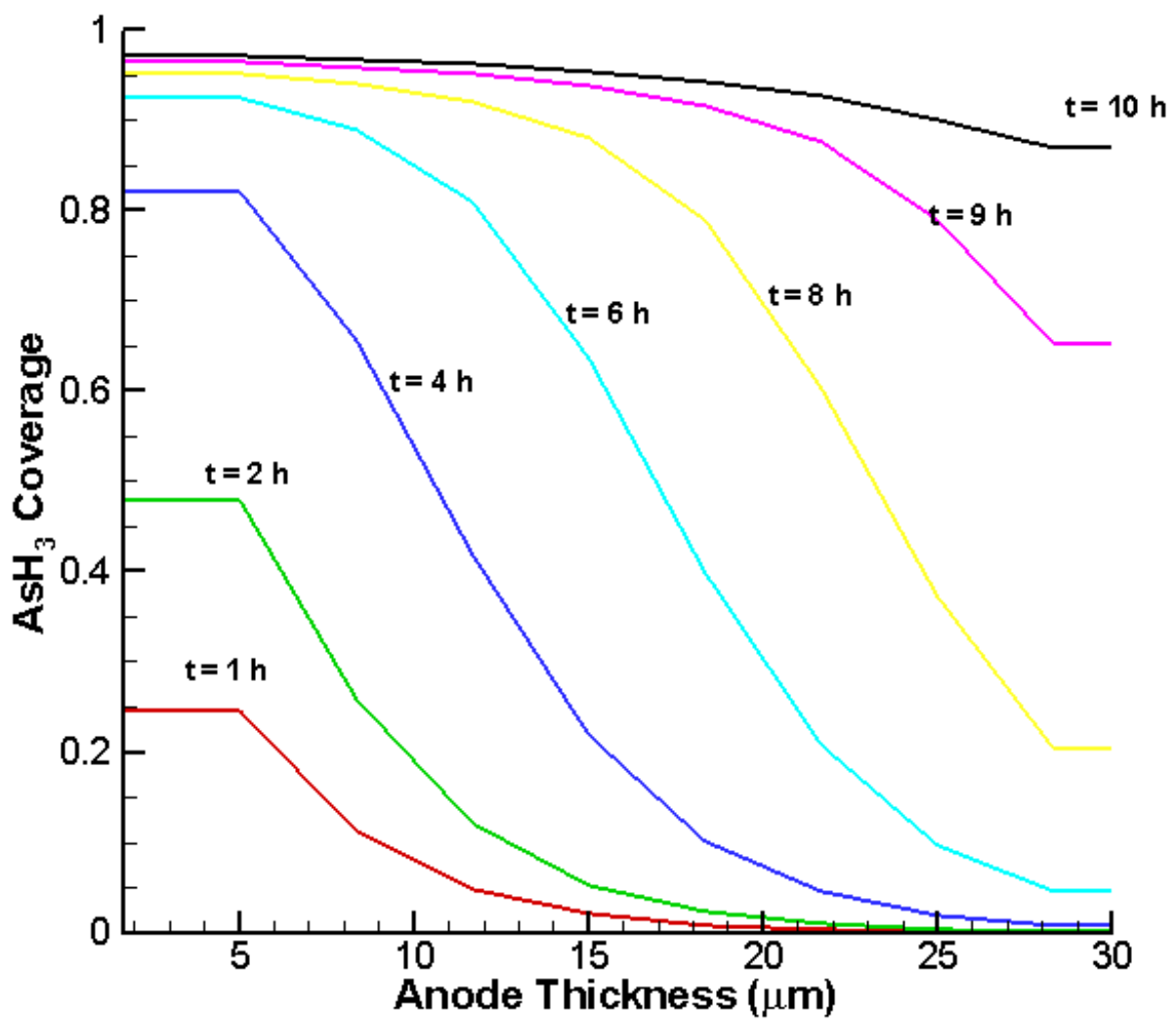

Figure 5. 10: Coverage profile for $\mathrm{AsH}_{3}$ at different times

The space maps of porosity and electrical conductivity along with the exchange current density at different times was also shown in Figures 5.11, 5.12 and 5.13, respectively. It is clearly seen from the figures that as the available nickel sites available for $\mathrm{H}_{2}$ adsorption are covered by the impurity over time, the porosity and electrical conductivity decreases as well as the exchange current density at the active anode/electrolyte interface. Therefore, according to the developed model, the performance degradation is due to a combined effect of reduced porosity and electrical conductivity and the deactivated electrochemical reactions due to impurity adsorption on the nickel catalyst. 


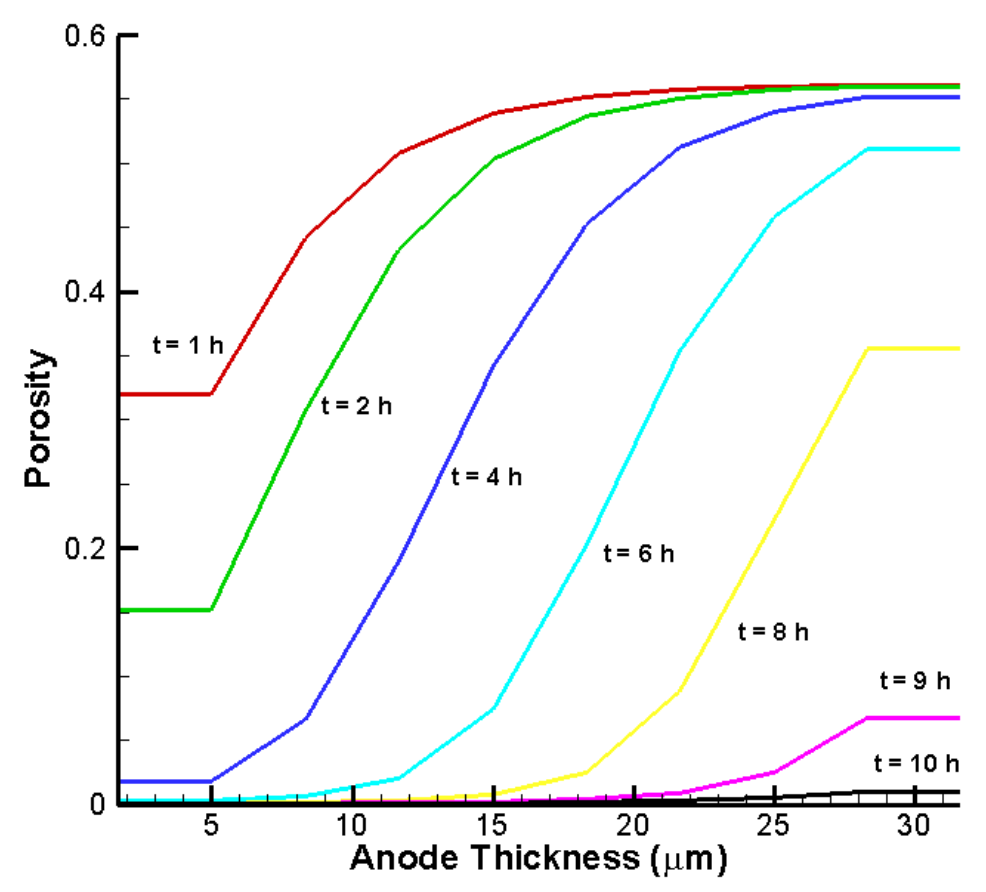

Figure 5. 11: Porosity profile at different times

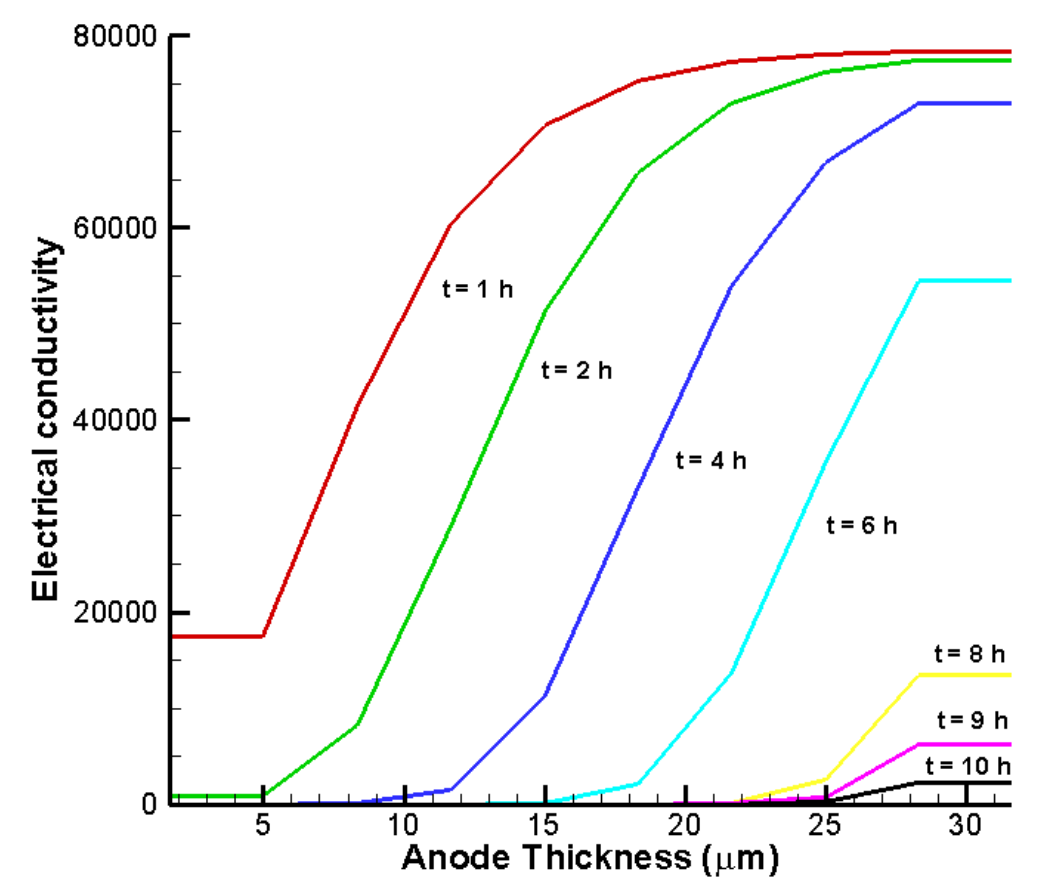

Figure 5. 12: Electrical conductivity profile at different times 


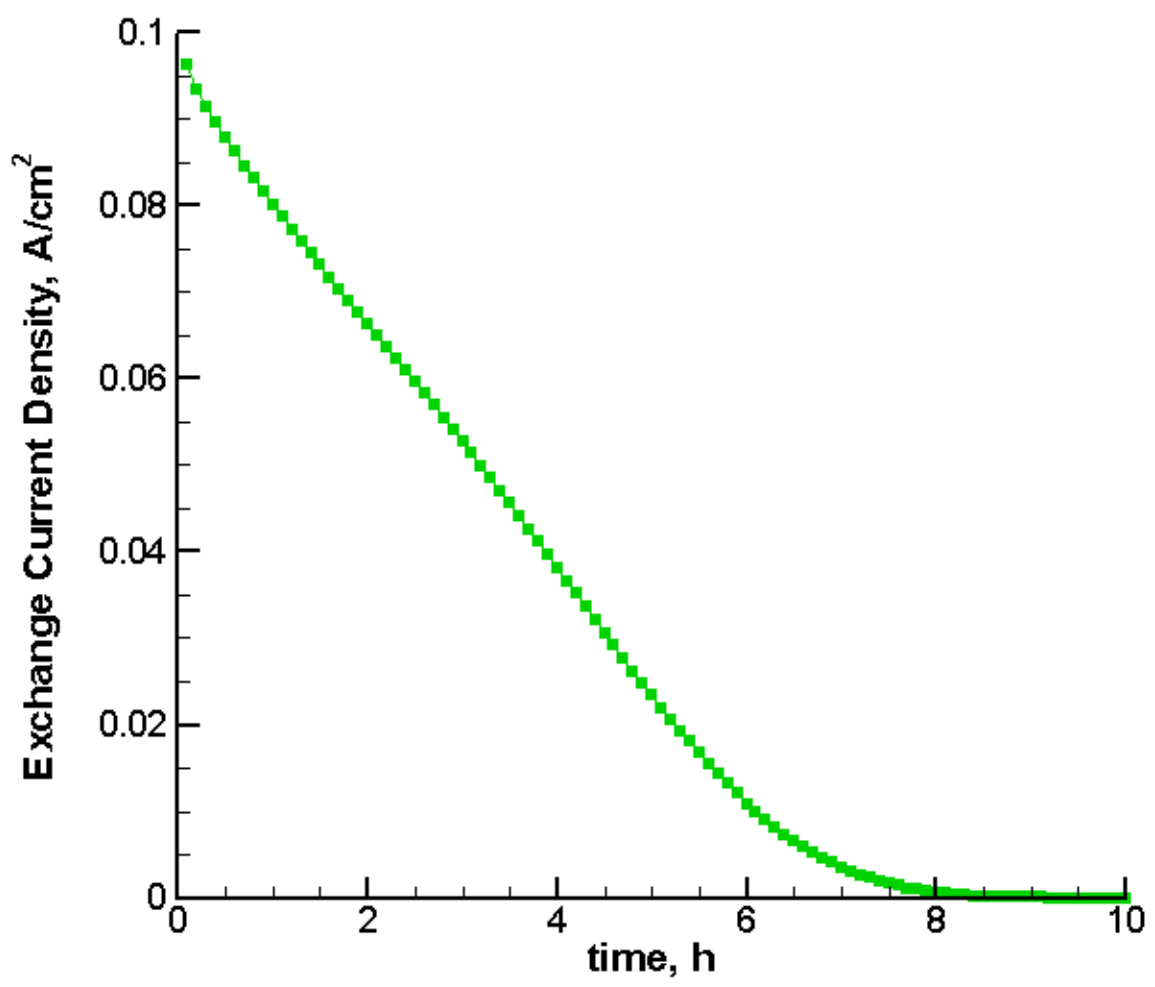

Figure 5. 13: Time evolution of the exchange current density for $\mathrm{AsH}_{3}$ impurity

Before further progression, the assumption of neglecting the losses from the cathode side is justified by including them into the simulations and comparing the results from including and omitting cathode losses. The details of cathodic overpotential calculations are given in Appendix B. The comparison results obtained for $10 \mathrm{ppm} \mathrm{AsH}_{3}$ at $800{ }^{\circ} \mathrm{C}$ are given in Figure 5.14. As can be seen from the figure, although there is slight difference in the modified power density predictions, the error is so small that the cathode losses can be safely omitted from the calculations. 


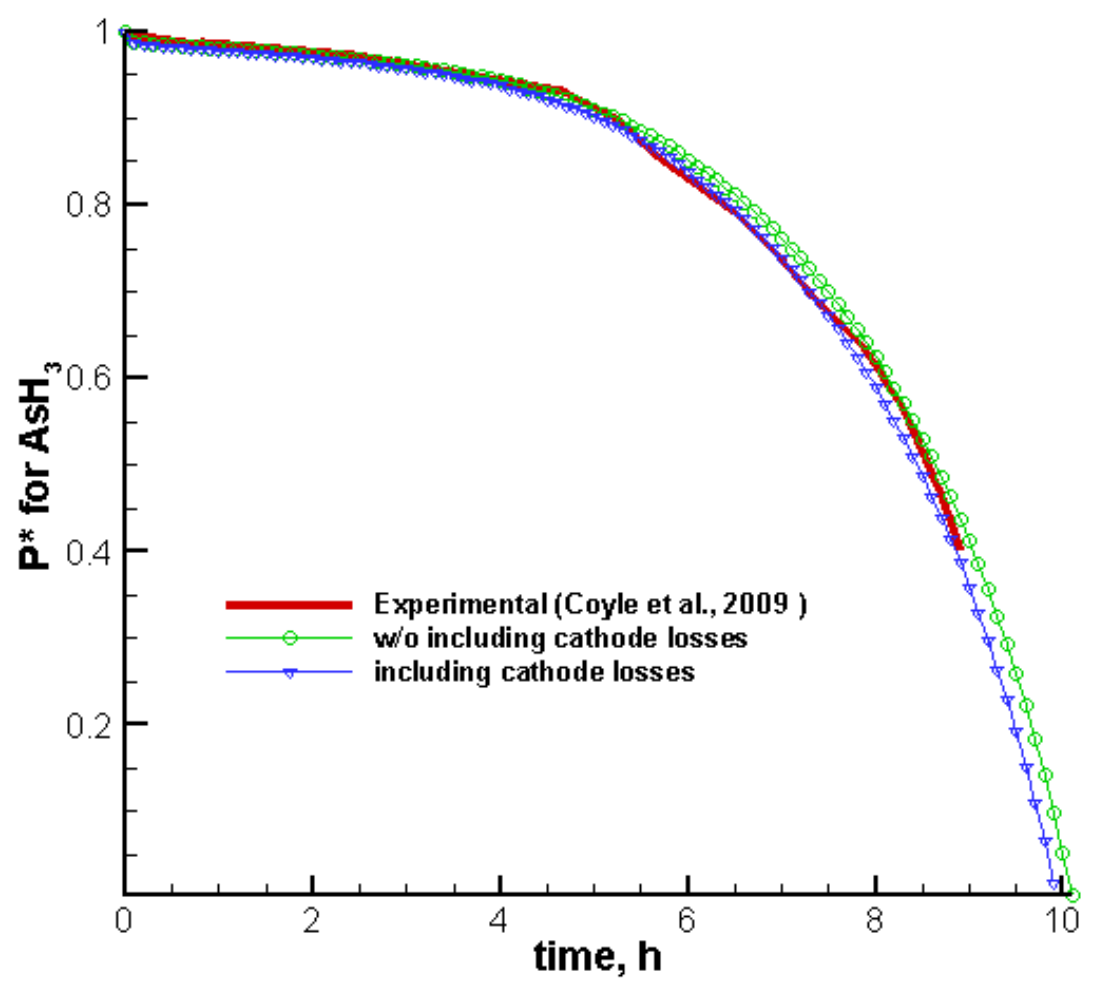

Figure 5. 14: Effect of including cathode losses to performance degradation calculations for $10 \mathrm{ppm} \mathrm{AsH}_{3}$ at $800{ }^{\circ} \mathrm{C}$

For better visualization of the front moving toward the active interface, the penetration thicknesses calculated from the model predictions were mapped onto a 2D plane representing the anode (Figure 5.15). As can be seen from the figure, the penetration thicknesses increase with increasing impurity concentration at a given time as well as increasing with time for a given concentration. This progression of the sharp interface with increasing contaminant concentration is strikingly similar to experimental observation as depicted in Figure 5.1.

The calibrated model is then validated using a different set of experimental data to test the ability of the model to predict the effects of impurity concentration and the operating temperature. Figures 5.16 a \& b display the predicted results for concentration and temperature effects, respectively. It is seen from the figures that the calibrated model 
successfully predicts the performance degradation at different contaminant concentrations and operating temperatures. It can also be seen from the figures that, although the error for $\mathrm{P}^{*}$ can be as high as $30 \%$, the cell failure time, which is the primary concern of this study, can be predicted with $4 \mathrm{~h}$ of difference.
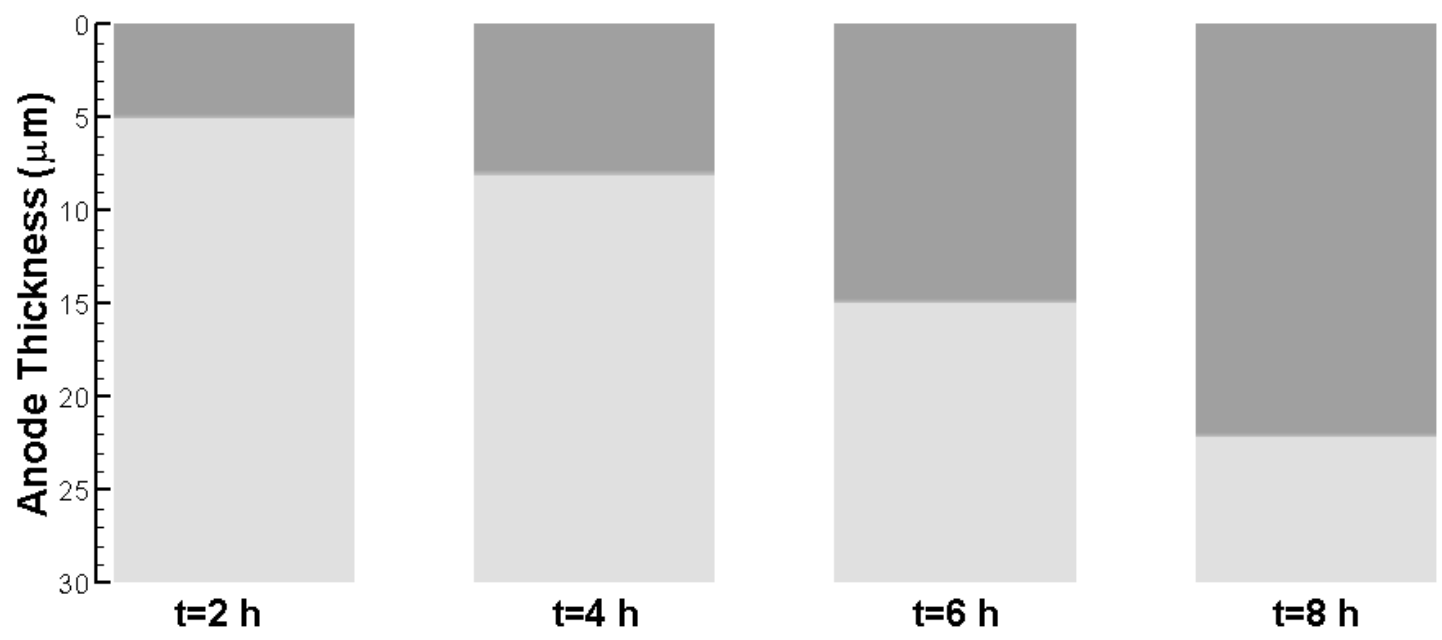

(a)
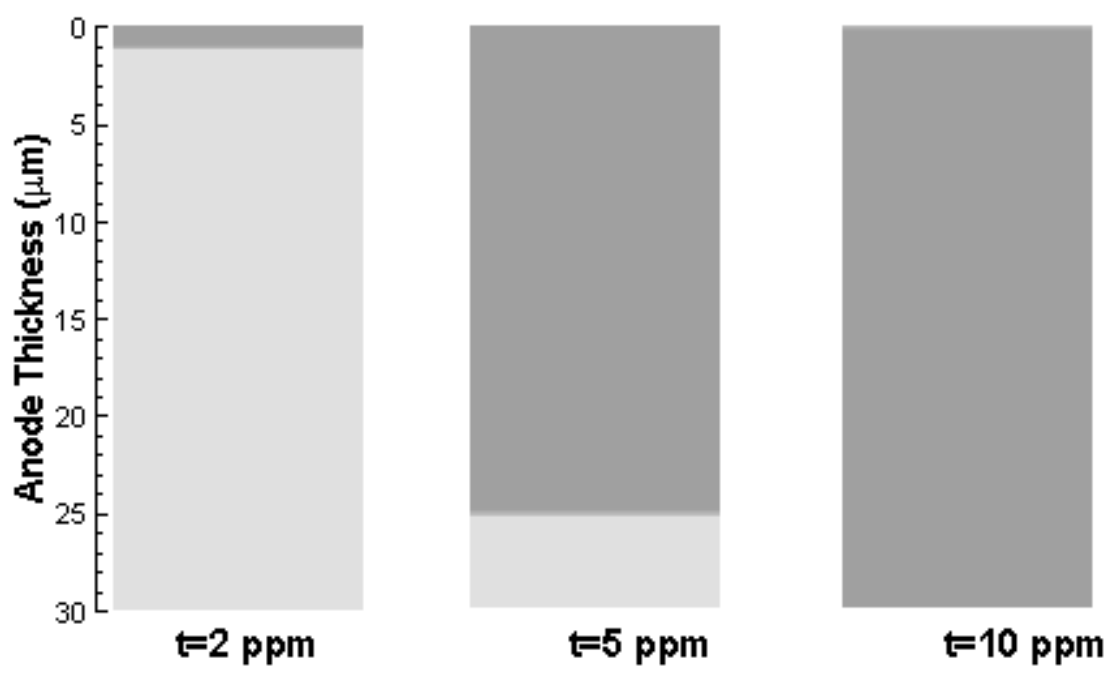

(b)

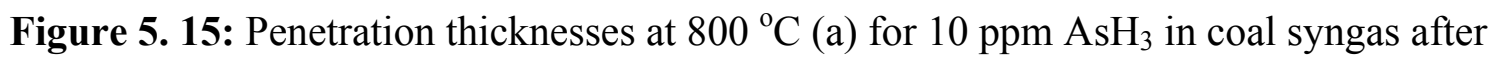
$2 \mathrm{~h}, 4 \mathrm{~h}, 6 \mathrm{~h}$ and $8 \mathrm{~h}$ of operation (b) after $10 \mathrm{~h}$ with 1,5 and $10 \mathrm{ppm} \mathrm{AsH}_{3}$ in coal syngas 


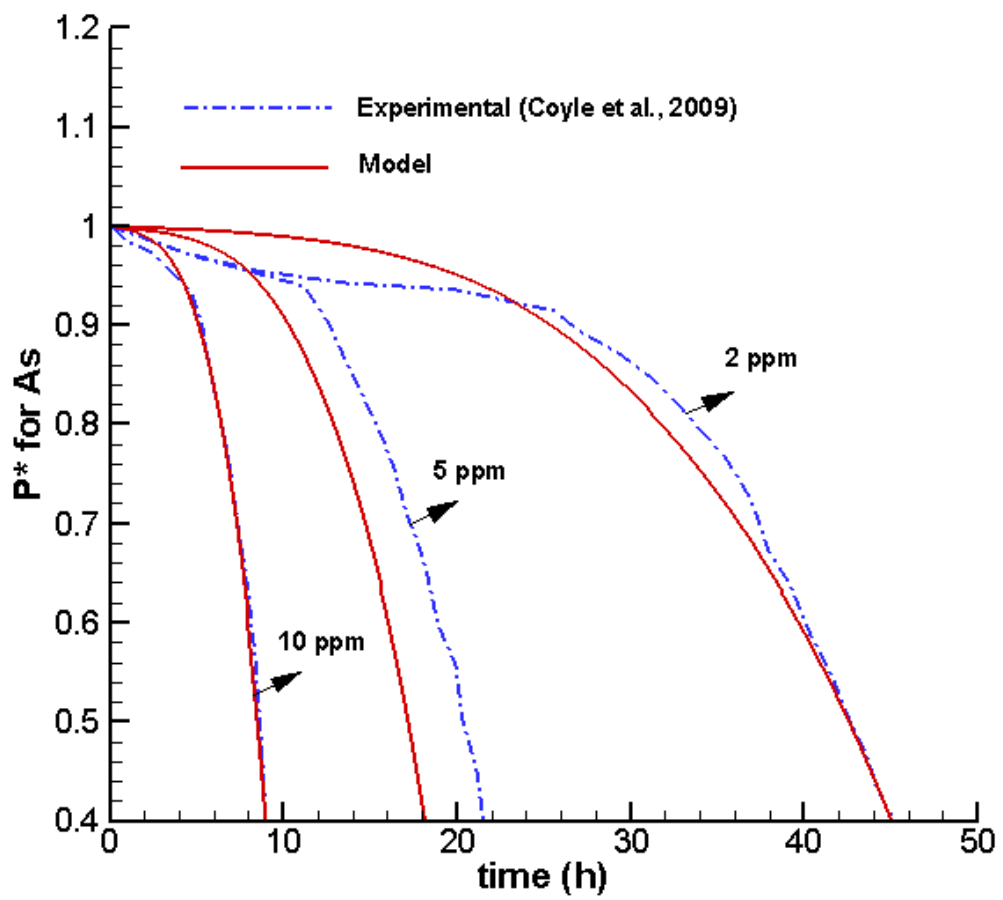

(a)

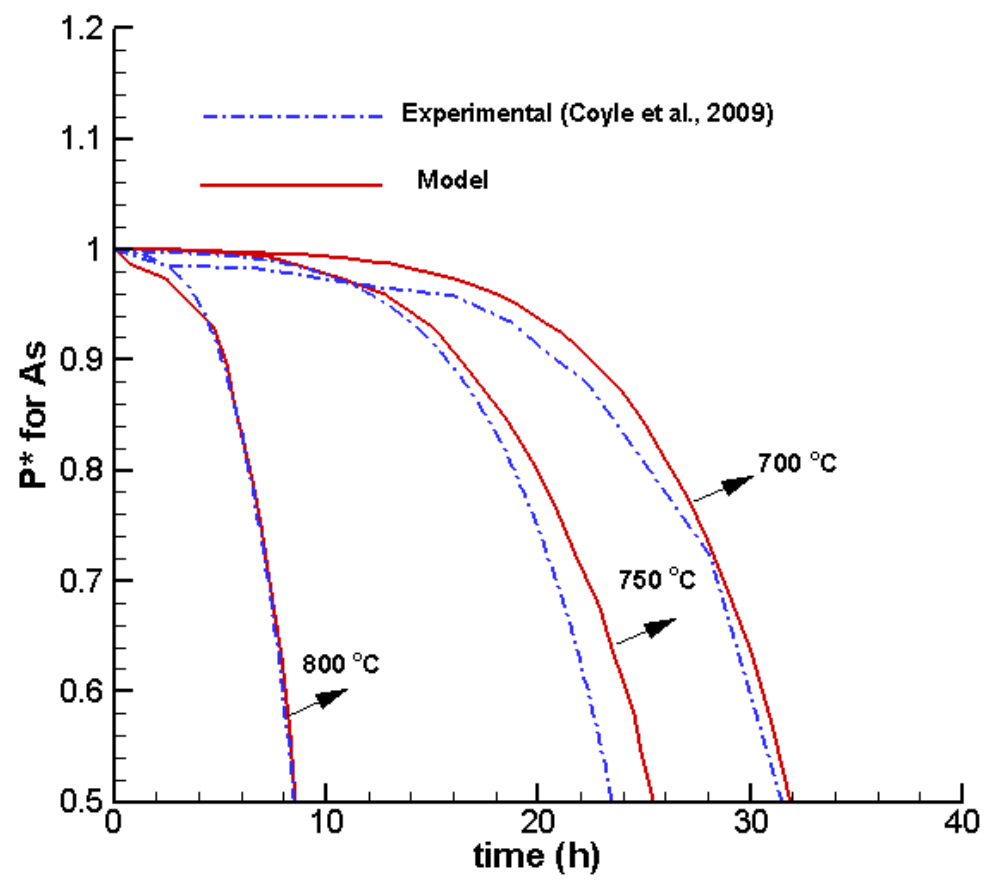

(b)

Figure 5. 16: Validation of the calibrated arsine degradation model for (a) concentration effect (b) temperature effect 
It is worth noting that all the simulations were performed at a constant current to ensure the identical conditions with the experimental data used for comparison purposes. In an attempt to identify the difference brought about by keeping the voltage constant, a

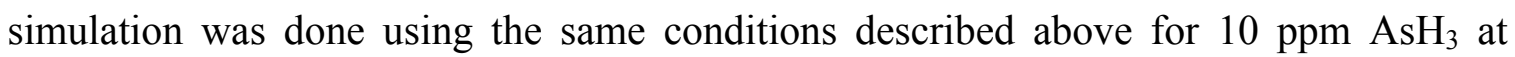
$800{ }^{\circ} \mathrm{C}$ at a constant voltage of $0.7 \mathrm{~V}$. The boundary condition at the anode/electrolyte interface was adjusted such that the molar fluxes at that interface change proportional to the changing cell current. Figure 5.17 displays the comparison between the modified power density predictions obtained from the two approaches: keeping the cell current constant at $0.05 \mathrm{~A} / \mathrm{cm}^{2}$ and keeping the voltage constant at $0.7 \mathrm{~V}$. As can be seen from the figure, the two approaches start to differ towards the cell failure time.

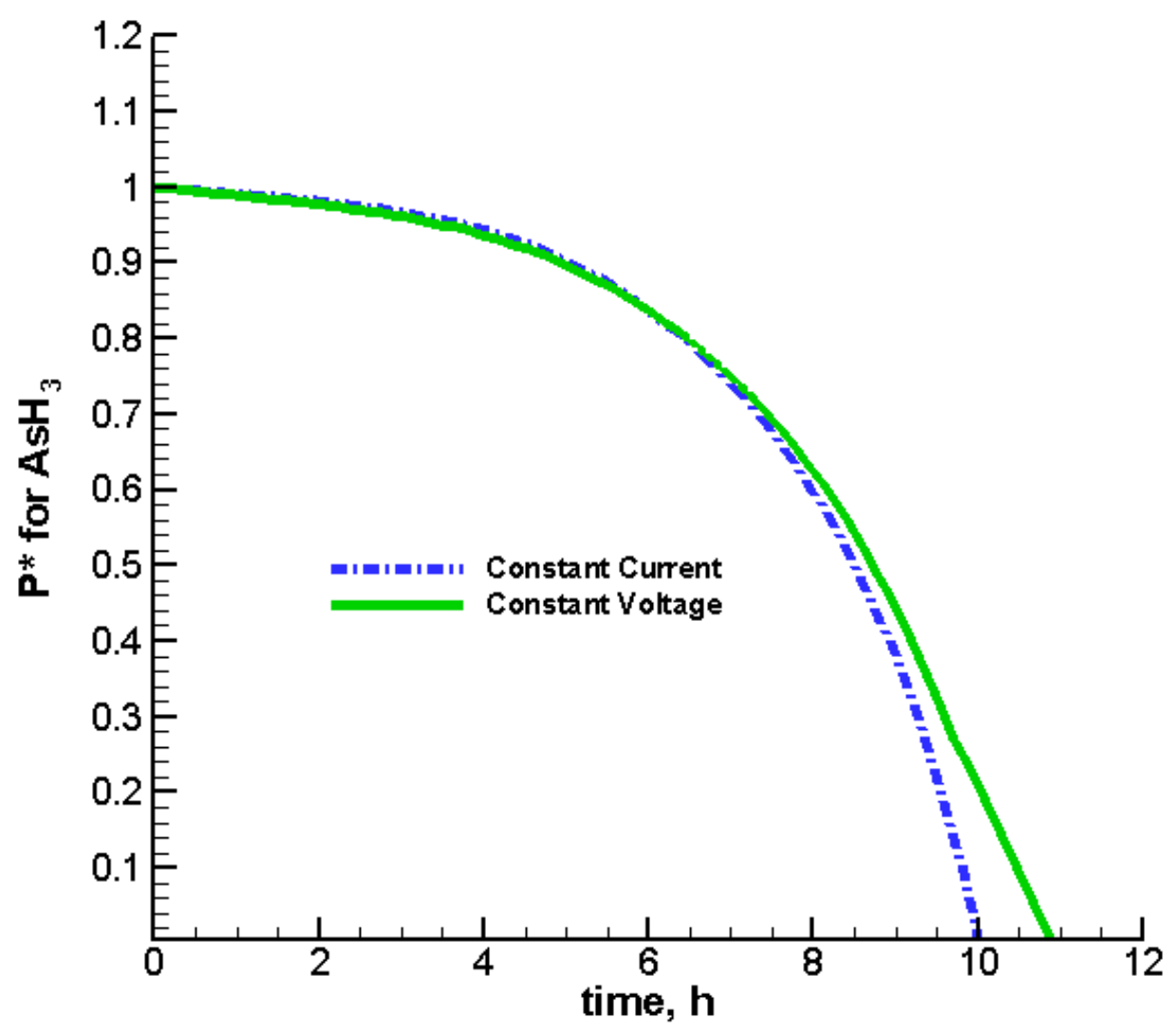

Figure 5. 17: Comparison between the modified power density predictions obtained by keeping the current constant at $0.05 \mathrm{~A} / \mathrm{cm}^{2}$ and keeping the current constant at $0.7 \mathrm{~V}$ 


\subsubsection{Phosphine}

A similar calibrating procedure was employed for $\mathrm{PH}_{3}$ impurity. The comparison is done

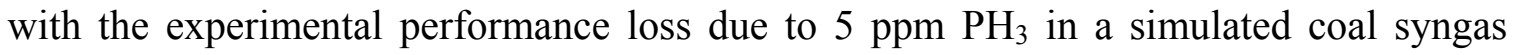
containing $23 \% \mathrm{CO}, 30 \% \mathrm{H}_{2}, 21 \% \mathrm{CO}_{2}$ and $26 \% \mathrm{H}_{2} \mathrm{O}$ at $800^{\circ} \mathrm{C}$ with a constant current density of $0.1 \mathrm{~A} / \mathrm{cm}^{2}[23]$ and the result is given in Figure 5.18.

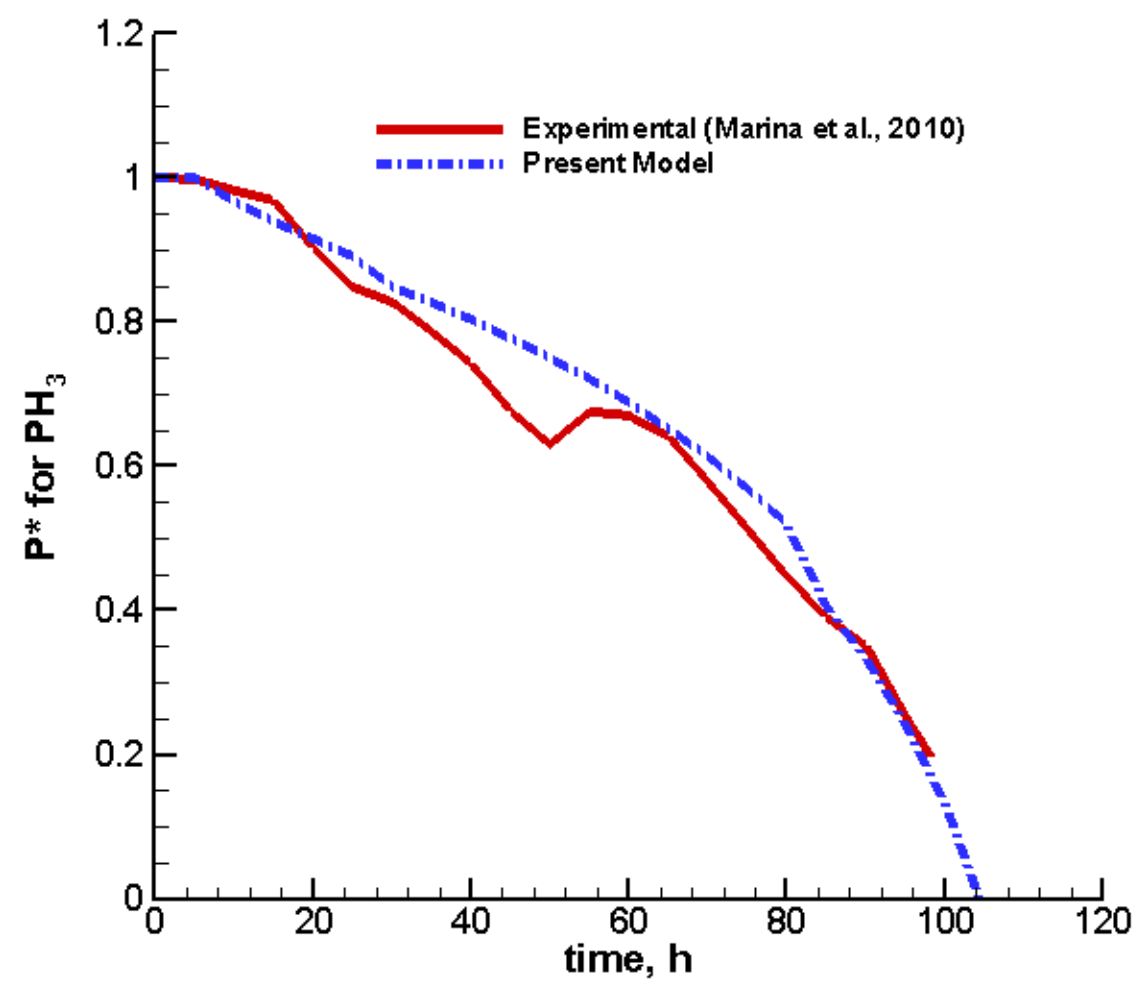

Figure 5. 18: Calibration of modified power density against experimental data adopted

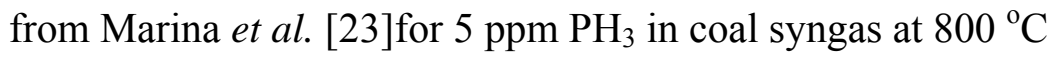

In this case as well it was possible to achieve a fairly good agreement between the modified power density profiles obtained from the proposed model and the experimental data from literature. The calibrated parameters are given in Table 5.3. 
Table 5. 3: Calibrated parameters for $\mathrm{PH}_{3}$ impurity

\begin{tabular}{|l|l|}
\hline \multicolumn{1}{|c|}{ Parameter } & \multicolumn{1}{c|}{ Value } \\
\hline$k_{f, X}, \mathrm{~s}^{-1}$ & $5.0 \times 10^{2}$ \\
\hline$k_{b, X}, \mathrm{~s}^{-1}$ & $9.1 \times 10^{-3} \exp \left(-9.23 \times 10^{4} / \mathrm{RT}\right)$ \\
\hline$m$ & 0.01 \\
\hline$n$ & 2.2 \\
\hline$p$ & 2.0 \\
\hline$q$ & 2.0 \\
\hline
\end{tabular}

It should be noted that the forward reaction rate constant for contaminant coverage is not a function of temperature. The reason for this is that experimental data available for electrolyte-supported cells [23] showed no clear dependence on temperature as opposed to other experiments performed on anode-supported cells [79].

The interface coverage as a function of time is given in Figure 5.19. It is evident from the comparisons of the Figures 5.18 and 5.19 that, once the contaminant coverage reaches a certain limit at the active interface, the cell fails immediately without experiencing the typical final slow degradation stage. 


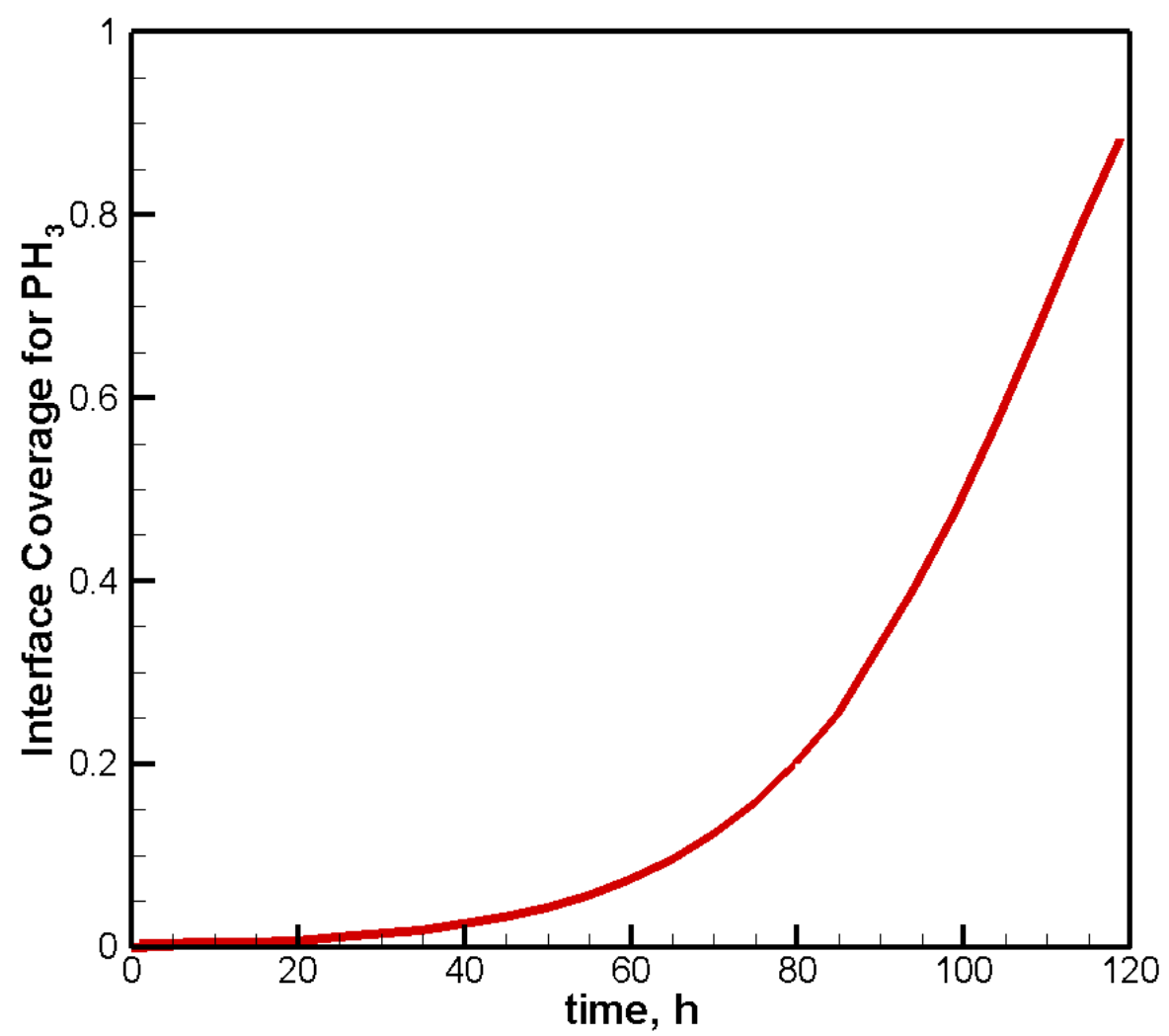

Figure 5. 19: Time evolution of the interface coverage for $\mathrm{PH}_{3}$ impurity

The validation of the calibrated model was done against the experimental data to test the ability of the calibrated model to predict the effects of impurity concentration and the operating temperature. The comparison between the modified power density results obtained from the current model and those of the experiments for different impurity concentrations is shown in Figure 5.20. It is clearly seen from the figure that the model closely emulates the typical degradation patterns observed at different impurity concentrations. 


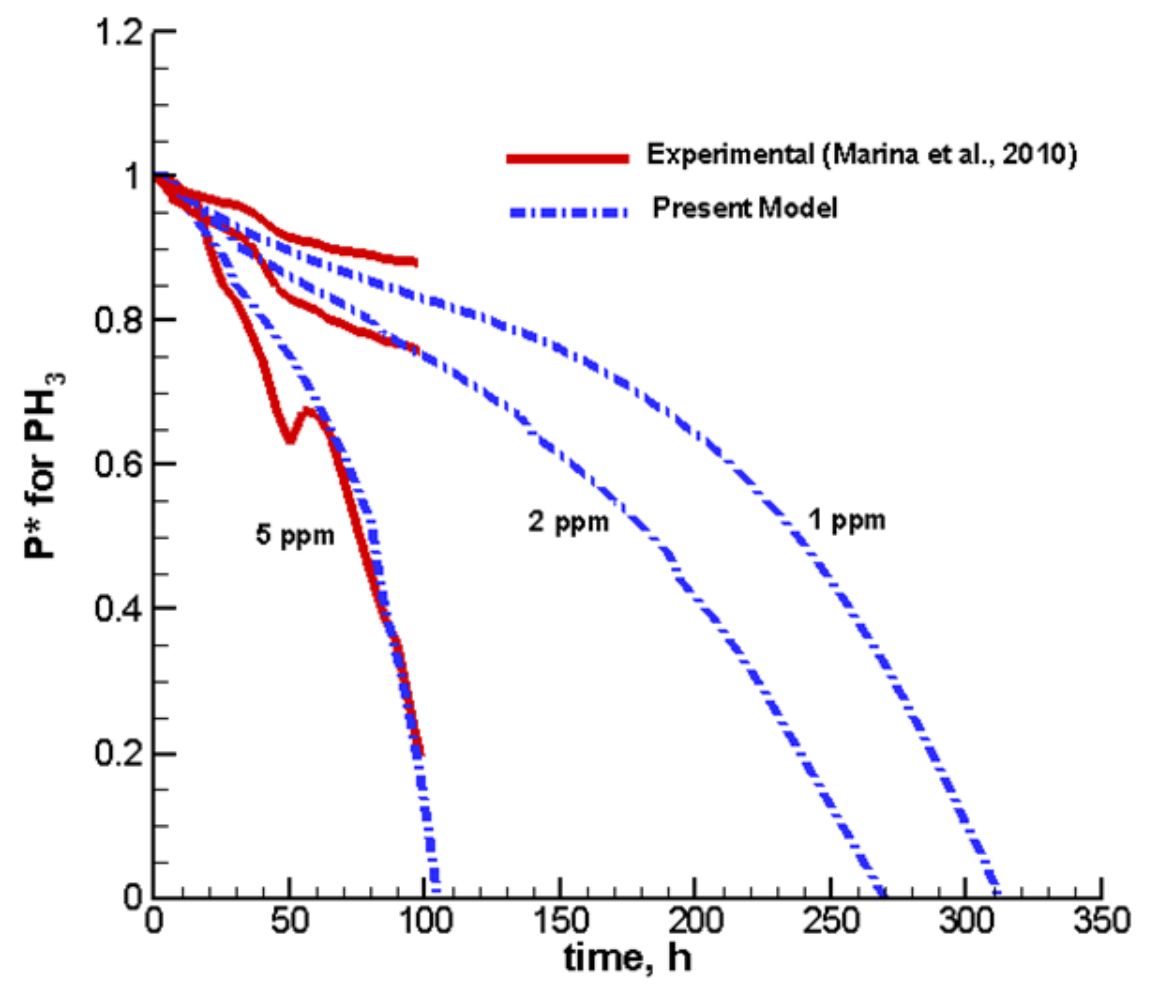

Figure 5. 20: Validation of the calibrated phosphine degradation model for concentration effect

\subsubsection{Hydrogen Sulfide}

Figure 5.21 and 5.22 show the calibrated model results for the performance degradation due to $20 \mathrm{ppm}_{2} \mathrm{~S}$ in wet $\mathrm{H}_{2}$ gas $\left(95 \% \mathrm{H}_{2} / 5 \% \mathrm{H}_{2} \mathrm{O}\right)$ and the corresponding interface coverage for the impurity, respectively. The calibration was done using experimental data of $\mathrm{Xu}$ [84] performed at $800{ }^{\circ} \mathrm{C}$ and a constant current density of $0.2 \mathrm{~A} / \mathrm{cm}^{2}$ and the calibrated parameters are given in Table 5.4.

Figures 5.21 and 5.22 reveal that the degradation occurs in four stages: an initial loss of activity followed by a plateau and then a period of more rapid power loss and finally a very slow degradation. As shown in Figure 5.21 the model results closely follows the experimental data except that experimental performance curve stabilizes at a higher power than the model results. Although there is a $50 \%$ difference between the predicted 
results and the experimental data in that region, the results are still encouraging given the simplicity of the model.

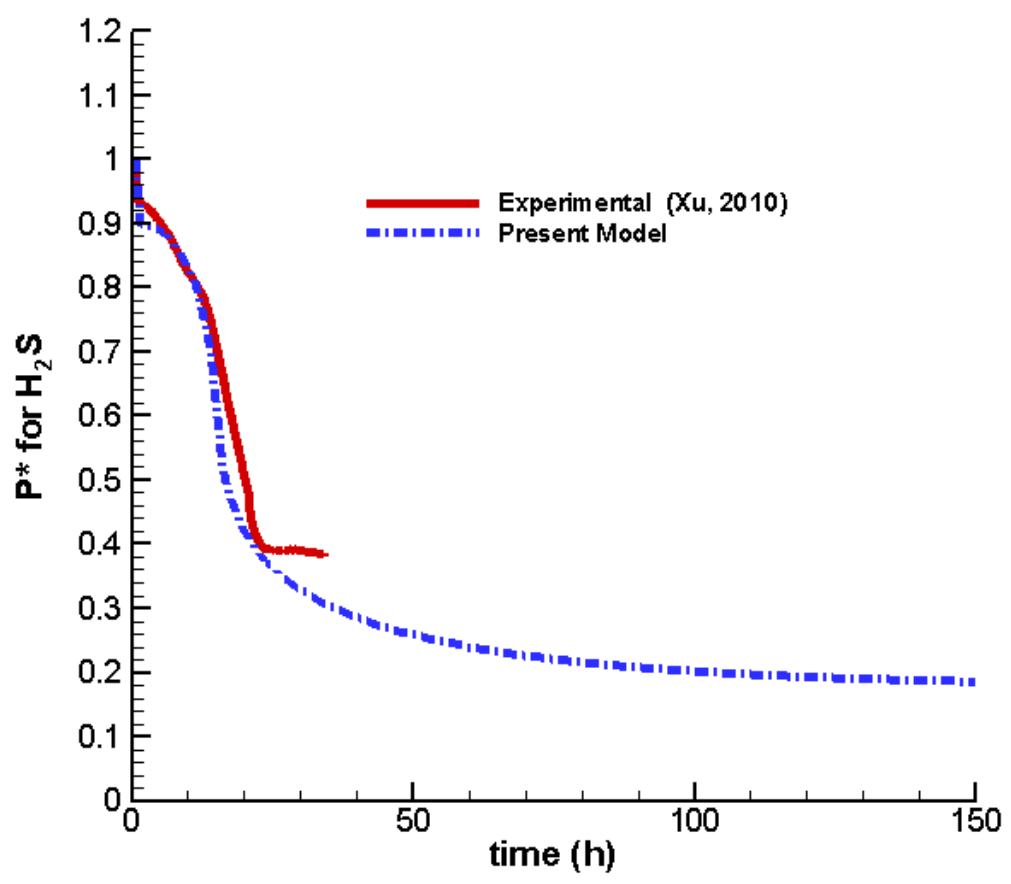

Figure 5. 21: Calibration of modified power density against experimental data adopted from $\mathrm{Xu}$ [84] for $20 \mathrm{ppm} \mathrm{H}_{2} \mathrm{~S}$ in wet $\mathrm{H}_{2}$ at $800{ }^{\circ} \mathrm{C}$

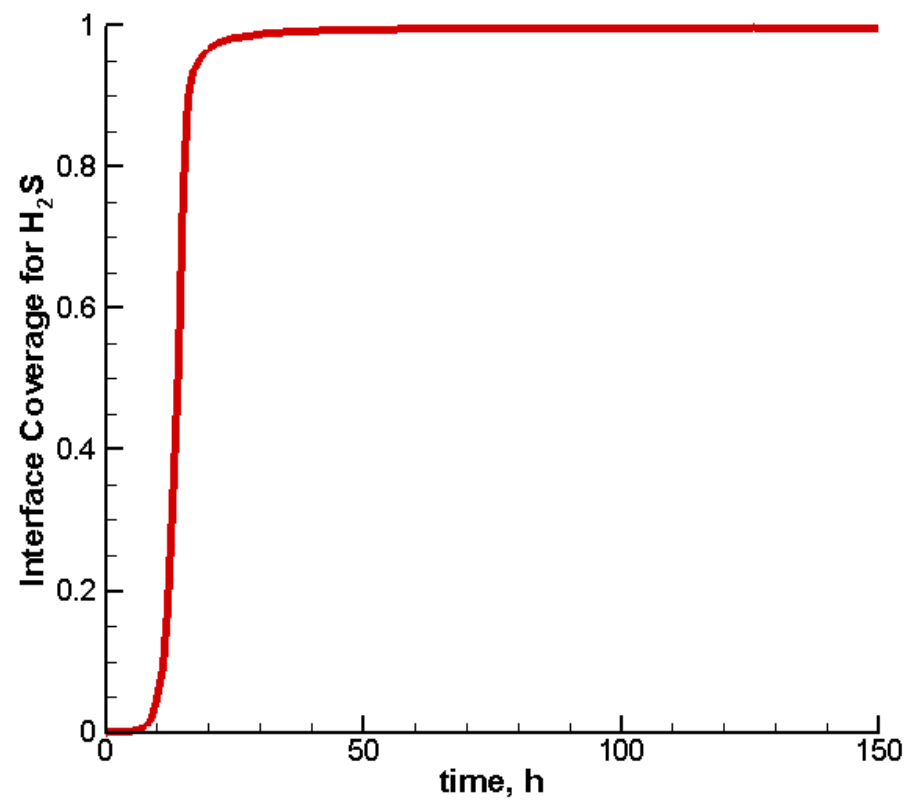

Figure 5. 22: Time evolution of the interface coverage for $\mathrm{H}_{2} \mathrm{~S}$ impurity 
Table 5. 4: Calibrated parameters for $\mathrm{H}_{2} \mathrm{~S}$ impurity

\begin{tabular}{|l|l|}
\hline \multicolumn{1}{|c|}{ Parameter } & \multicolumn{1}{c|}{ Value } \\
\hline$k_{f, X}, \mathrm{~s}^{-1}$ & $1.0 \times 10^{3}$ \\
\hline$k_{b, X}, \mathrm{~s}^{-1}$ & $1.8 \times 10^{-2} \exp \left(-9.28 \times 10^{4} / \mathrm{RT}\right)$ \\
\hline$m$ & 0.04 \\
\hline$n$ & 1.2 \\
\hline$p$ & 3.0 \\
\hline$q$ & 3.0 \\
\hline
\end{tabular}

\subsubsection{Hydrogen Selenide}

Calibration for $1.5 \mathrm{ppm}_{2} \mathrm{Se}$ in a simulated coal syngas containing $23 \% \mathrm{CO}, 30 \% \mathrm{H}_{2}$, $21 \% \mathrm{CO}_{2}$ and $26 \% \mathrm{H}_{2} \mathrm{O}$ was also done against the experiments conducted at $700^{\circ} \mathrm{C}$ with a constant current density of $0.25 \mathrm{~A} / \mathrm{cm}^{2}$ [21]. Calibration result is given in Figure 5.23 along with the validation of the calibrated data for a different concentration.

As can be seen from Figure 5.23, model can successfully predict the performance degradation curve. The calibrated parameters are given in Table 5.5. 
Table 5. 5: Calibrated parameters for $\mathrm{H}_{2} \mathrm{Se}$ impurity

\begin{tabular}{|l|l|}
\hline \multicolumn{1}{|c|}{ Parameter } & \multicolumn{1}{c|}{ Value } \\
\hline$k_{f, X}, \mathrm{~s}^{-1}$ & $2.0 \times 10^{3}$ \\
\hline$k_{b, X}, \mathrm{~s}^{-1}$ & $9.1 \times 10^{-2} \exp \left(-9.25 \times 10^{4} / \mathrm{RT}\right)$ \\
\hline$m$ & 0.02 \\
\hline$n$ & 1.4 \\
\hline$p$ & 2.0 \\
\hline$q$ & 2.0 \\
\hline
\end{tabular}

The interface coverage as a function of time given in Figure 5.24 shows that, the trend is similar to that of $\mathrm{H}_{2} \mathrm{~S}$ where the performance stabilizes in the final phase of the degradation.

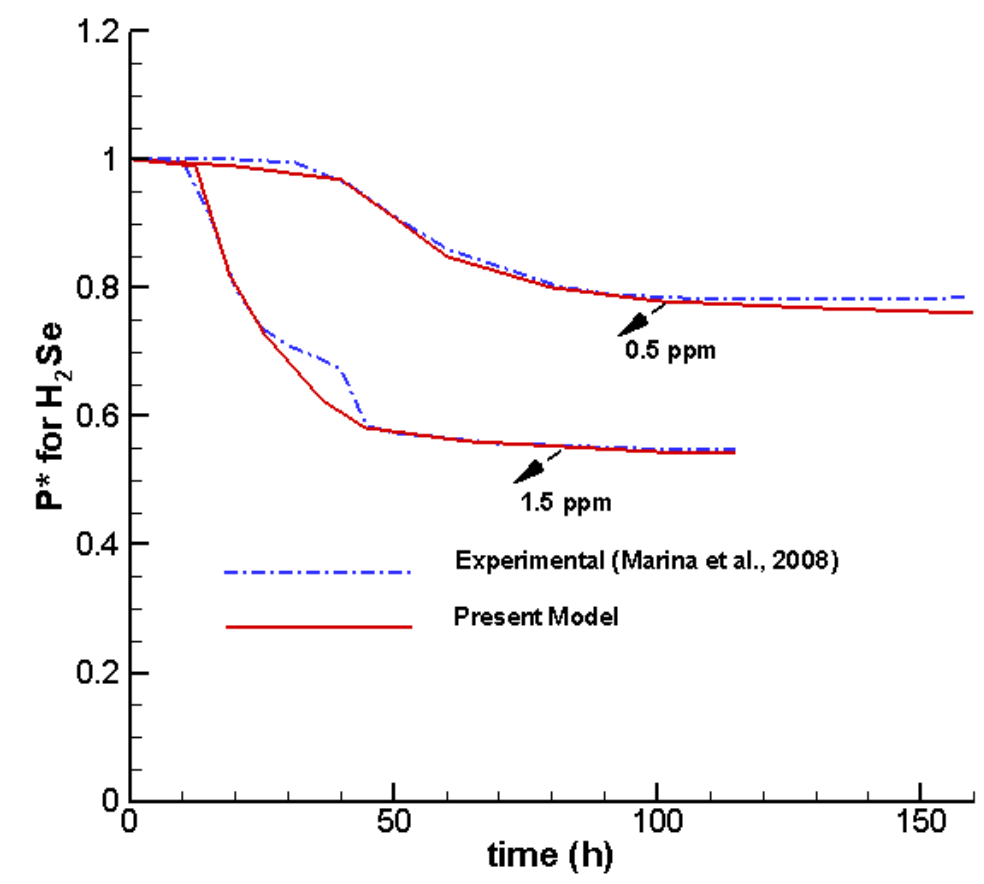

Figure 5. 23: Calibration of modified power density against experimental data adopted from Marina et al. [21] for $1.5 \mathrm{ppm} \mathrm{H}_{2} \mathrm{Se}$ in coal syngas at $800{ }^{\circ} \mathrm{C}$ 


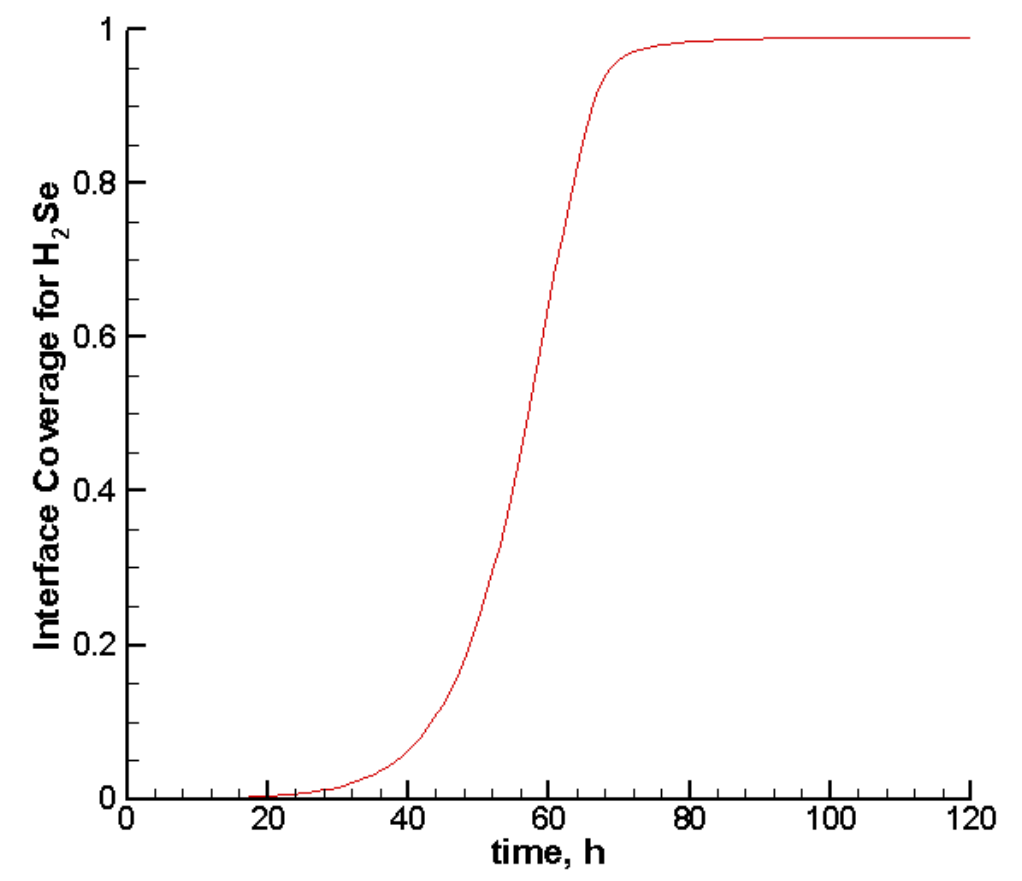

Figure 5. 24: Time evolution of the interface coverage for $1.5 \mathrm{ppm}_{2} \mathrm{Se}$ impurity

\subsection{Multi-Component Impurity}

In order to account for the effect of each additional contaminant, $Y$, in a system of multiple impurities, an additional adsorption reaction is included in the model along with the mechanism given in Eq.s (5.2) and (5.3):

$Y+N i \stackrel{k_{f, Y}}{\underset{k_{b, Y}}{\rightleftharpoons}} N i-Y$

Also, Eq. (5.4) has to be solved for each additional impurity. Once the coverage profiles are obtained for the impurities in the mixture, several averaging approaches were tested for calculation of the exchange current density as a function of interface impurity coverages. First approach is the simple multiplication of the contributions from each contaminant: 
$i_{o, H_{2}}=i_{o, r e f}\left(1-\theta_{N i-X, \text { int }}^{m}\right)^{n}\left(1-\theta_{N i-Y, \text { int }}^{k}\right)^{l}$

where $\theta_{N i-X, \text { int }}$ and $\theta_{N i-Y, \text { int }}$ are the interface coverages for the impurity species $X$ and $Y$, respectively. $i_{o, r e f}$ is the reference exchange current density at zero percent coverage given by

$i_{o, \text { ref }}=c_{1}\left(\frac{y_{H_{2}, \text { int }}}{y_{H_{2}, \text { ref }}}\right) \exp \left(-\frac{E_{a c t, H_{2}}}{R_{u} T}\right)$

Second approach evaluated is based on taking the weighted averages of the contaminant coverages at the active interface and is represented by the following closed form relation:

$i_{o, H_{2}}=i_{o, r e f}\left[\frac{\left(1-\theta_{\mathrm{int}, N i-X}^{m}\right)^{n} \theta_{\mathrm{int}, N i-X}+\left(1-\theta_{\mathrm{int}, N i-Y}^{k}\right)^{l} \theta_{\mathrm{int}, N i-Y}}{\theta_{\mathrm{int}, N i-X}+\theta_{\mathrm{int}, N i-Y}}\right]$

In the third approach, the exchange current density is assumed to be a function of harmonic averages of the interface coverages of the impurities:

$i_{o, H_{2}}=i_{o, r e f}\left[\frac{\left(\theta_{\mathrm{int}, N i-X}+\theta_{\mathrm{int,Ni-Y}}\right)\left(1-\theta_{\mathrm{int,Ni-X}}^{m}\right)^{n}\left(1-\theta_{\mathrm{int}, N i-Y}^{k}\right)^{l}}{\theta_{\mathrm{int}, N i-X}\left(1-\theta_{\mathrm{int}, N i-Y}^{k}\right)^{l}+\theta_{\mathrm{int}, N i-Y}\left(1-\theta_{\mathrm{int}, N i-X}^{m}\right)^{n}}\right]$

Another approach is to use the weighted average of the powers. As the name implies, the interface coverage dependence of the exchange current density is represented by the weighted averages of the powers, $m, n, k$ and $l$ and given by the following equations: 


$$
\begin{aligned}
& m^{*}=\frac{m \theta_{\mathrm{int}, N i-X}+k \theta_{\mathrm{int,Ni-Y}}}{\theta_{\mathrm{int}, N i-X}+\theta_{\mathrm{int}, N i-Y}} \\
& n^{*}=\frac{n \theta_{\mathrm{int}, N i-X}+l \theta_{\mathrm{int}, N i-Y}}{\theta_{\mathrm{int}, N i-X}+\theta_{\mathrm{int}, N i-Y}} \\
& \theta_{\mathrm{int}}^{*}=\theta_{\mathrm{int}, N i-X}+\theta_{\mathrm{int}, N i-Y} \\
& i_{o, H_{2}}=i_{o, r e f}\left(1-\left(\theta_{\mathrm{int}}^{*}\right)^{m^{*}}\right)^{n^{*}}
\end{aligned}
$$

In what follows, the approaches explained above were applied to multi-component impurity cases including $\mathrm{AsH}_{3}$ and $\mathrm{PH}_{3} ; \mathrm{AsH}_{3}$ and $\mathrm{H}_{2} \mathrm{~S} ; \mathrm{PH}_{3}$ and $\mathrm{H}_{2} \mathrm{~S} ; \mathrm{AsH}_{3}, \mathrm{PH}_{3}$ and $\mathrm{H}_{2} \mathrm{~S}$. The model predictions were not compared to any experimental data since there are only a few studies in the literature considering the synergistic effects of the coal syngas impurities and these experiments are performed on anode-supported cells $[17,81]$.

All the simulations are performed for an electrolyte supported cell with an anode thickness of $30 \mu \mathrm{m}$ and at a typical SOFC operating temperature of $800{ }^{\circ} \mathrm{C}$. Current density is kept constant at $0.1 \mathrm{~A} / \mathrm{cm}^{2}$ for all simulations. The coal syngas composition is $23 \% \mathrm{CO}, 30 \% \mathrm{H}_{2}, 21 \% \mathrm{CO}_{2}$ and $26 \% \mathrm{H}_{2} \mathrm{O}$.

\subsubsection{Arsine and Phosphine Mixture}

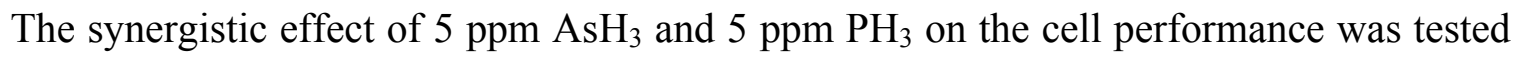
using the averaging techniques described above for effective exchange current density as a function of the interface coverages and the results are given in Figure 5.25. As can be seen from the figure, adsorption reaction kinetics for arsine is much faster than that of phosphine and thus, modified power density results from all the averaging techniques collapse down to arsine degradation curve with slightly less performance than single $\mathrm{AsH}_{3}$ impurity case. 


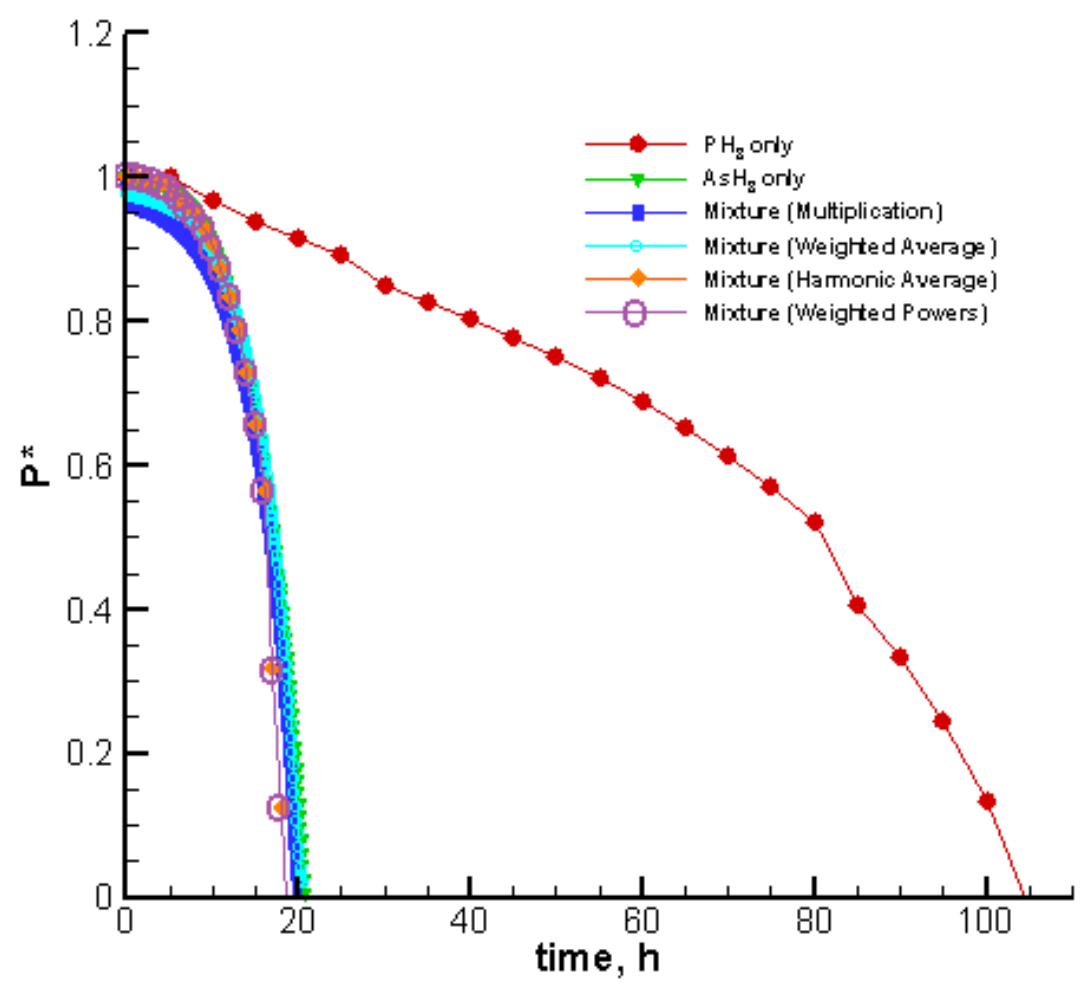

Figure 5. 25: Comparison of performance loss for a mixture of 5 ppm $\mathrm{AsH}_{3}$ and $5 \mathrm{ppm}$ $\mathrm{PH}_{3}$ with different averaging techniques

The result of fast kinetics of arsine coverage is clearly seen in Figures 5.26 and 5.27 which show the change in interface coverages with time and the concentration profiles along the thickness of the anode after 20 hours, respectively. Figure 5.26 illustrates that, the interface coverage for arsine reaches it highest value when the front of phosphine coverage just arrives at the active interface. In addition, arsine concentration reaches the prescribed free stream concentration long before phosphine impurity (see Figure 5.27). Since the apparent concentration for $\mathrm{AsH}_{3}$ inside the anode is approximately five times more than that of $\mathrm{PH}_{3}$, mixture performance curve follows the $\mathrm{AsH}_{3}$ degradation path. 


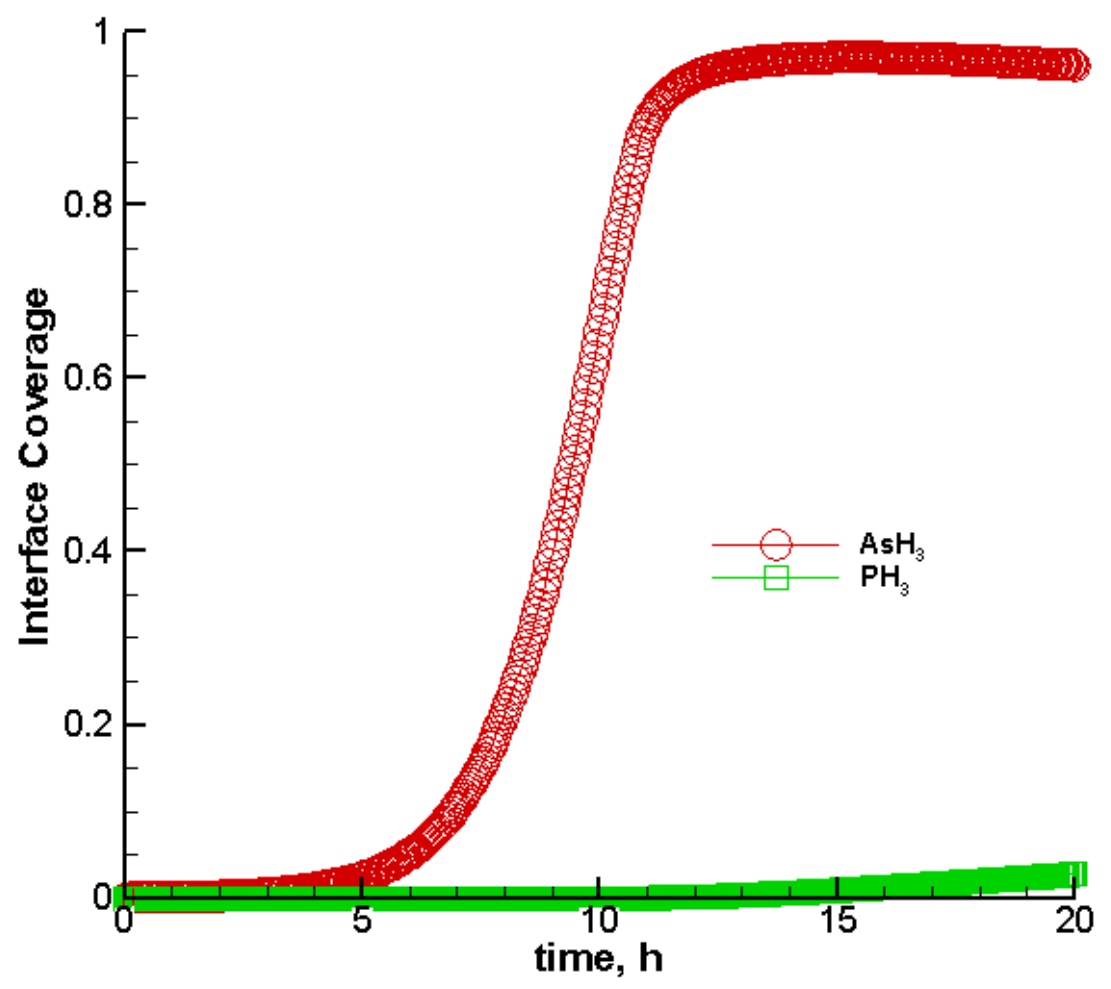

Figure 5. 26: Time evolution of interface coverages for $5 \mathrm{ppm} \mathrm{AsH}_{3}$ and $5 \mathrm{ppm}^{\mathrm{PH}}$ 


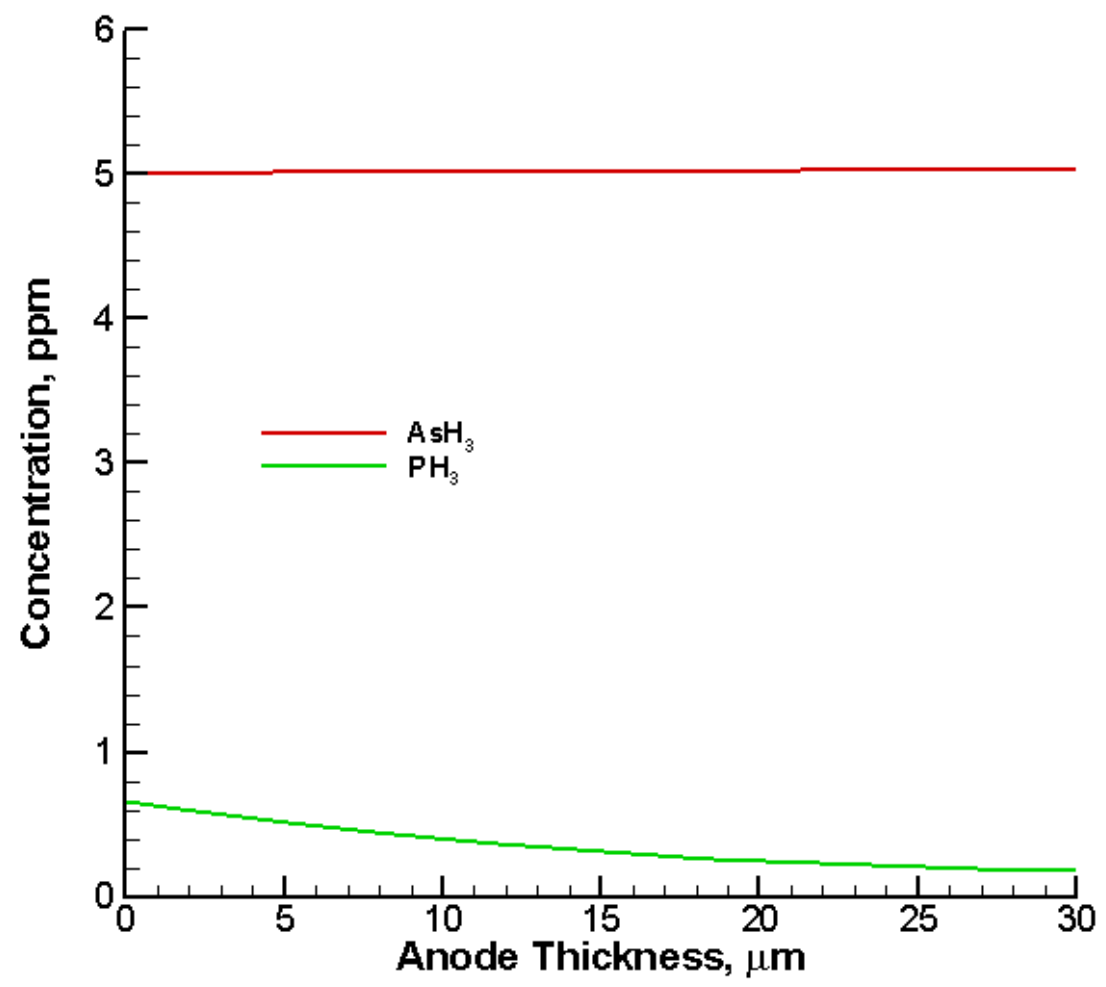

Figure 5. 27: Concentration profiles for $5 \mathrm{ppm} \mathrm{AsH}_{3}$ and $5 \mathrm{ppm} \mathrm{PH}_{3}$ along the thickness of the anode at $\mathrm{t}=20 \mathrm{~h}$

\subsubsection{Arsine and Hydrogen Sulfide Mixture}

The performance degradation due to $5 \mathrm{ppm} \mathrm{AsH}_{3}$ and $5 \mathrm{ppm}_{2} \mathrm{~S}$ was also tested and results with different averaging techniques are given in Figure 5.28. Investigation of

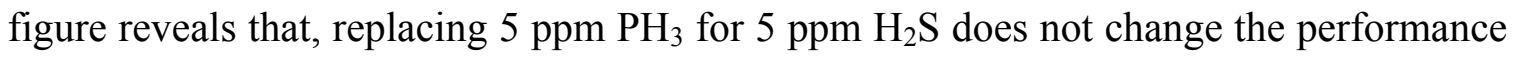
results regardless of the averaging technique used. 


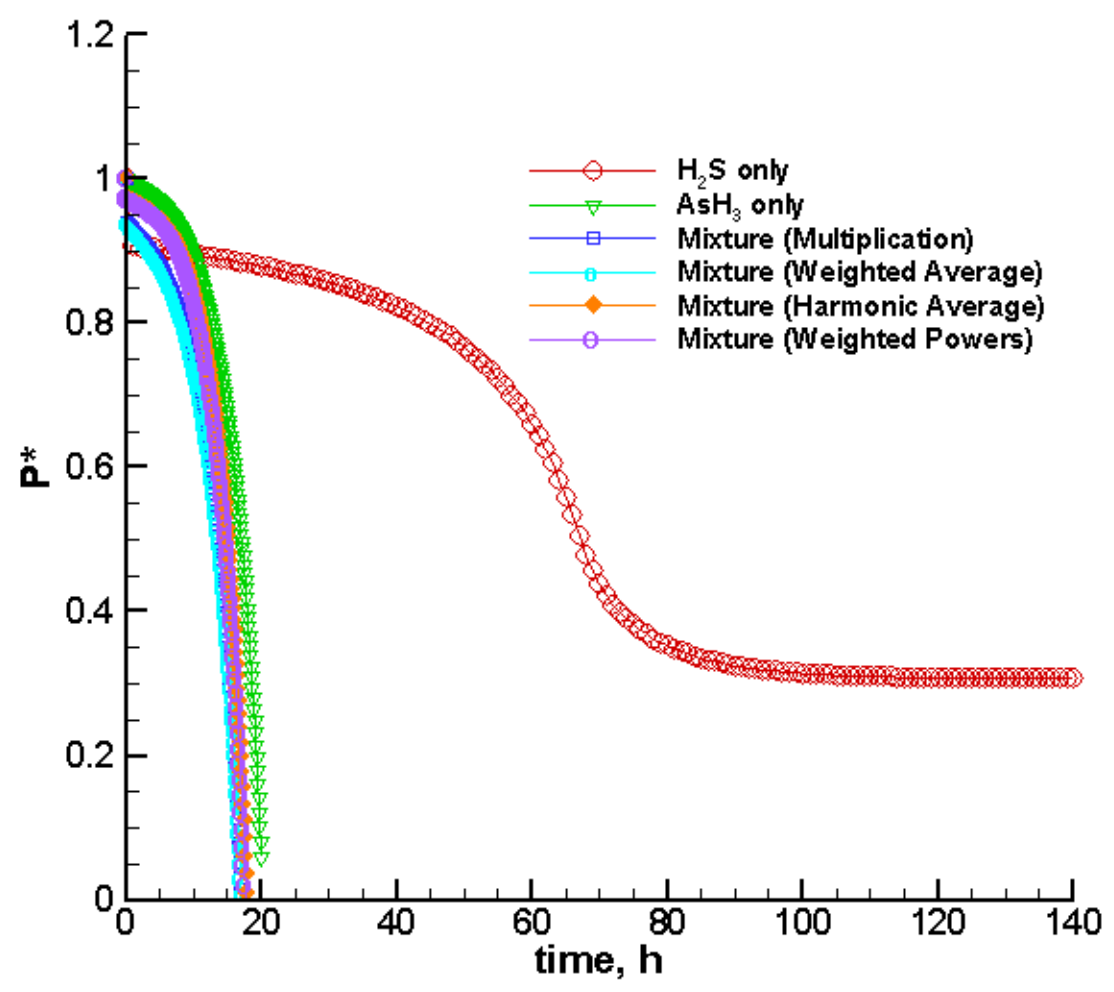

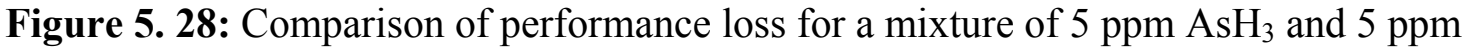
$\mathrm{H}_{2} \mathrm{~S}$ with different averaging techniques

Interface coverages as a function of time for $\mathrm{AsH}_{3}$ and $\mathrm{H}_{2} \mathrm{~S}$ impurities is given in Figure 5.29. Similar to $\mathrm{AsH}_{3}$ and $\mathrm{PH}_{3}$ mixture case, interface coverage for $\mathrm{AsH}_{3}$ is about nine times more than that of $\mathrm{H}_{2} \mathrm{~S}$ meaning all $90 \%$ of all the available catalyst sites are covered by $\mathrm{AsH}_{3}$ impurity and only $10 \%$ is covered by $\mathrm{H}_{2} \mathrm{~S}$ and $\mathrm{H}_{2}$. Moreover, it is shown in Figure 5.30 that, the concentration of $\mathrm{AsH}_{3}$ at the active interface is five times more than that of $\mathrm{H}_{2} \mathrm{~S}$. 


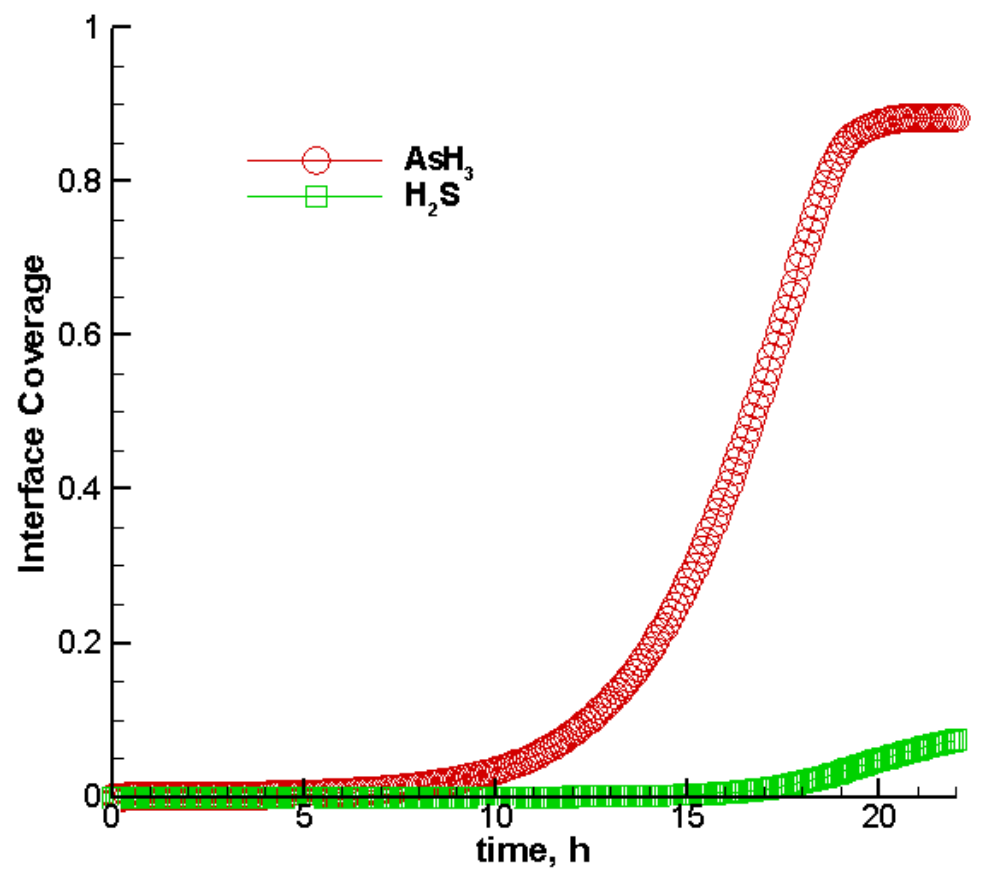

Figure 5. 29: Time evolution of interface coverages for $5 \mathrm{ppm} \mathrm{AsH}_{3}$ and $5 \mathrm{ppm}_{2} \mathrm{~S}$

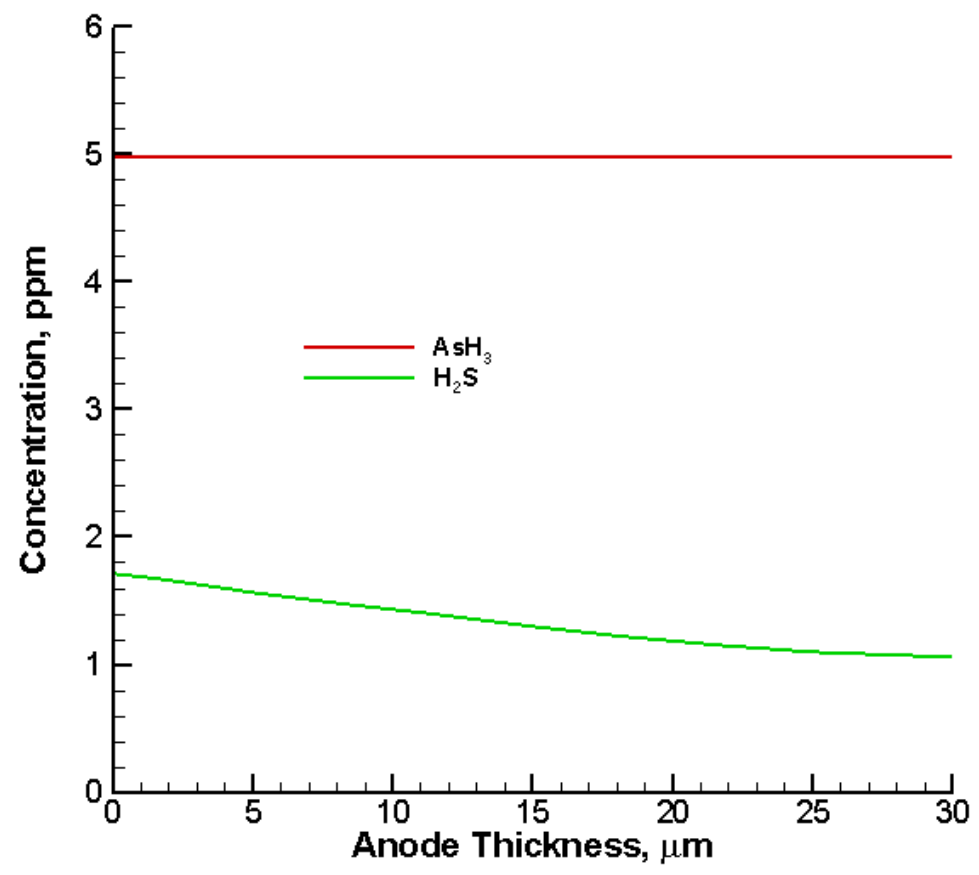

Figure 5. 30: Concentration profiles for $5 \mathrm{ppm} \mathrm{AsH}_{3}$ and $5 \mathrm{ppm}_{2} \mathrm{~S}$ along the thickness of the anode at $\mathrm{t}=20 \mathrm{~h}$ 


\subsubsection{Phosphine and Hydrogen Sulfide Mixture}

Next analysis investigates the effect of multi-component impurity including 5 ppm $\mathrm{PH}_{3}$ and $5 \mathrm{ppm} \mathrm{H}_{2} \mathrm{~S}$. Results obtained with different averaging techniques are given in Figure 5.31. As can be seen from the figure, mixture of impurities leads to lower cell performance than that of the lowest of two single impurity cases for all the averaging techniques utilized. In addition, when multiplication and weighted powers averaging methods were used the cell fails at around 60 hours whereas weighted average and harmonic average methods lead to a low value of stable power around that time of operation.

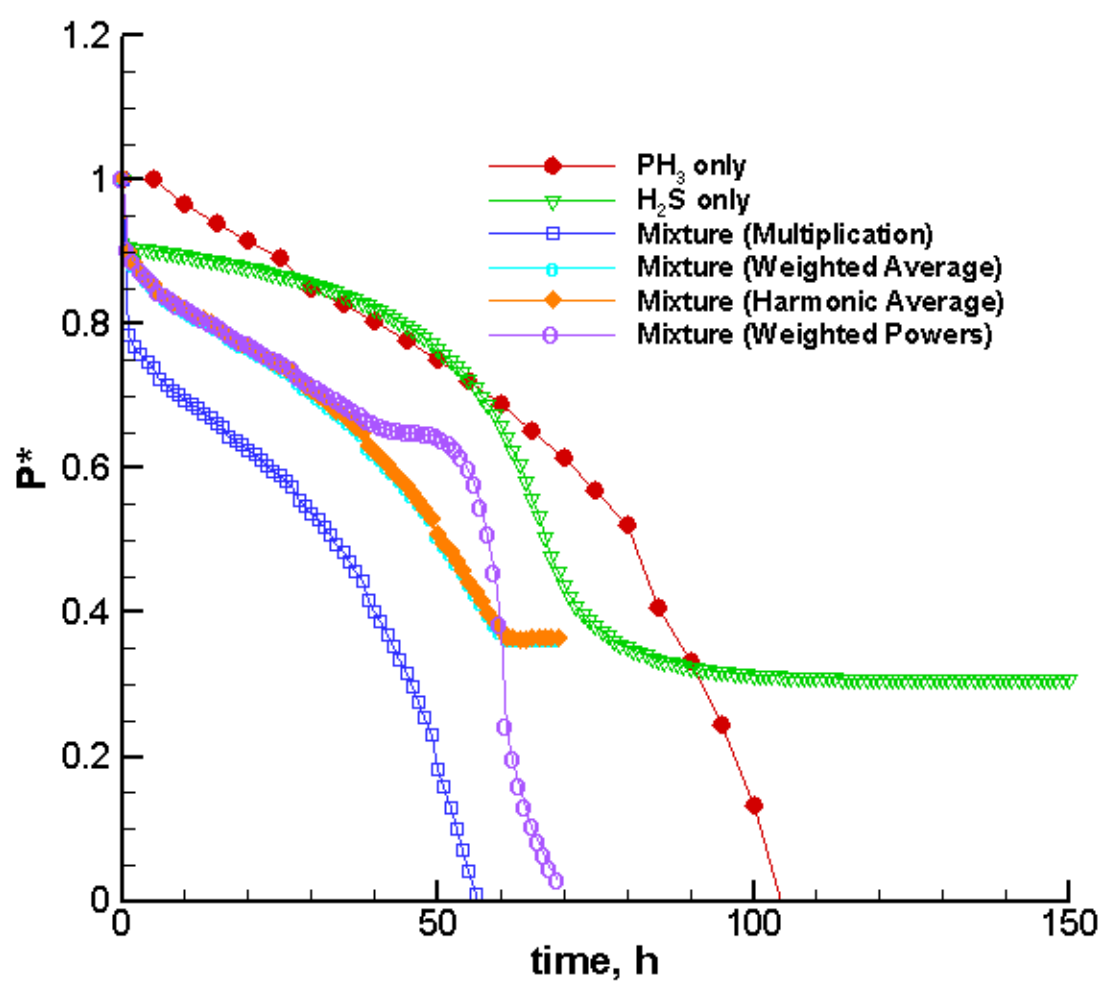

Figure 5. 31: Comparison of performance loss for a mixture of $5 \mathrm{ppm} \mathrm{PH}_{3}$ and $5 \mathrm{ppm}$ $\mathrm{H}_{2} \mathrm{~S}$ with different averaging techniques 


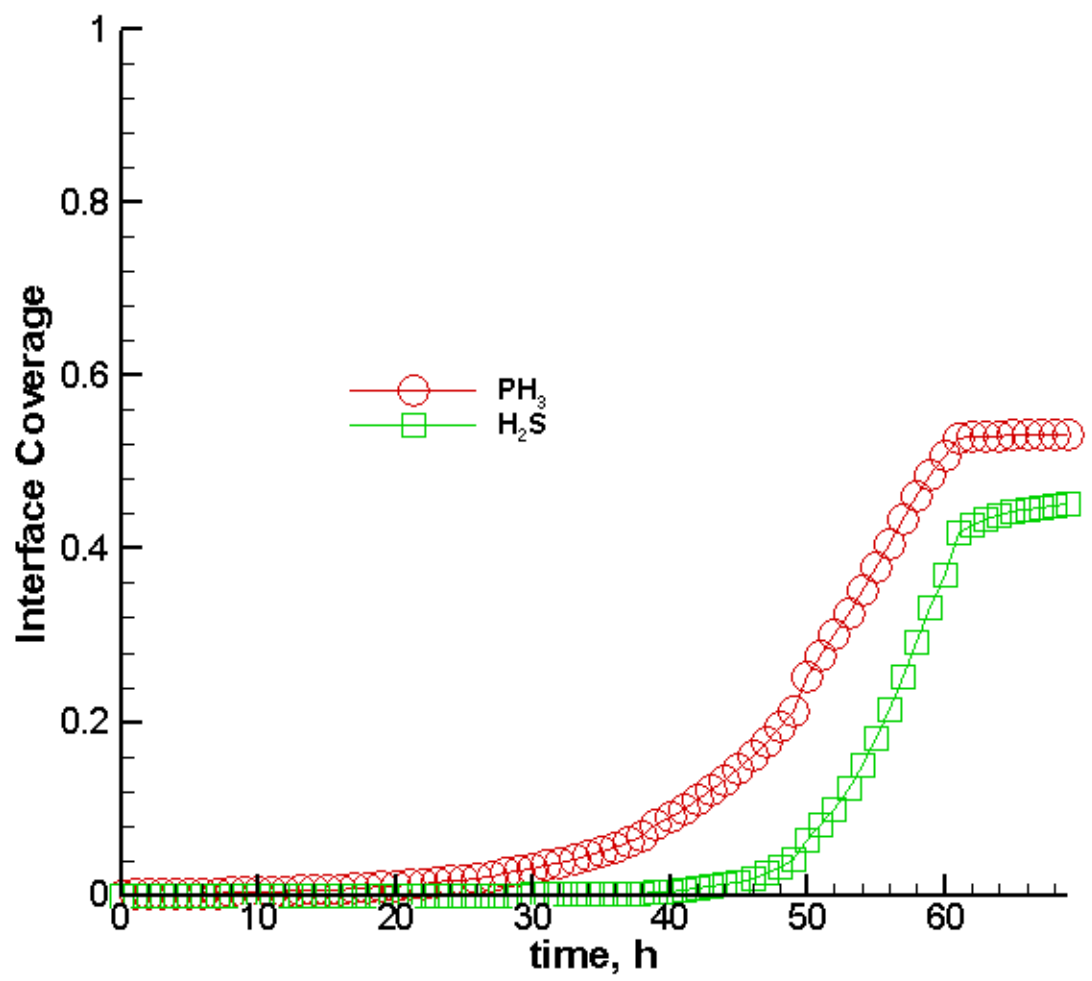

Figure 5. 32: Time evolution of interface coverages for $5 \mathrm{ppm} \mathrm{PH}_{3}$ and $5 \mathrm{ppm}_{2} \mathrm{~S}$

Figure 5.32 displays the time evolution of interface coverages for the phosphine and hydrogen sulfide impurities. As can be seen from the figure, the interface coverages reach their maximum possible values at around time $=60 \mathrm{~h}$. This time should be the time when the degradation curve either stabilizes at a lower value or fails. However, it was shown in the experiments performed for anode-supported cells that the performance does not exhibit a stabilized performance but it continues to degrade at a constant rate [17]. Therefore, degradation curves obtained by using multiplication or weighted powers techniques are more realistic compared to weighted average and harmonic average methods. Figure 5.32 also shows that the values of the interface coverages for both impurity species are similar with phosphine interface coverage being slightly higher. Concentration profiles along the thickness of the anode also show that the phosphine concentration is slightly higher. (see Figure 5.33) 


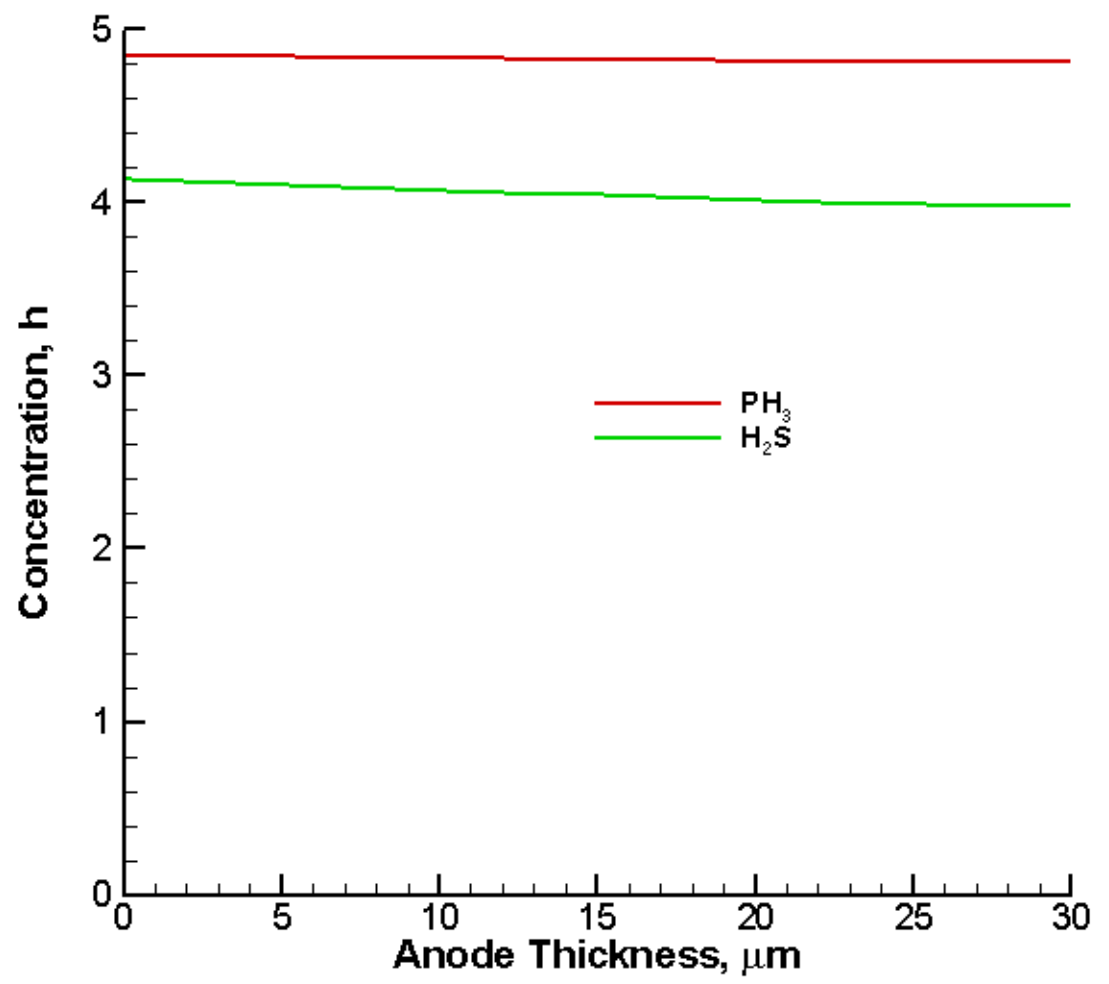

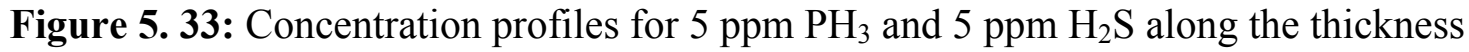
of the anode at $\mathrm{t}=50 \mathrm{~h}$

\subsubsection{Arsine Phosphine and Hydrogen Sulfide Mixture}

Finally, the synergistic effect of a mixture of three impurities including $5 \mathrm{ppm} \mathrm{PH}_{3}, 5 \mathrm{ppm}$ $\mathrm{H}_{2} \mathrm{~S}$ and $5 \mathrm{ppm} \mathrm{AsH}_{3}$ in a simulated syngas was investigated using the multiplication averaging technique and the result is given in Figure 5.34. 


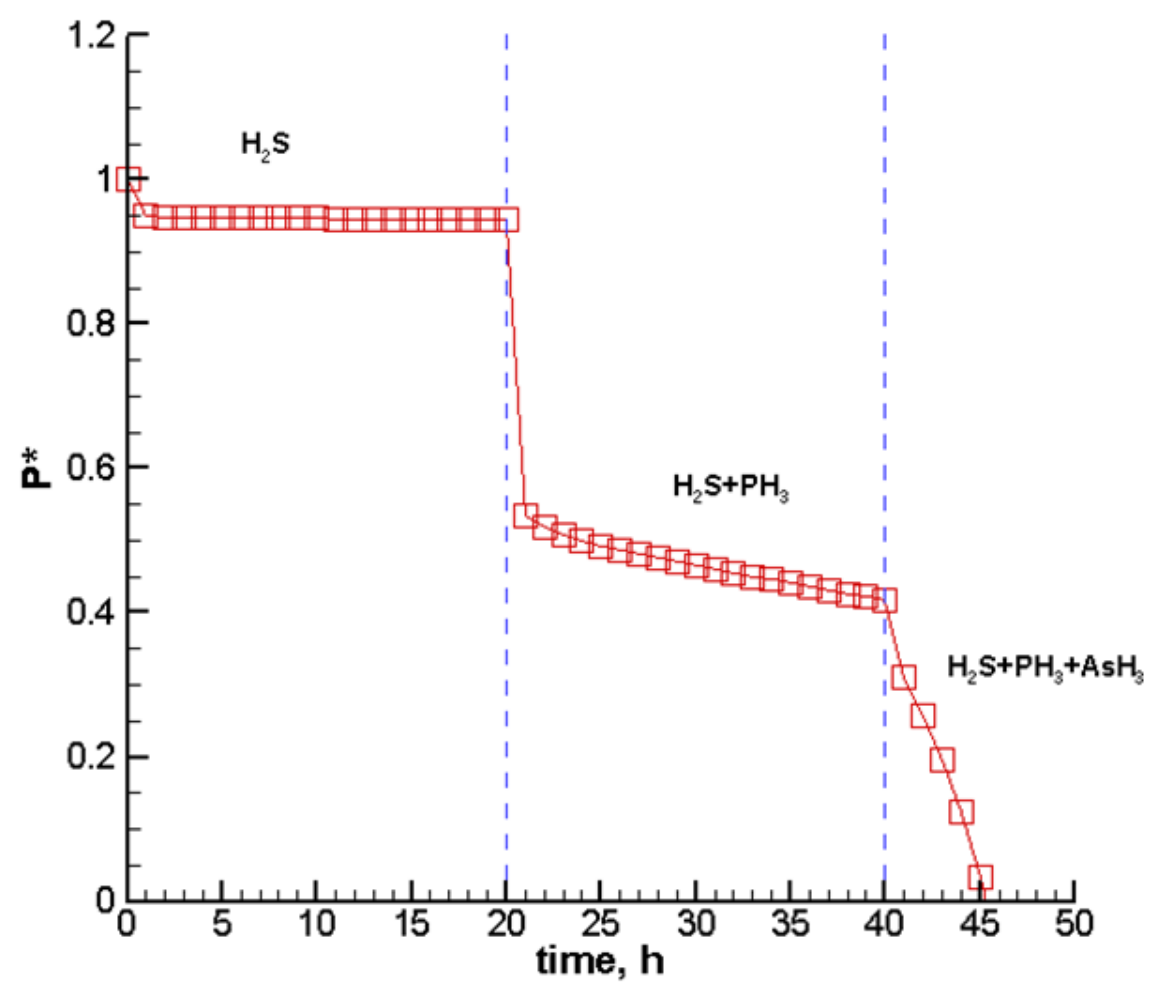

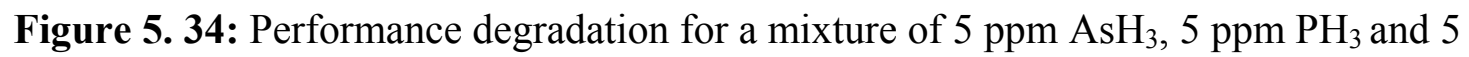
ppm $\mathrm{H}_{2} \mathrm{~S}$

It can be seen from the figure that addition of $5 \mathrm{ppm}$ phosphine on top $5 \mathrm{ppm}$ hydrogen sulfide results in a sudden initial performance loss of $40 \%$, however, the rate of degradation is rather slower for the next $20 \mathrm{~h}$ of operation. When $5 \mathrm{ppm}$ arsine is also added to the fuel, cell degrades rapidly and completely fails within 5 hours.

\subsection{Estimation of Tolerance Limits}

The ultimate goal of this study is to establish the minimum allowable impurity concentrations in coal syngas intended to be used in SOFCs operating for over 10,000 h. Arsine and phosphine are the two impurities that are known to have the most deleterious effects of the cell performance due to their affinity to have strong relations with the anode catalyst by formation of secondary phases. Numerically determined lifetimes of the cells can provide a basis for estimation of SOFC stack lifetimes operating on coal syngas. 
Extrapolation of accelerated results at relatively higher concentrations can provide guidance into predicting the cell failure at low impurity concentration.

A summary of cell lifetimes for electrolyte-supported cells with an anode thickness of 30 $\mu \mathrm{m}$ operated in simulated coal syngas containing $23 \% \mathrm{CO}, 30 \% \mathrm{H}_{2}, 21 \% \mathrm{CO}_{2}$ and $26 \%$ $\mathrm{H}_{2} \mathrm{O}$ and varying concentrations of $\mathrm{AsH}_{3}$ impurity is given in Figure 5.35. The criterion for cell failure is taken as the time when $60 \%$ of power loss occurs.

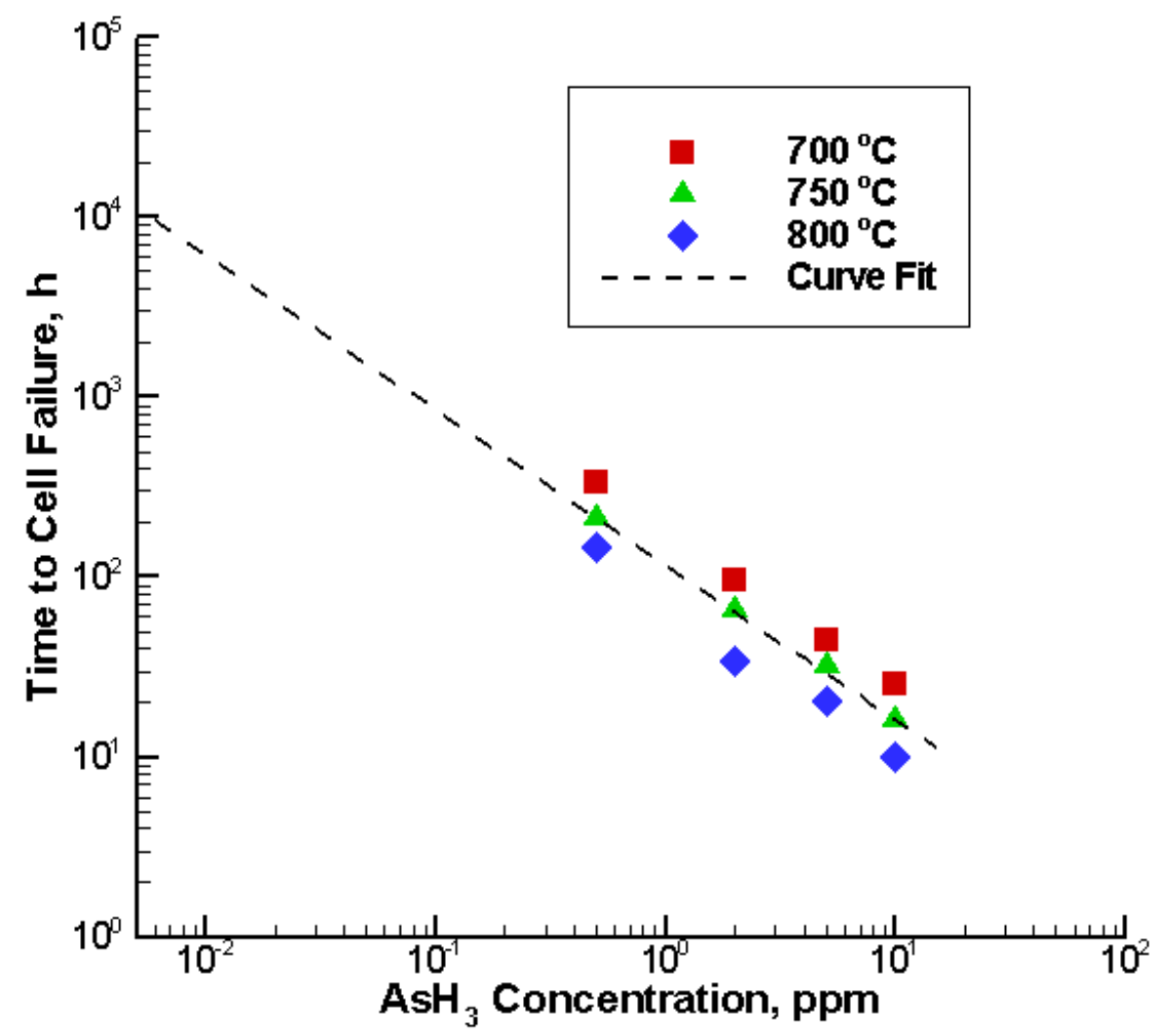

Figure 5. 35: Time to cell failure for electrolyte-supported cells exposed to simulated coal syngas with varying concentrations of arsine at different operating temperatures

As can be seen from the figure, a power law type of curve was fit to the numerical results at different temperatures. Extrapolation of the fitted curve to lower impurity concentrations shows that for $10,000 \mathrm{~h}$ of operation, the minimum allowable impurity 
concentration is estimated to be about $5 \mathrm{ppb}$. The closed form relation extracted from the numerical results for estimating the lifetime of electrolyte-supported cell can be given by:

$\mathrm{t}_{\text {failure }}=1.19 \times 10^{6}\left(\frac{C}{C_{r e f}}\right)^{-0.87}\left[1-3.48 \times 10^{-4}\left(\frac{T}{T_{\text {ref }}}\right)\right]$

where $C$ is the impurity concentration in ppm, $T$ is the operating temperature in ${ }^{\circ} \mathrm{C}$. Reference concentration, $C_{r e f}$, and reference temperature $T_{\text {ref }}$ are taken as $0.5 \mathrm{ppm}$ and $700{ }^{\circ} \mathrm{C}$, respectively.

In an attempt to include the anode thickness into the prediction of cell failure time more simulations were run for $10 \mathrm{ppm} \mathrm{AsH}_{3}$ in coal syngas at $800{ }^{\circ} \mathrm{C}$ the results are given in Figure 5.36. As it is seen from the figure, there is a linear relationship between the cell failure time and the anode thickness.

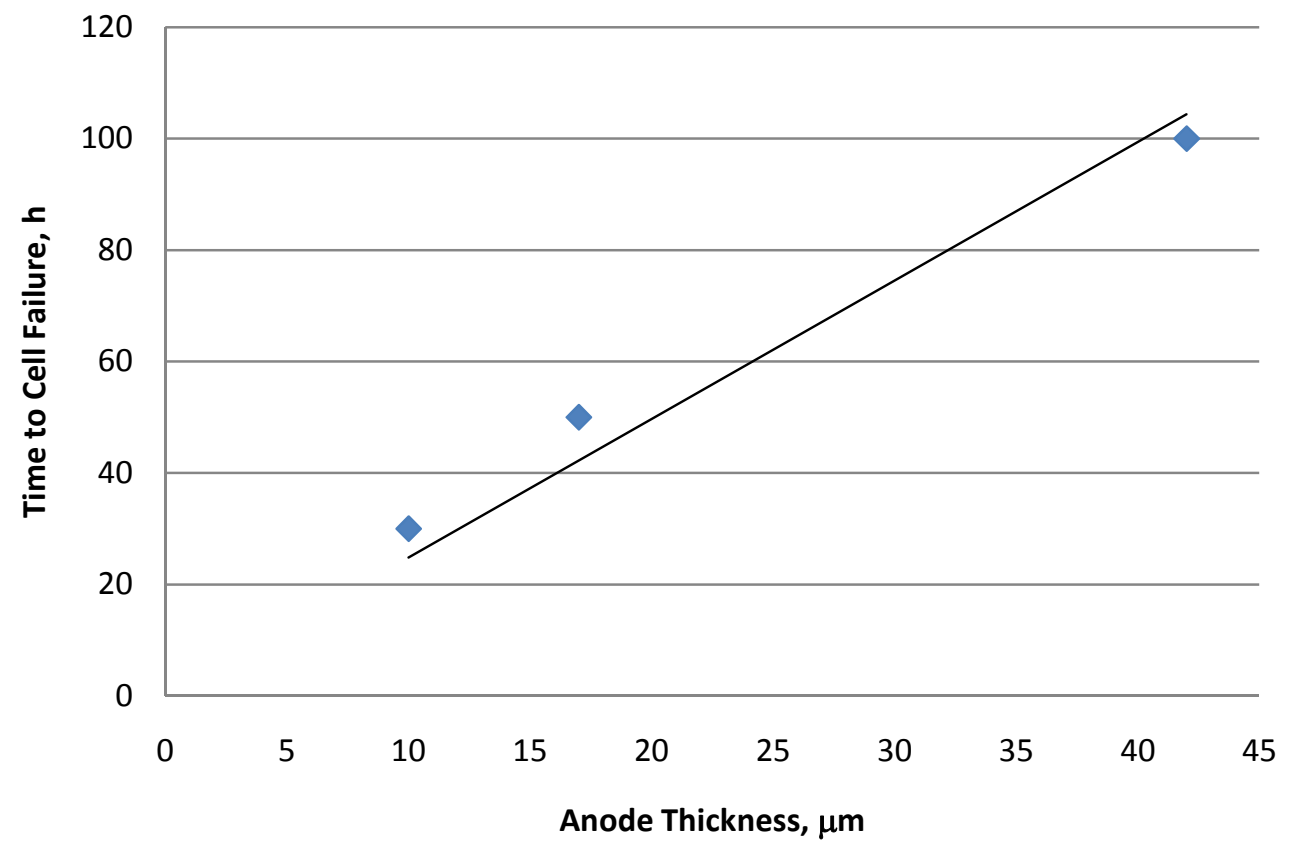

Figure 5. 36: Time to cell cells exposed to simulated coal syngas with $10 \mathrm{ppm}$ of $\mathrm{AsH}_{3}$ coal syngas at $800^{\circ} \mathrm{C}$ with varying anode thicknesses 
Similar analysis was done for phosphine using the same composition for the coal syngas. Figure 5.37 summarizes the cell failure times at different concentration of $\mathrm{PH}_{3}$. Since experiments show no dependence of cell performance on temperature for electrolytesupported cells, the analysis was done at one temperature of $800{ }^{\circ} \mathrm{C}$.

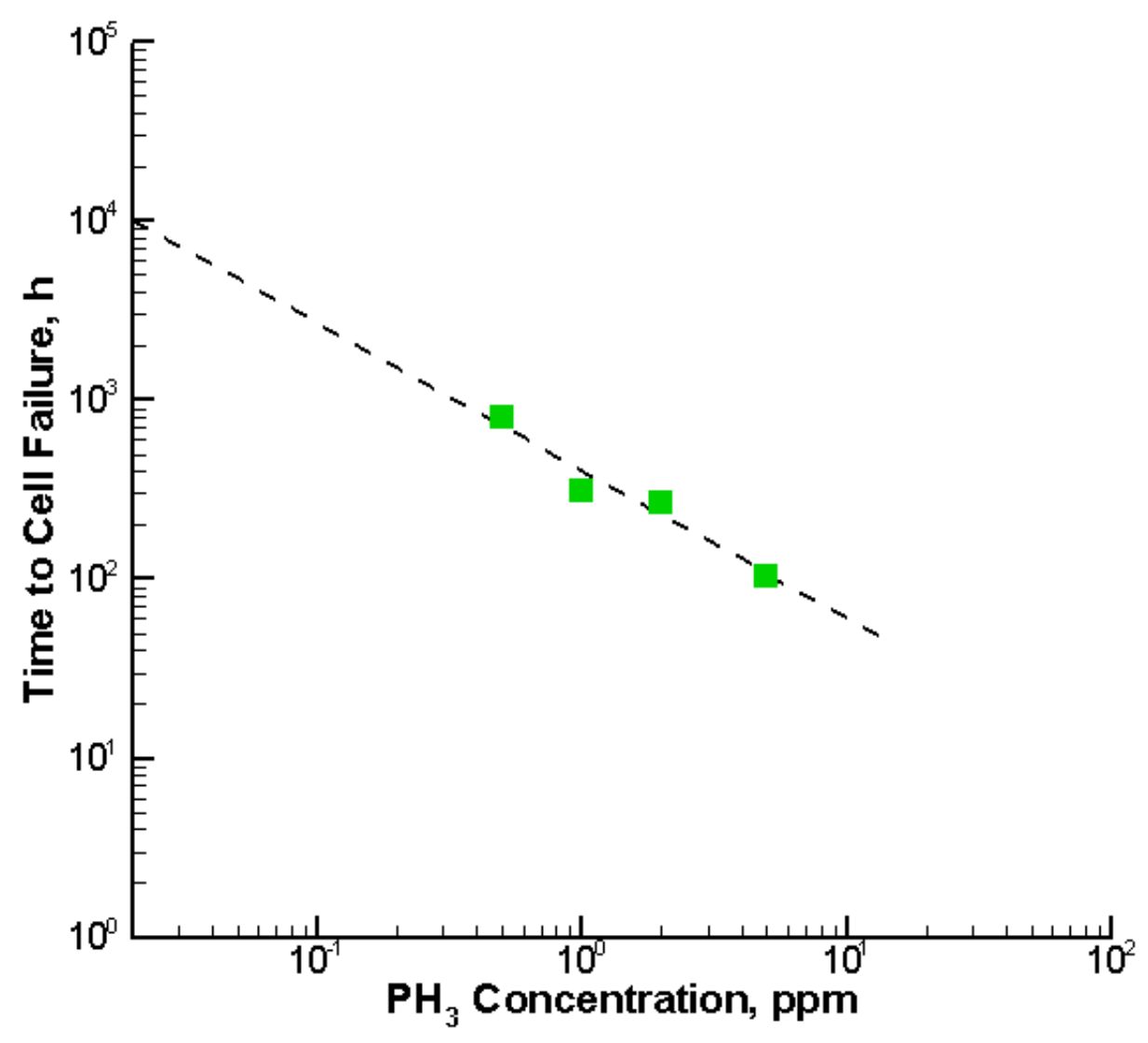

Figure 5. 37: Time to cell failure for electrolyte-supported cells exposed to simulated coal syngas with varying concentrations of phosphine at $800^{\circ} \mathrm{C}$

As can be seen from the figure, extrapolation of the power law type of curve fit to lower impurity concentrations shows that for $10,000 \mathrm{~h}$ of operation, the minimum allowable impurity concentration is estimated to be about $0.2 \mathrm{ppb}$. The closed form relation extracted from the numerical results for estimating the lifetime of electrolyte-supported cell can be given by: 
$\mathrm{t}_{\text {failure }}=7.15 \times 10^{2}\left(\frac{C}{C_{r e f}}\right)^{-0.83}$

Here again the cell failure time, $t_{\text {failure, }}$ was assumed to occur when $60 \%$ of the power is lost. 


\section{CHAPTER 6- CONCLUSIONS AND RECOMMENDATIONS}

\subsection{Conclusions}

- A new phenomenological model is formulated to predict the typical degradation patterns observed in SOFC anodes due to coal syngas impurities.

- Model parameters such as reaction rate constants for the adsorption reactions are obtained through indirect calibration to match the degradation rates reported in the literature for Arsine $\left(\mathrm{AsH}_{3}\right)$, Phosphine $\left(\mathrm{PH}_{3}\right)$, Hydrogen Sulfide $\left(\mathrm{H}_{2} \mathrm{~S}\right)$ under accelerated testing conditions

- Parametric studies performed at different impurity concentrations, operating temperatures and current densities showed that the coverage rate increases with increasing temperature and impurity concentration as expected.

- Calibrated model was then used for prediction of the performance curves at different impurity concentrations and operating temperatures. Encouraging agreement was obtained between the predicted results and the experimental data reported in the literature. 
- Synergistic effect of various impurities including $\mathrm{AsH}_{3}, \mathrm{PH}_{3}$ and $\mathrm{H}_{2} \mathrm{~S}$ was also examined and it was concluded that the mixture of impurities leads to faster degradation and thus shorter lifetime of the cell when compared to that of a single impurity.

\subsection{Future Work}

The model could be further advanced by incorporating the following aspects into it:

- The model can be extended to include the kinetics of formation of secondary phases with the anode material

- Modeling of nickel migration to the anode surface which is observed with impurity species forming secondary phases with the anode material can be incorporated

- Interactions of the impurities with LSM part of the anode which is shown to affect the performance degradation can also be included in the surface reaction mechanism

- A more advanced calibration technique can be utilized

- Model parameters to minimize the effect of experiments performed at different conditions can be included

- The developed degradation model can be included into a detailed multidimensional model for simulation of transport phenomena in SOFCs such as DREAM-SOFC

- A more sophisticated surface reaction mechanism for multiple impurities that allows for mutual interactions between various impurities can be incorporated. 


\section{REFERENCES}

1. http://www.eia.doe.gov, date accessed: November 15, 2010.

2. S.C. Singhal, 2003, High-Temperature Solid Oxide Fuel Cells Fundamentals, Design and Applications, Elsevier.

3. X. Li, 2006, Principles of Fuel Cells, New York, Taylor \& Francis Group.

4. C. Higman and M. van der Burgt, 2003, Gasification, New York, Elsevier.

5. J. Ratafia-Brown, L. Manfredo, J. Hoffmann, and M. Ramezzan (2002) "Major environmental aspects of gasification-based power generation technologies," U.S. Department of Energy, Morgantown.

6. J.P. Trembly, R.S. Gemmen, and D.J. Bayless, (2007) "The effect of IGFC warm gas cleanup system conditions on the gas-solid partitioning and form of trace species in coal syngas and their interactions with SOFC anodes," Journal of Power Sources, Vol. 163, pp. 986-996.

7. NETL, 2004, Fuel Cell Handbook, $7^{\text {th }}$ Ed.

8. G.N. Krishnan (2006) "Effect of coal contaminants on solid oxide fuel system performance and service life," SRI International, Morgantown.

9. T. Kivisaari, P. Bjornbom, C. Sylwan, B. Jacquinot, D. Jansen, and A. de Groot, (2004) "The feasibility of a coal gasifier combined with a high-temperature fuel cell," Chemical Engineering Journal, Vol. 100, pp. 167-180.

10. Y. Yi, A.D. Rao, J. Brouwer, and G.S. Samuelsen, (2005) "Fuel flexibility study of an integrated $25 \mathrm{~kW}$ SOFC reformer system," Journal of Power Sources, Vol. 144, pp. 67-76.

11. A. Verma, A.D. Rao, and G.S. Samuelsen, (2006) "Sensitivity analysis of a vision 21 coal based zero emission power plant," Journal of Power Sources, Vol. 158, pp. 417-427.

12. Y. Matsuzaki and I. Yasuda, (2000) "The poisoning effect of sulfur-containing impurity gas on a SOFC anode: Part I. Dependence on temperature, time and impurity concentration," Solid State Ionics, Vol. 132, pp. 261-269. 
13. J.P. Trembly, A.I. Marquez, T.R. Ohrn, and D.J. Bayless, (2006) "Effects of coal syngas and $\mathrm{H}_{2} \mathrm{~S}$ on the performance of solid oxide fuel cells: Single-cell tests," Journal of Power Sources, Vol. 158, pp. 263-273.

14. A.I. Marquez, T.R. Ohrn, J.P. Trembly, D.C. Ingram, and D.J. Bayless, (2007) "Effects of coal syngas and $\mathrm{H} 2 \mathrm{~S}$ on the performance of solid oxide fuel cells Par 2. Stack tests," Journal of Power Sources, Vol. 164, pp. 659-667.

15. S.C. Singhal and K. Kendall, 2002, High Temperature Solid Oxide Fuel Cells, Oxford, UK, Elsevier.

16. J. Bao, G.N. Krishnan, P. Jayaweera, J. Perez-Mariano, and A. Sanjurjo, (2009) "Effect of various coal contaminants on the performance of solid oxide fuel cells: Part I. Accelerated testing," Journal of Power Sources, Vol. 193, pp. 607-616.

17. J. Bao, G.N. Krishnan, P. Jayaweera, and A. Sanjurjo, (2010) "Effect of various coal contaminants on the performance of solid oxide fuel cells: Part III. Synergistic effects," Journal of Power Sources, Vol. 195, pp. 1316-1324.

18. J.P. Trembly, R.S. Gemmen, and D.J. Bayless, (2007) "The effect of coal syngas containing $\mathrm{AsH}_{3}$ on the performance of SOFCs: Investigations into the effect of operational temperature, current density and $\mathrm{AsH}_{3}$ concentration," Journal of Power Sources, Vol. 171, pp. 818-825.

19. J.P. Trembly, R.S. Gemmen, and D.J. Bayless, (2007) "The effect of coal syngas containing $\mathrm{HCl}$ on the performance of solid oxide fuel cells: Investigations into the effect of operational temperature and $\mathrm{HCl}$ concentration," Journal of Power Sources, Vol. 169, pp. 347-354.

20. J.P. Trembly, R.S. Gemmen, and D.J. Bayless, The effect of trace As, Cl, P and Se coal syngas species on the performance of a planar solid oxide fuel cell, in FuelCell07 Fifth Fuel Cell Science, Engineering and Technology Conference, New York, NY, June 18-20, 2007.

21. O.A. Marina, L.R. Pederson, C.A. Coyle, E.C. Thomsen, D.J. Edwards, C.D. Nguyen, and G.W. Coffey, Interactions of Ni/YSZ anodes with coal gas contaminants, in 9th Annual SECA Workshop. August 7, 2008: Pittsburgh, PA.

22. C.A. Coyle, O.A. Marina, E.C. Thomsen, D.J. Edwards, C.D. Cramer, G.W. Coffey, and L.R. Pederson, (2009) "Interactions of nickel/zirconia solid oxide fuel 
cell anodes with coal gas containing arsenic," Journal of Power Sources, Vol. 193, pp. 730-738.

23. O.A. Marina, C.A. Coyle, E.C. Thomsen, D.J. Edwards, G.W. Coffey, and L.R. Pederson, (2010) "Degradation mechanisms of SOFC anodes in coal gas containing phosphorous," Solid State Ionics, Vol. 181, pp. 430-440.

24. C. Xu, M. Gong, J.W. Zondlo, X. Liu, and H.O. Finklea, (2010) "The effect of $\mathrm{HCl}$ in syngas on Ni-YSZ anode-supported solid oxide fuel cells," Journal of Power Sources, Vol. 195, pp. 2149-2158.

25. C. Xu, J.W. Zondlo, H.O. Finklea, O. Demircan, M. Gong, and X. Liu, (2009) "The effect of phosphine in syngas on Ni-YSZ anode-supported solid oxide fuel cells," Journal of Power Sources, Vol. 193, pp. 739-746.

26. M. Zhi, F.N. Cayan, I. Celik, R. Gemmen, S.R. Pakalapati, and N.Q. Wu, (2010) "Temperature and impurity concentration effects on degradation of nickel/yttriastabilized zirconia anode in $\mathrm{PH}_{3}$-containing coal syngas," Fuel Cells, Vol. 10, pp. 174-180.

27. M. Zhi, X. Chen, H. Finklea, I. Celik, and N.Q. Wu, (2008) "Electrochemical and microstructural analysis of nickel/yttria-stabilized zirconia electrode operated in phosphorus-containing syngas," Journal of Power Sources, Vol. 183, pp. 485-490.

28. M. Diaz-Somoano and M.R. Tarazona, (2003) "Trace element evaporation during coal gasification based on a thermodynamic equilibrium calculation approach," Fuel, Vol. 82, pp. 137-145.

29. J.P. Trembly, R.S. Gemmen, and D.J. Bayless, (2007) "The effect of IGFC warm gas cleanup system conditions on the gas-solid partitioning and form of trace species in coal syngas and their interactions with SOFC anodes," Journal of Power Sources, Vol. 163, pp. 986-996.

30. J.J. Helble, W. Mojtahedi, J. Lyyranen, J. Jokiniemi, and E. Kauppinen, (1996) "Trace element partitioning during coal gasification," Fuel, Vol. 75, pp. 931-939.

31. G.N. Krishnan (2006) "Effect of coal contaminants on solid oxide fuel system performance and service life, Technical progress report 1," SRI International, Morgantown. 
32. G.N. Krishnan (2006) "Effect of coal contaminants on solid oxide fuel system performance and service life," SRI International, Morgantown.

33. A. Martinez, K. Gerdes, R. Gemmen, and J. Poston, (2010) "Thermodynamic analysis of interactions between Ni-based solid oxide fuel cells (SOFC) anodes and trace species in a survey of coal syngas," Journal of Power Sources, Vol. 195, pp. 5206-5212.

34. T. Ackmann, L.G. de Haart, and D. Stolten, Modeling of Mass Transport in Planar Substrate Type SOFCs, in Fifth European Solid Oxide Fuel Cell Forum, Lucern, Switzerland, 2002.

35. W. Lehnert, J. Meusinger, and F. Thom, (2000) "Modeling of transport phenomena in SOFC anodes," Journal of Power Sources, Vol. 87, pp. 57-63.

36. W. Drescher, W. Lehnert, and J. Meusinger, (1998) "Structural properties of SOFC anodes and reactivity," Electrochimical Acta, Vol. 43, pp. 3059.

37. B.A. Haberman and J.B. Young, (2004) "Three-dimensional simulation of chemically reacting gas flows in the porous support structure of an integratedplanar solid oxide fuel cell," International Journal of Heat and Mass Transfer, Vol. 47, pp. 3617-3629.

38. E.S. Hecht, G.K. Gupta, H. Zhu, A.M. Dean, R.J. Kee, L. Maier, and O. Deutschmann, (2005) "Methane reforming kinetics within a Ni-YSZ SOFC anode support," Applied Catalysis A: General, Vol. 295, pp. 40-51.

39. R.S. Gemmen and J. Trembly, (2006) "On the mechanisms and behavior of coal syngas transport and reaction within the anode of a solid oxide fuel cell," Journal of Power Sources, Vol. 161, pp. 1084-1095.

40. R. Suwanwarangkul, E. Croiset, M.W. Fowler, P.L. Douglas, E. Entchev, and M.A. Douglas, (2003) "Performance comparison of Fick's, dusty-gas and StefanMaxwell models to predict the concentration overpotential of a SOFC anode," Journal of Power Sources, Vol. 122, pp. 9-18.

41. R. Suwanwarangkul, E. Croiset, E. Entchev, S. Charojrochkul, M.D. Pritzker, M.W. Fowler, P.L. Douglas, S. Chewathanakup, and H. Mahaudom, (2006) "Experimental and modeling study of solid oxide fuel cell operating with syngas fuel," Journal of Power Sources, Vol. 161, pp. 308-322. 
42. J.B. Hansen, (2008) "Correlating sulfur poisoning of SOFC nickel anodes by a Temkin isotherm," Electrochemical and Solid-State Letters, Vol. 11, pp. B178B180.

43. J. Zhang, H. Wang, D.P. Wilkinson, D. Song, J. Shen, and Z. Liu, (2005) "Model for the contamination of fuel cell anode catalyst in the presence of fuel stream impurities," Journal of Power Sources, Vol. 147, pp. 58-71.

44. D. Sarantaridis and A. Atkinson, (2007) "Redox cycling of Ni-based solid oxide fuel cell anodes: A review," Fuel Cells, Vol. 7, pp. 246-258.

45. G. Iqbal, H. Guo, B. Kang, and O. Marina, (2009) "Durability prediction of solid oxide fuel cell anode material under thermomechanical and fuel gas contaminant effects," International Journal of Applied Ceramic Technology, Vol. pp. doi: 10.1111/j.1744-7402.2009.02415.x.

46. http://sourceforge.net/projects/cantera/, date accessed: November 15, 2010.

47. W.R. Smith and R.W. Missen, 1982, Chemical Reaction Equilibrium Analysis: Theory and Algorithms, New York, Wiley Inter Science.

48. M. Binnewies and E. Milke, 2002, Thermochemical Data of Elements and Compounds, 2nd Ed., New York, Wiley Inter Science.

49. http://webbook.nist.gov, date accessed: November 10, 2010.

50. H. Kishimoto, K. Yamaji, M.E. Brito, T. Horita, and H. Yokokawa, (2008) "Generalized Ellingham diagrams for utilization in solid oxide fuel cells," Journal of Mining and Metallurgy, Vol. 44B, pp. 39-48.

51. D.L. Hildenbrand and K.H. Lau, (1994) "Thermochemical properties of gaseous $\mathrm{POBr}$ and some H-P-O species," Journal of Chemical Physics, Vol. 100, pp. 8373-8376.

52. O. Demircan, W. Zhang, C. Xu, J. Zondlo, and H.O. Finklea, (2010) "The effect of overpotential on performance degradation of the solid oxide fuel cell Ni/YSZ anode during exposure to syngas with phosphine contaminant," Journal of Power Sources, Vol. 195, pp. 3091-3096.

53. W. Liu, X. Sun, L.R. Pederson, O.A. Marina, and M.A. Khaleel, (2010) "Effect of nickel-phosphorous interactions on structural integrity of anode supported solid oxide fuel cells," Journal of Power Sources, Vol. 195, pp. 7140-7145. 
54. O.A. Marina, C.A. Coyle, E.C. Thomsen, D.J. Edwards, G.W. Coffey, and L.R. Pederson, (2010) "Degradation mechanism of SOFC anodes in coal gas containing phosphorous," Solid State Ionics, Vol. 181, pp. 430-440.

55. S.H. Chan, K.A. Khor, and Z.T. Xia, (2001) "A complete polarization model of a solid oxide fuel cell and its sensitivity to the change of fuel cell component thickness," Journal of Power Sources, Vol. 93, pp. 130-140.

56. J.R. Ferguson, J.M. Fiard, and R. Herbin, (1996) "Three-dimensional numerical simulation for various geometries of solid oxide fuel cells," Journal of Power Sources, Vol. 58, pp. 109-122.

57. H. Yakabe, M. Hishinuma, M. Uratani, Y. Matsuzaki, and I. Yasuda, (2000) "Evaluation and modeling of performance of anode-supported solid oxide fuel cells," Journal of Power Sources, Vol. 86, pp.

58. D. Sanchez, R. Chacartegui, A. Munoz, and T. Sanchez, (2006) "Thermal and electrochemical model of internal reforming solid oxide fuel cells with internal reforming," Journal of Power Sources, Vol. 160, pp. 1074-1087.

59. R. Krishna and J.A. Wesselingh, (1997) "The Maxwell-Stefan approach to mass transfer," Chemical Engineering Science, Vol. 52, pp. 861-911.

60. E.A. Mason and A.P. Malinauskas, 1983, Gas transport in porous media: The dusty gas model, New York, Elsevier.

61. E.L. Cussler, 1997, Diffusion mass transfer in fluid systems, $2^{\text {nd }}$ Ed., Cambridge, UK, Cambridge University Press.

62. R.B. Bird, W.E. Stewart, and E.N. Lightfoot, 2001, Transport Phenomena, $2^{\text {nd }}$ Ed., New York, John Wiley \& Sons.

63. W. Lehnert, J. Meusinger, and F. Thom, (2000) "Modeling of gas transport phenomena in SOFC anodes," Journal of Power Sources, Vol. 87, pp. 57-63.

64. B.A. Haberman and J.B. Young, (2004) "Three-dimensional simulation of chemical reacting gas flows in the porous support structure of an integrated planar solid oxide fuel cell," International Journal of Heat and Mass Transfer, Vol. 47, pp. 3617-3629. 
65. R.S. Gemmen and J. Trembly, (2006) "On the mechanism and behavior of coal syngas transport and reaction within the anode of a solid oxide fuel cell," Journal of Power Sources, Vol. 161, pp. 1084-1095.

66. S.R. Pakalapati, F. Elizalde-Blancas, and I. Celik, Modeling of a coal syngas based SOFC, in Coal Based Fuel Cell Technology: Status, Needs and Future Applications, Morgantown, WV, October 11-12, 2007.

67. F. Elizalde-Blancas, S.R. Pakalapati, J.A. Escobar-Vargas, and I.B. Celik, Numerical evaluation and comparison of different reduced mechanisms for predicting the performance of a SOFC operating on coal syngas, in 2008 ASME Fluids Engineering Division Summer Conference, Jacksonville, FL, 2008.

68. F.N. Cayan, S.R. Pakalapati, F. Elizalde-Blancas, and I. Celik, (2009) "On modeling multi-component diffusion inside the porous anode of solid oxide fuel cells using Fick's model," Journal of Power Sources, Vol. 192, pp. 467-474.

69. J.W. Zondlo and C. Xu, Private Communication. 2008.

70. R.E. Williford, L.A. Chick, G.D. Maupin, S.P. Simner, and J.W. Stevenson, (2003) "Diffusion limitations in the porous anodes of SOFCs," Journal of Electrochemical Society, Vol. 150, pp. A1067-A1072.

71. J.R. Izzo, A.A. Peracchio, and W.K.S. Chiu, (2008) "Modeling of gas transport through a tubular solid oxide fuel cell and porous anode layer," Journal of Power Sources, Vol. 176, pp. 200-206.

72. Y. Jiang and A.V. Virkar, (2003) "Fuel composition and diluent effect on gas transport and performance of anode-supported SOFCs," Journal of Electrochemical Society, Vol. 150, pp. A942-A951.

73. A.V. Virkar (2003) "Low-temperature anode-supported high power density solid oxide fuel cells with nanostructured electrodes," University of Utah, Contract No: AC26-99FT40713.

74. Y. Shi, N. Cai, and C. Li, (2007) "Numerical modeling of anode-supported SOFC button cell considering anodic surface diffusion," Journal of Power Sources, Vol. 164, pp. 639-648. 
75. J.P. Trembly, A.I. Marquez, T.R. Ohrn, and D.J. Bayless, (2006) "Effects of coal syngas and $\mathrm{H}_{2} \mathrm{~S}$ on the performance of solid oxide fuel cells: Single-cell tests," Journal of Power Sources, Vol. 158, pp. 263-273.

76. O.A. Marina, L.R. Pederson, D.J. Edwards, C.W. Coyle, J. Templeton, M. Engelhard, and Z. Zhu, SOFC operation on hydrogen and coal gas in the presence of phosphorous, arsenic and sulfur impurities, in 8th Annual SECA Workshop, San Antonio, TX, 2007.

77. G. Krishnan, Effect of coal contaminants on SOFC cell performance, in 8th Annual SECA Review Workshop, San Antonio, TX, 2007.

78. M. Zhi, X. Chen, H. Finklea, I. Celik, and N.Q. Wu, (2008) "Electrochemical and microstructural analysis of nickel-yttria-stabilized zirconia electrode operated in phosphorus-containing syngas," Journal of Power Sources, Vol. 183, pp. 485-490.

79. F.N. Cayan, M. Zhi, S.R. Pakalapati, I. Celik, N. Wu, and R. Gemmen, (2008) "Effects of coal syngas impurities on anodes of solid oxide fuel cells," Journal of Power Sources, Vol. 185, pp. 595-602.

80. M.C. Williams, J. Strakey, and W. Surdoval, (2006) "U.S. DOE fossil energy fuel cells program," Journal of Power Sources, Vol. 159, pp. 1241-1247.

81. O.A. Marina, L.R. Pederson, D.J. Edwards, C.W. Coyle, J. Templeton, M. Engelhard, and Z. Zhu, SOFC operation on hydrogen and coal gas in the presence of phosphorous, arsenic and sulfur impurities, in 8th Annual SECA Workshop, San Antonio, TX, 2007.

82. V.M. Janardhanan and O. Deutschmann, (2006) "CFD analysis of a solid oxide fuel cell with internal reforming: Coupled interactions of transport, heterogeneous catalysis and electrochemical processes," Journal of Power Sources, Vol. 162, pp. 1192-1202.

83. F. Elizalde-Blancas, Modeling Issues for Solid Oxide Fuel Cells Operating with Coal Syngas, Ph.D. Thesis, West Virginia University, Mechanical Engineering, Morgantown, 2009.

84. C.Xu, Personal Communication. 2010. 


\section{APPENDIX A}

\section{Effect of Using Different Numerical Time Steps on Equilibrium Concentration of $\mathrm{Ni}_{5} \mathbf{P}_{2}$}

The assumption of using a numerical time step of $1 \mathrm{sec}$ in the transient equilibrium calculations was justified by repeating calculations at $750{ }^{\circ} \mathrm{C}$ and $1 \mathrm{~atm}$ using an initial $\mathrm{PH}_{3}$ concentration of $5 \mathrm{ppm}$ and a current of $0.5 \mathrm{~A}$ using a numerical time step of $10 \mathrm{sec}$. It should be noted that as a numerical limitation of Cantera 1.7, any time step smaller than $1 \mathrm{sec}$ was not able to be used.

Figure A.1 shows the comparison between the percentage of nickel converted to nickel phosphide results obtained by using numerical time steps of $1 \mathrm{sec}$ and $10 \mathrm{sec}$. It can be seen that the results do not change when a time step of $10 \mathrm{~s}$ is used which means $1 \mathrm{~s}$ is enough for equilibrium. 


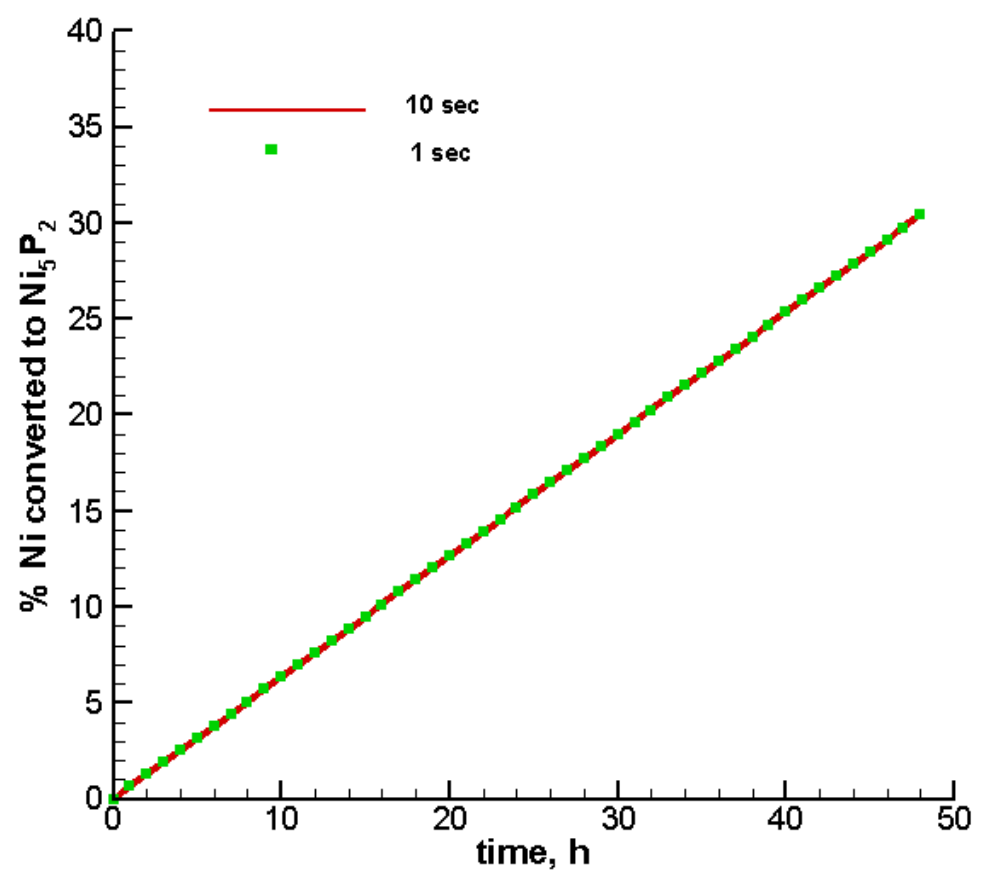

Figure A 1: Effect of using a numerical time step of $10 \mathrm{sec}$ on $\% \mathrm{Ni}$ converted to $\mathrm{Ni}_{5} \mathrm{P}_{2}$ 


\section{APPENDIX B}

\section{Calculation of Cathode Losses}

Oxygen activation overpotential is simply calculated from Butler-Volmer equation with the assumption that the transfer coefficient $\alpha$ is 0.5

$\eta_{a c t, O_{2}}=\frac{R_{u} T}{2 \alpha F} \sinh ^{-1}\left(\frac{i_{O_{2}}}{2 i_{o, O_{2}}}\right)$

where $i_{\mathrm{O}_{2}}$ is the current density. Oxygen exchange current density is given by

$i_{o, O_{2}}=\frac{c_{3}}{(T-279.1757)^{1 / 2}}\left(\frac{y_{O_{2}, \text { int }}}{y_{O_{2}, \text { ref }}}\right) \exp \left(-\frac{E_{a c t, O_{2}}}{R_{u} T}\right)$

where the reference oxygen concentration, $y_{O_{2}, \text { ref }}$, is 0.21 , the activation energy barrier, $E_{a c t, O_{2}}$, is $120 \mathrm{~kJ} / \mathrm{mol}$, and the constant $c_{3}$ is $5.874 \times 10^{9}[83]$. 